\title{
Phylogeography of the New Zealand whelks Cominella maculosa and $C$. virgata
}

\author{
Kerry Walton
}

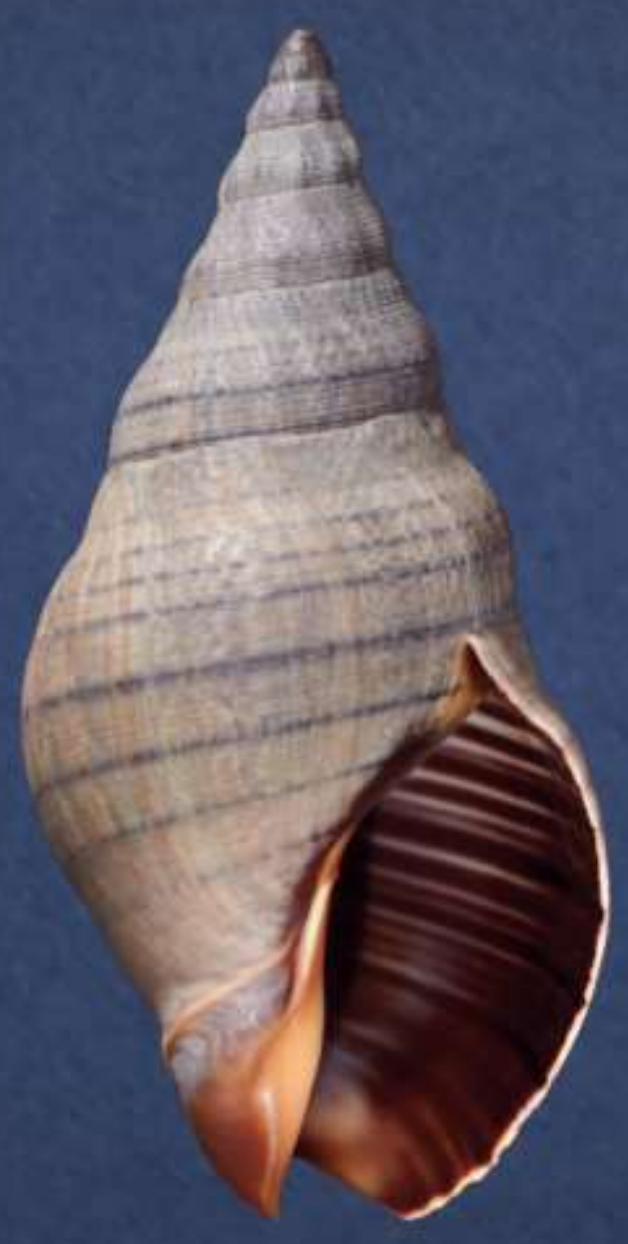

A thesis submitted to Victoria University of Wellington in partial fulfilment of the requirements for the degree of Master of Science in Marine Biology 
"Reality is frequently inaccurate"

- Douglas Adams 


\section{Acknowledgements}

A thesis is no minor undertaking and this work was only possible with the help and support of many people to whom I am immensely grateful. My partner Meredith Buchholz must top this list as her patience and support have been invaluable.

Next, my supervisors: Peter Ritchie and Nicole Phillips. I really valued their comments and the freedom they gave me to explore tangents and work at my own pace. Pete especially was always available for support, banter and some friendly joshing.

Bruce Marshall has been a fantastic friend and mentor, and a wealth of knowledge and advice. I am extremely thankful for his comments and assistance with libraries, taxonomy and museum collections, as well as for sharing many a glass of wine.

I really valued comments from Bruce Hayward on the geography of the Auckland Isthmus, and the various museum staff around the world who have assisted with type material (listed in Chapter 2).

My lab-mates too have been fantastic. First and foremost is Alex Verry who has endured my frustrations and soothed them with beer and coffee, and assisted with things involving computers or numbers. A big thank you to Melanie Dohner who was very patient showing me the lab techniques. Thanks also to Angela Fleming and Balam Jiminez Brito for answering questions.

Cécile Massiot has been exceptionally silly and exceptional company. Thanks too to the many other good sorts of the VUWTC (hi Marc and Kieran), our flatmates Nathan Trusty and Sarah McNab, and their dumb cat, for support and distraction.

For the many published sequences on GenBank, a big thank you to the authors of Donald et al. (2015). For contributing samples for this study, many thanks to Kevin and Judy Burch, Kathy Carson, Pete and Dee Cresswell, Derrick and Ann Crosby, Kevin and Yvonne Mead, Jason Plaisted, Marc Sykes and Mike and Sue Young. 


\section{Abstract}

Cominella maculosa and C. virgata are common rocky shore whelk species from New Zealand. This study used DNA sequences from the mitochondrial gene cytochrome $\mathrm{c}$ oxidase subunit $1(\mathrm{CO} 1)$ to expand an earlier unpublished dataset and examine the phylogeographic structure of both species in the Cook Strait region, of C. maculosa in the Chatham Islands, and of $C$. virgata in the northern North Island. Both species are found to have a considerable degree of phylogeographic structure, concordant with that reported by an earlier study and for other species with direct development.

South Island sites sampled for C. maculosa had several private haplotypes and a high frequency haplotype that is shared with populations from the southern North Island. Together, these formed a 'southern haplogroup'. Low diversity in 'southern' populations may reflect founder effects that would have occurred as part of a southward range expansion during the onset of the present interglacial period. The Chatham Islands samples had two haplotypes that formed a separate sub-group to the 'southern haplogroup', suggesting Chatham Islands populations are moderately isolated from those on mainland New Zealand but may have been founded from 'southern' populations relatively recently.

The high frequency haplotype present in South Island samples of C. virgata is absent in Wellington samples but widespread in those from the north-eastern North Island. South Island populations may have been founded from the Hauraki Gulf through human-mediated translocation events. Phylogenetic analyses with a focus on $C$. virgata were conducted using the mitochondrial genes CO1 and 16SrRNA, and the nuclear gene $18 \mathrm{~S}$ rRNA, to expand an earlier published dataset. The purported northern subspecies $C$. virgata brookesi does not form a monophyletic lineage and voucher specimens fluidly intergrade with the nominal subspecies, with which it is synonymised. A lectotype is designated for Buccinum lineolatum Quoy \& Gaimard, 1833, for which Cominella virgata is a replacement name. Potential causes of the disjunct distribution patterns of $C$. virgata and other mollusc taxa are discussed with particular reference to the formation and timing of marine straits through the Auckland Isthmus and Cook Strait. 


\section{Contents}

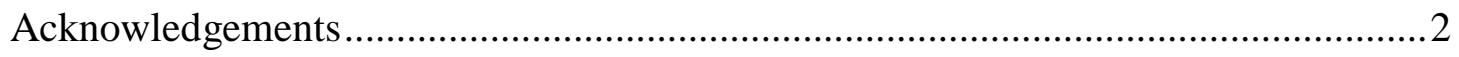

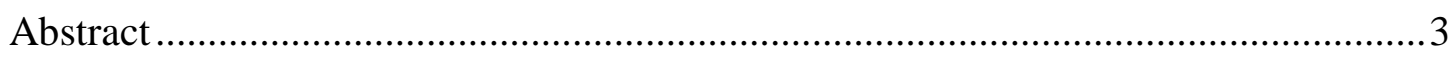

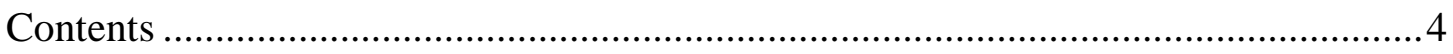

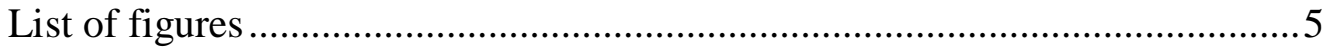

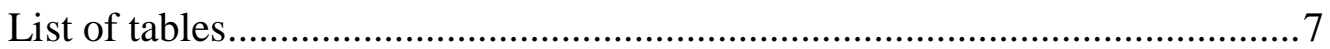

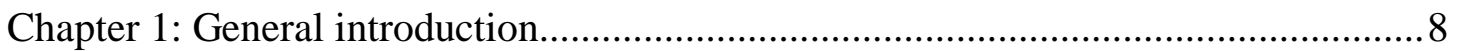

Patterns and causes of genetic connectivity ............................................... 8

New Zealand physical geography ........................................................... 14

Phylogeography of New Zealand's marine fauna.......................................... 17

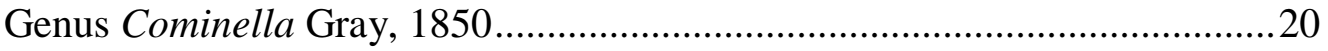

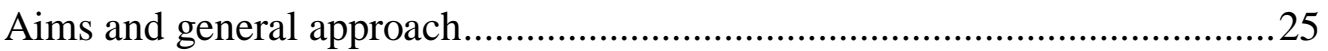

Chapter 2: Phylogeography of Cominella (Cominella) maculosa (Martyn, 1784) and C. (Cominula) virgata H. Adams \& A. Adams, 1853 (Gastropoda: Neogastropoda:

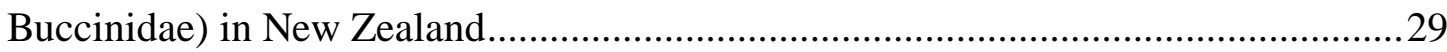

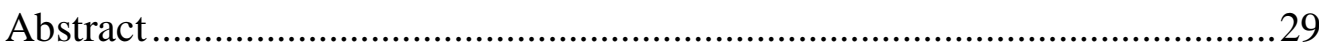

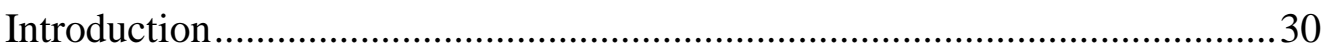

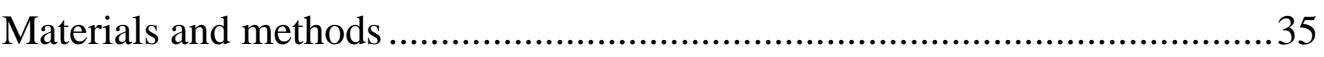

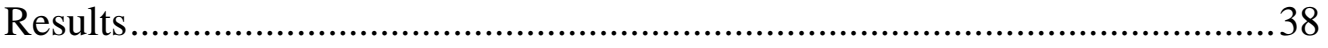

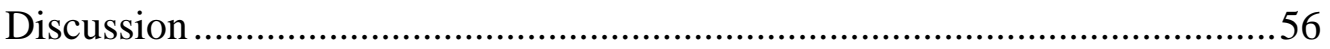

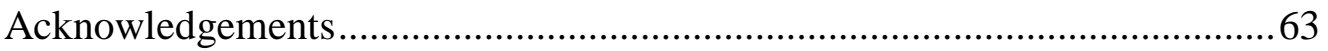

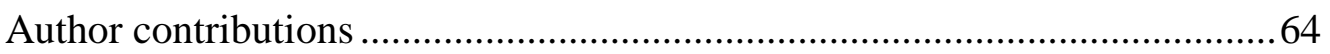

Chapter 3: General conclusion and closing remarks...............................................65

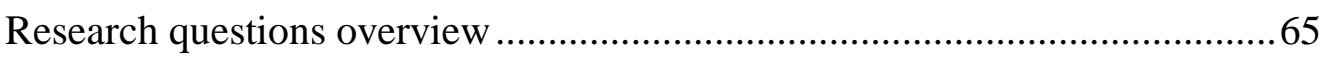

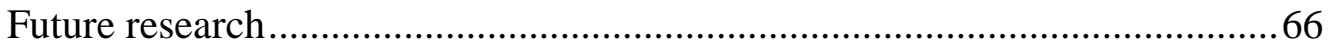

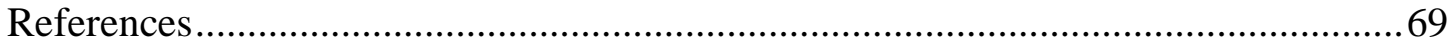

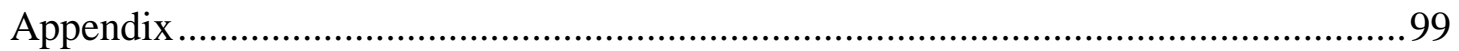




\section{List of figures}

Chapter 1:

Figure 1.1. Examples of phylogeographic structure assuming differing levels of gene-flow. Different colours represent different haplotypes. A) Panmixia. B) Isolation by distance. C) Distinct populations. Redrawn from Wilcox (2015)

Figure 1.2. Bathymetric map of New Zealand. Red dashed line shows plate boundary, grey dashed line shows outline of Zealandia, inset shows New Zealand in relation to Australia. Image: Alexander Karnstedt 2008

Figure 1.3. New Zealand's changing coastlines and predominant surface currents (arrows). A) Pliocene (6-2 Ma BP). B) Last Glacial Maximum (c.17 ka BP). C) Present day. Adapted from Stevens and Hogg (2004).

Figure 1.4. New Zealand ocean circulation. EAC: East Australian Current. WAUC: West Auckland Current. EAUC: East Auckland Current. STW: sub-tropical water. SAW: sub-antarctic water. STF: Sub-tropical Front. Red and blue arrows depict the movement of sub-tropical and sub-antarctic water respectively. Adapted from Carter et al. (1998)

Figure 1.5. Cominella species with egg masses. A) C. maculosa, Owenga, Chatham Islands. This rock had just been upturned. Note communal egg-laying and eggs attached to living snails. Image: Pat Lakeman 2013. B) C. adspersa, Marfells Beach, Marlborough. C) C. virgata, Oriental Bay, Wellington

Figure 1.6. Maps showing sample sizes (numbers) and sites. Red dots and bold and italicised location names correspond to sites originating from this study; others comprise the dataset of Fleming et al. (in review).

A) C. maculosa. B) C. virgata.

Chapter 2:

Figure 2.1. A) Median joining CO1 haplotype network for C. maculosa. Hatch-marks represent one mutational step. B) Sample sizes (numbers) and sites (coloured circles). Colours correspond to the haplotype network regions (see key). Bold and italicized location names correspond to sites originating from this study. Others comprise the dataset of Fleming et al. (in review). C) Distribution records of $C$. maculosa held at NMNZ... 
Figure 2.2. A) Median joining $\mathrm{CO} 1$ haplotype network for $C$. virgata. Hatchmarks represent one mutational step. B) Sample sizes (numbers) and sites (coloured circles). Colours correspond to the haplotype network regions (see key). Bold and italicized location names correspond to sites originating from this study. Others comprise the dataset of Fleming et al. (in review). C) Distribution records of $C$. virgata held at NMNZ. Note the disjunct population centres

Figure 2.3. A) Median joining $16 \mathrm{~S}$ haplotype network for C.virgata. Hatchmarks represent one mutational step. B) Sample sizes (numbers) and sites (coloured circles). Colours correspond to the haplotype network regions (see key). Bold and italicized location names correspond to sites originating from this study. Others originated from Donald et al. (2015) via GenBank

Figure 2.4. Rarefaction curves for $\mathrm{CO} 1$ haplotypes of A) C. maculosa. B) $C$. virgata....

Figure 2.5. Bayesian phylogenetic tree of concatenated CO1 (528 bp), 16S (457 bp) and 18S (711 bp) gene sequences totalling 1,696 bp. Node labels correspond to Bayesian posterior probabilities (left) and maximum likelihood (ML) consensus bootstrap support percentage (right), the latter from a ML tree with very similar topologies (see appendix). Bold and italicized sequence labels correspond to sequences originating from this study. Others originated from Donald et al. (2015) via GenBank (Table 2.2). '*' denotes specimens of $C$. virgata of the 'brookesi' shell form.

Figure 2.6. Type specimens and variations of $C$. virgata to scale. A) Pink Beach, Leigh, M.090919. B) Waihau Bay, Raukumara Peninsula, M.321237. C) Bay of Islands, lectotype (here designated) of both Buccinum lineolatum Quoy \& Gaimard, 1833 and C. virgata $\mathrm{H}$. Adams \& A. Adams, 1853, MNHN-IM-2000-6968. D) Te Hapua, Parengarenga Harbour, M.278721. E) Whatuwhiwhi, Karikari Peninsula, holotype of C. virgata brookesi Powell, 1952, AM 71191. F) The Bluff, Ninety Mile Beach, M.278743. G) Reef Point, Ahipara, M.278752. 


\section{List of tables}

Chapter 2:

Table 2.1. Sample locality information, summary statistics and haplotype lists. $\mathrm{n}=$ sample size; $\mathrm{s}=$ number of segregating sites; $\mathrm{h}_{\mathrm{p}}=$ number of private haplotypes; $h_{n}=$ number of haplotypes; $h_{d}=$ haplotype diversity (standard deviation); $\pi=$ nucleotide diversity (standard deviation); $\mathrm{k}=$ average number of nucleotide substitutions. Rows in bold denote samples originating from this study. The rest comprise the dataset of Fleming et $a l$. (in review). Each haplotype is identified by a number. ' $6(20)$ ', for example, would refer to 20 sequences of haplotype ' 6 '. '*' denotes haplotypes private to that site; '\#' denotes haplotypes private to one site.

Table 2.2. Samples used in molecular analyses and GenBank accession numbers where available. Rows in bold denote samples originating from this study. Others originated from Donald et al. (2015) via GenBank

Table 2.3. Cominella maculosa AMOVA a priori groups and results. $\mathrm{df}=\mathrm{degrees}$ of freedom; 'var. comp.'=variance components; '\%var.'=percentage variation; 'hapl. freq.'=measured by haplotype frequency; 'gen. diff.'= measured by genetic difference

Table 2.4. Cominella virgata AMOVA a priori groups and results. $\mathrm{df}=\mathrm{degrees}$ of freedom; 'var. comp.'=variance components; '\%var.'=percentage variation; 'hapl. freq.'=measured by haplotype frequency; 'gen. diff.' = measured by genetic difference 


\section{Chapter 1: General introduction}

\section{Patterns and causes of genetic connectivity}

The suggestion by science-fiction writer Douglas Adams that 'reality is frequently inaccurate' is jest, used here to reflect the incredible diversity in the biological world. Many key definitions in biology are contentious or somewhat subjective, in part because there are so often cases of biological systems that do not fit into a generalisation. The various species definitions (Mayr 1957; Sokal and Crovello 1970; Donoghue 1985) provide a prime example. Herein, a species is defined as a group of individuals and populations capable of interbreeding, but reproductively incompatible and isolated from other such groups (adapted from Mayr 1992: 222).

Biogeography can be loosely defined as the study of patterns and mechanisms behind the historic and contemporary distributions of species (adapted from Craw 1989: 527), whereas phylogeography pertains to the examination of mechanisms behind the extent and geographic distribution of genetic diversity within a species (Avise et al. 1987; adapted from Avise 2000: 270; Teske et al. 2011).

The parameters of a species' distribution, as well as how individuals and genetic variation are dispersed within, are determined by numerous and complex processes. The extent of a distribution can be determined by targeted sampling, recorded observations from area surveys, and the examination of reference collections from a range of contributors. Discerning past distributions is more difficult due to temporal and spatial gaps both in historic collections and fossil records, as well as due to bias introduced by fossilization processes and sampling (Koch 1978; Crampton et al. 2003; Cooper et al. 2006). DNA-based methods can be used to infer some historic population characteristics, but these are limited to features such as effective population 
size, gene flow and regional affiliations (Hey and Nielsen 2004; Drummond et al. 2005; Li and Durbin 2011).

Organisms are seldom evenly distributed across a landscape or seascape and often form groups or aggregate in higher relative densities for the purposes of breeding, predator protection, feeding, and/or accessing favourable habitat (Holmes et al. 1994; Parrish and Edelstein-Keshet 1999; Castro et al. 2002). The formation of discrete or semi-discrete groups of individuals is often influenced by local geography and limitations to the dispersal potential of the species. A population can be defined from a genetic perspective as a cohesive group of interbreeding individuals that are most likely to mate with others of the same group. This localised pattern of interbreeding and mating isolation means the evolutionary processes of genetic drift, selection and mutation will operate semi-independently from other populations resulting in genetic differentiation among populations and the presence of geographic structuring to genetic variation across a species' distribution.

The rate of intermixing between two populations is dependent on the dispersal ability of the species as well as the presence and permeability of geographic barriers and the ability of migrants to find a mate or access suitable breeding sites. The level of gene-flow determines, in part, the similarity of allele frequencies between populations. Although the possible levels of gene-flow form a continuum, relative gene-flow can be quantified by its effects on genetic diversity. High gene-flow leads to 'panmixia', a single metapopulation with little or no allele-frequency differences between regions (Fig. 1.1A). Weak gene-flow over relatively short distances can lead to gradients of allele frequency changes along a geographic transect, known as isolation by distance (IBD). In this pattern of genetic structure, adjacent populations are more closely related to one another than to those further apart (Laikre et al. 2005; Fig. 1.1B). Little or no gene-flow leads to discrete populations that have significantly different allele frequencies and unique alleles (Fig. 1.1C). Prolonged lack of migration between populations will result in reproductive isolation, the accumulation of genetic differences and, ultimately, reproductive 
incompatibility resulting in speciation (Rice and Hostert 1993; Palumbi 1994; Cruickshank and Hahn 2014).

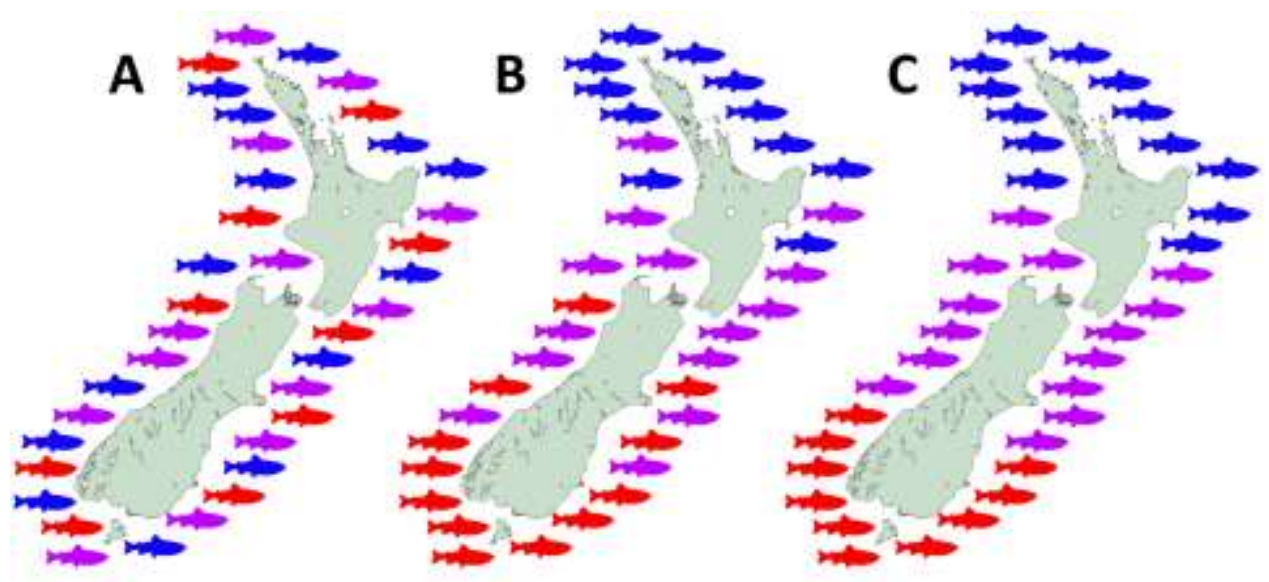

Figure 1.1. Examples of phylogeographic structure assuming differing levels of gene-flow. Different colours represent different haplotypes. A) Panmixia. B) Isolation by distance. C) Distinct populations. Redrawn from Wilcox (2015).

Demographic coupling of populations is different from genetic connectivity between populations, because it is dependent on the proportion of reproductively successful migrants relative to the population sizes (Lowe and Allendorf 2010; Ovenden 2013). In contrast, genetic connectivity is determined by an absolute number of migrants (Ovenden 2013). Very few migrants per generation are needed to constitute 'high' gene-flow and homogenise genetic variation among populations (Mills and Allendorf 1996; Lowe and Allendorf 2010; Ovenden 2013). The fixation index $(F)$ is often used to test for genetic differentiation and can be calculated using the equation: $F_{S T}=\frac{1}{4 N_{e} m+1}($ Wright 1969; Ovenden 2013), where ' $m$ ' is the proportion of migrants relative to the effective population size $\left(N_{e}\right)$. Higher $F_{S T}$ values denote greater genetic difference between populations (Ovenden 2013).

In marine systems, geographic features such as straits, peninsulas, ocean circulation patterns and rivers can hinder or prevent the movement of individuals between populations, and by extension, limit the level of gene- 
flow (Slatkin 1987; Manel et al. 2003). How geographic features influence gene-flow depends on species characteristics such as longevity, pelagic larval duration (PLD), swimming ability and orientation, habitat specificity, and tolerances for a range of abiotic factors (Slatkin 1987). Such abiotic factors include habitat availability, temperature, salinity, sedimentation and climate (Slatkin 1987; Bradbury et al. 2008).

With geographies changing over time and species continually evolving, observed phylogeographic patterns can be due, in part, to historic barriers to dispersal or species characteristics (Slatkin 1987). It is difficult to infer causality or deconstruct the individual effects of synergistic contributing factors when interpreting phylogeographic data. Identification of potentially congruent or convergent phylogeographic patterns in different species can aid the interpretation of phylogeographic data making it important to examine the growing body of data from regional bio- and phylogeographic studies based a diverse range of species and genetic markers. Dispersal ability and barrier permeability may differ between species or throughout ontogeny, especially for invertebrates, which often have larval morphologies that are quite distinct from the adult form (Ross et al. 2009; Gardner et al. 2010).

Dispersal as larvae and other pre-settlement processes significantly influence the levels of gene-flow of many benthic marine species (Bradbury et al. 2008; Ross et al. 2009) but aspects of the larval stage such as positioning in the water column, swimming behaviours, survivorship and distribution are seldom well understood (Ross et al. 2009). Early paradigms held that marine habitats are largely open to dispersal between populations because of the lengthy larval duration of many species and capacity of currents to transport larvae long distances (Mayr 1954; Palumbi 1994; Warner and Cowen 2002). However, the prevalence and importance of self-recruitment in populations is becoming increasingly apparent, even among species with considerable dispersal potential (Sponaugle et al. 2002; Swearer et al. 2002). While the presence or extended duration of a pelagic larval phase often relates to increased geneflow (Thorson 1950; Mileikovsky 1971) and/or dispersal ability, several factors including competitive exclusion (Waters 2011; Waters et al. 2013), 
larval retention in local eddies (Chiswell and Roemmich 1998; Chiswell and Booth 1999) and local selection pressures (Gardner et al. 2010) make PLD a poor predictor of dispersal ability and/or gene-flow (Bay et al. 2006; Haye et al. 2014).

Multiple layers of information about the distribution of species have allowed researchers to broadly characterise regional faunas. Elements of distribution patterns or phylogeographic structuring for different species are often similar because they have experienced the same environmental influences and changes (Teske et al. 2011). Similarities of distribution patterns have been used to suggest various schemes of biogeographic regions (reviewed by Shears et al. 2008). However, the division of an area into biogeographic regions has been a contentious approach as it relies on the classification of non-discrete characters, i.e., species' distributions. After examining well-established distribution boundaries of hundreds of mollusc species in relation to proposed biogeographic areas, several researchers (Dell 1962; Beu 2012; B.A. Marshall pers. comm. 2016) concluded that many of the proposed biogeographic boundaries were poorly supported or could not be precisely localised and are, thus, better viewed as regions with gradients of faunal composition changes.

The extent and significance of overlap between proposed biogeographic regions and phylogeographic structure is widely discussed (Avise 1992; Burton 1998; Waltari et al. 2007) and presumably relates to differences between species and haplotype occupancy times. Haplotypes are usually shorter-lived than species, depending on the markers and species studied. This discrepancy allows different influences and dispersal barriers to emerge, resulting in differing patterns of species and haplotype distributions.

The amount of genetic variation that accumulates and the rates of change differ relative to population size, the degree of admixture between populations, and the DNA marker chosen. Accordingly, selecting a sample design and DNA markers with an appropriate degree of resolution is important for successfully addressing a proposed question (Sunnucks 2000: Hills et al. 2011). The various DNA marker types differ in their degree of resolution, 
which is a product of the number of loci sampled, mutation rate, mode of inheritance (single- or bi-parental), and the amount of recombination that occurs. A range of molecular methods are currently available, which differ in their requirements for development time, resources, and sample quality.

Allozyme electrophoresis, although often cheap and easy to develop, offers relatively low levels of resolution and statistical confidence (Mueller and Wolfenbarger 1999). DNA microsatellites remain a common method but can be time consuming to develop for each study taxon (Gardner et al. 2010). With ever decreasing cost and increasing efficiency, DNA sequence-based analyses are very popular with contemporary phylogeographic studies (Teske et al. 2011).

Unlike nuclear DNA, mitochondrial DNA (mtDNA) does not undergo recombination and is maternally inherited in most animal groups, making it more likely to preserve the genetic patterns of a population's demographic history. However, most common mtDNA markers have less power to detect recent admixture and mtDNA can be subject to very rare interspecies exchanges (Shaw 2002; Leaché and McGuire 2006). The best approach is to use sequences from both mitochondrial and nuclear DNA sources. New genome-wide DNA sequence techniques offer a high degree of resolution and a more comprehensive dataset for less effort. Single-nucleotide polymorphisms (SNPs) and massively parallel DNA sequencing are becoming increasingly popular, but for now, the cost and development time remains prohibitive for small projects.

The body of studies relating to the distribution of genes and species is rapidly growing. This enables researchers to gain a clearer understanding of the influence of geography, abiotic and biotic factors, and morphological or behavioural characteristics on the ability or probability of individuals to survive in or disperse across an area. This knowledge helps to inform planning of Marine Protected Areas (MPAs) (Palumbi 2003; Laurel and Bradbury 2006; Rocha et al. 2007; Bell 2008; Arrieta et al. 2010; Baco et al. 2016), management of ecosystem resources, endangered species or those 
commercially exploited (Carvalho and Hauser 1994; Jennings et al. 1999; Ward 2000; Manel et al. 2003; Palumbi 2003; Claudet and Pelletier 2004) and make predictions on the influence of changes to the environment in the future (Palumbi 2003; Baco et al. 2016).

\section{New Zealand physical geography}

New Zealand is an archipelago in the South Pacific roughly $2000 \mathrm{~km}$ southeast of Australia (Close et al. 1978; Fig. 1.2). The emergent landmass lies on the largely submerged continent Zealandia (Chapple et al. 2009; Mortimer et al. 2017; Fig. 1.2) with the two largest islands, constituting 'the mainland', spanning approximately $13^{\circ}$ of latitude (Sponer and Roy 2002; Will et al. 2015). New Zealand has the fifth largest exclusive economic zone (EEZ) in the world (Chiswell et al. 2015), encompassing more than $30^{\circ}$ of latitude and over 700 islands (Gordon et al. 2010). Bisecting New Zealand is a plate boundary between the Pacific and Indo-Australian plates (Weissel et al. 1977; Fig. 1.2) and tectonic forces have significantly shaped the geography (Weissel et al. 1977; Hoernle et al. 2006; Trewick et al. 2007; Landis et al. 2008; Giribet and Boyer 2010) and biology (Heads 1998; Trewick and Wallis 2001) of the region.

Parts of Zealandia have been subjected to repeated tectonic uplift and/or subsidence (Trewick et al. 2007; Landis et al. 2008; Chapple et al. 2009), notably resulting in a period of considerable marine transgression during the Oligocene (Campbell and Landis 2003; Waters and Craw 2006; Trewick et al. 2007; Landis et al. 2008; Bunce et al. 2009). More recently, drastic changes in eustatic sea-levels during Pliocene and Pleistocene glacial cycles have led to the episodic emergence and closure of numerous marine straits (Lewis et al. 1994; Beu 2004; Stevens and Hogg 2004; Carter 2005; Bunce et al. 2009; Chapple et al. 2009; Fig. 1.3). 


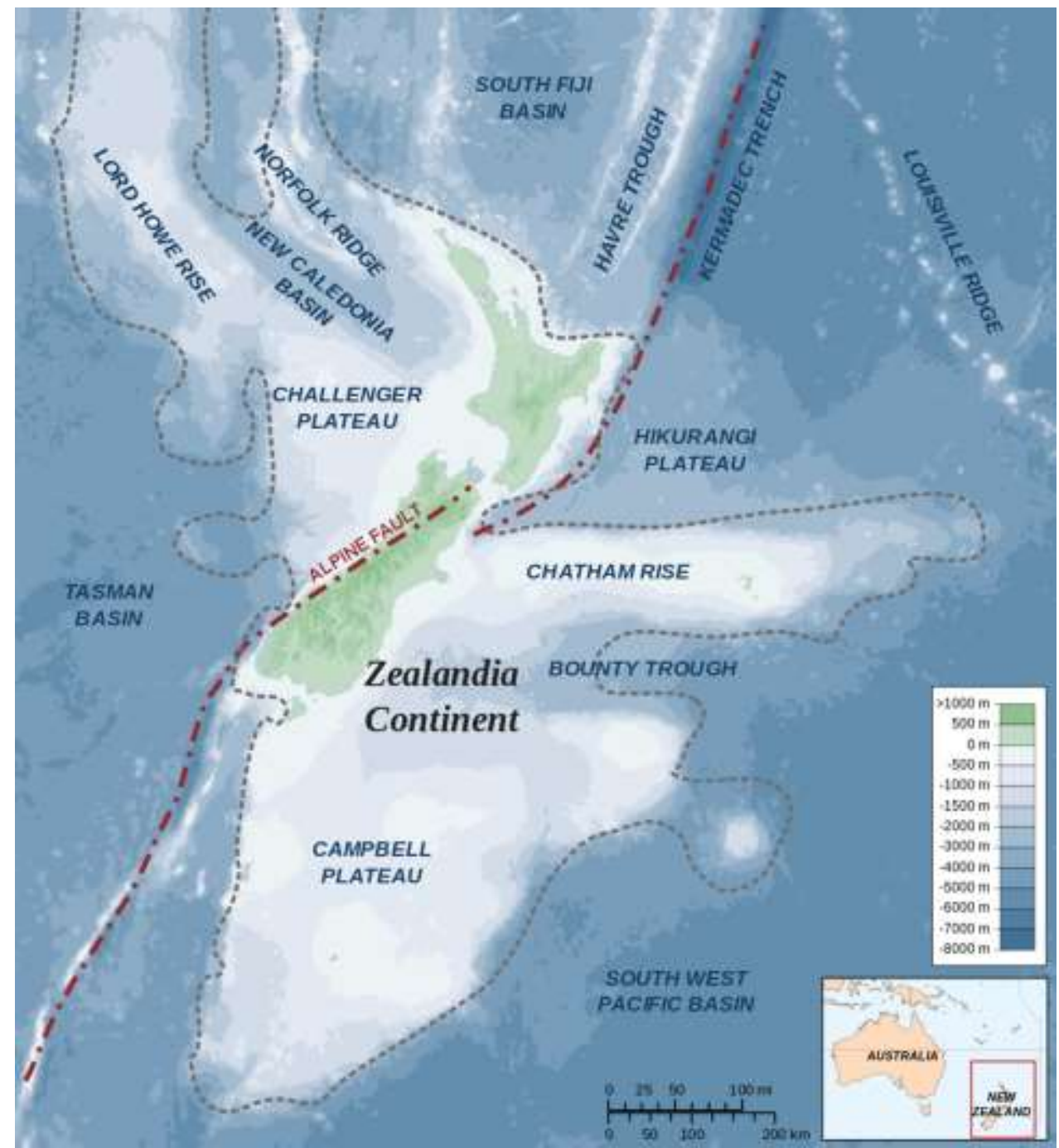

Figure 1.2. Bathymetric map of New Zealand. Red dashed line shows plate boundary, grey dashed line shows outline of Zealandia, inset shows New Zealand in relation to Australia. Image: Alexander Karnstedt 2008.

During the Pliocene and Early Pleistocene, must of the area currently forming the southern North Island was partially inundated, resulting in the formation of numerous islands and straits (Lewis et al. 1994; Stevens and Hogg 2004; Bunce et al. 2009; Fig. 1.3). Cook Strait first appeared c.450 ka BP (Lewis et al. 1994). Further north, the narrow and low-lying Auckland Isthmus has also been bisected repeatedly by straits in the Pliocene (Beu 2004; Stevens and Hogg 2004; Fig. 1.3) and possibly the Pleistocene (Beu 2004) but the location and timing of such events is poorly constrained (B.W. Hayward pers. comm. 2016; Chapter 3). 


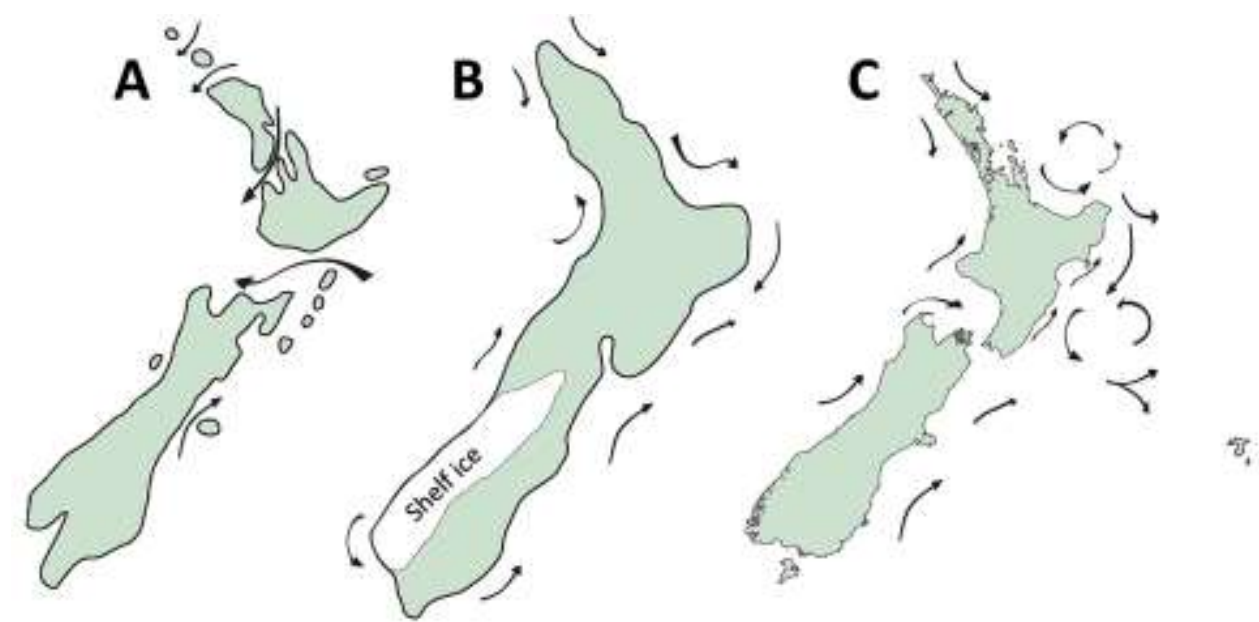

Figure 1.3. New Zealand's changing coastlines and predominant surface currents (arrows). A) Pliocene (6-2 Ma BP). B) Last Glacial Maximum (c.17 ka BP). C) Present day. Adapted from Stevens and Hogg (2004).

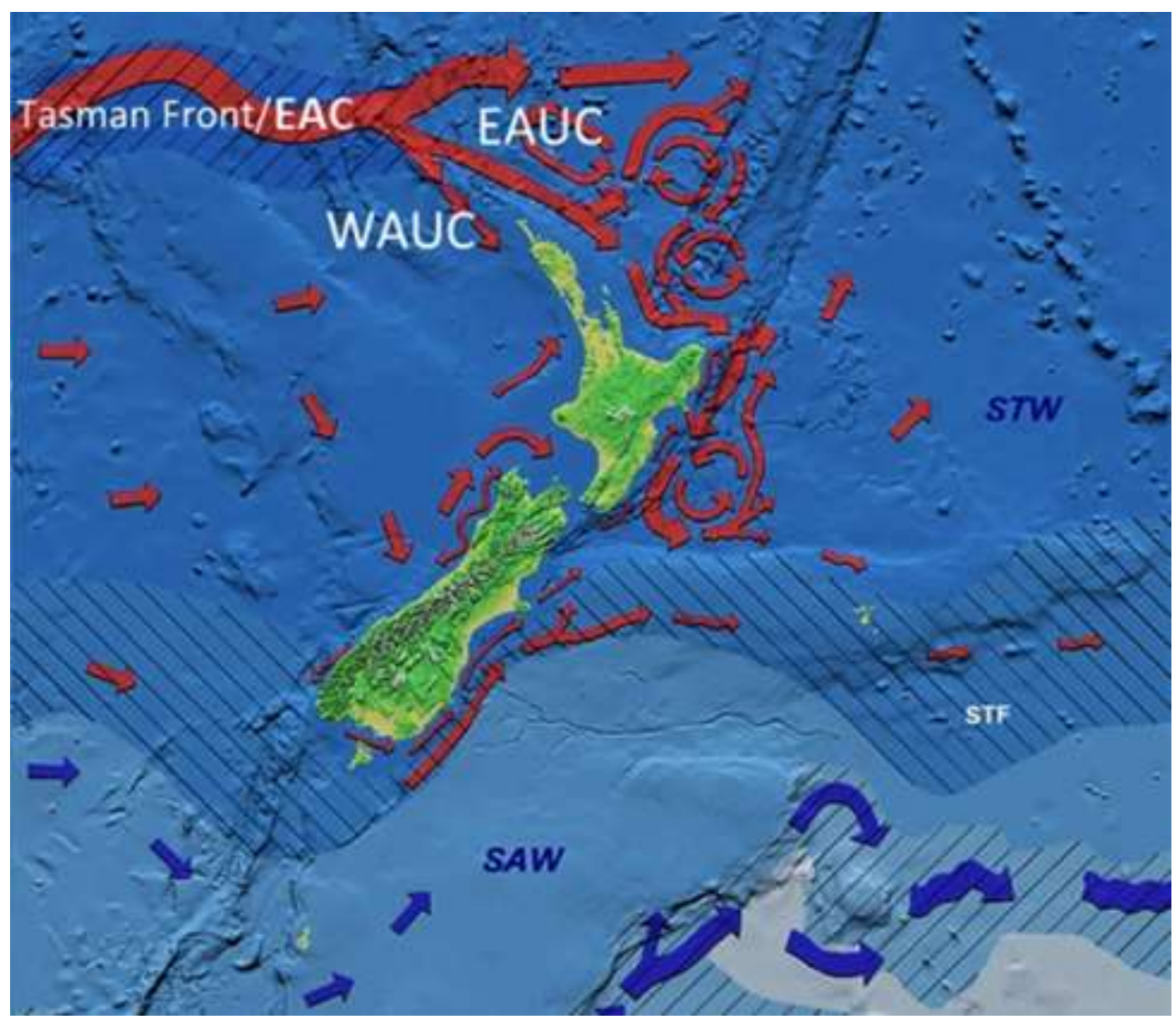

Figure 1.4. New Zealand ocean circulation. EAC: East Australian Current. WAUC: West Auckland Current. EAUC: East Auckland Current. STW: sub-tropical water. SAW: sub-antarctic water. STF: Subtropical Front. Red and blue arrows depict the movement of subtropical and sub-antarctic water respectively. Adapted from Carter et al. (1998). 
New Zealand lies on a boundary between sub-tropical and sub-antarctic water, demarcated by the Sub-tropical Front (Fig. 1.4), which runs along the southern coast of the South Island, along the Chatham Rise and past the Chatham Islands (Heath 1981; Butler et al. 1992) where it results in a productive (Bradford 1983) marine fauna.

The East Australian Current transports sub-tropical water south along the Queensland coast before heading eastwards across the Tasman Sea, where it becomes known as the Tasman Front. Near north-western New Zealand, the Tasman Front bifurcates to form the West Auckland and East Auckland currents (Godfrey et al. 1980; Chiswell et al. 1997; Ridgway and Dunn 2003; Fig. 1.4). Between these major current systems run a myriad of smaller current networks, deep-water currents, eddies and gyres (Bowman et al. 1983). Those nearest the coasts and fine scale movements are currently poorly understood.

A dynamic geological history, considerable geographic and temporal isolation from other land-masses and complex oceanography (Bradford-Grieve et al. 1991; Ross et al. 2009) have resulted in striking endemism in the contemporary flora and fauna of New Zealand. While few taxonomic groups present in New Zealand prove to have a vicariant Gondawanan origin (Waters and Craw 2006; Waters 2008; Giribet and Boyer 2010), trans-Tasman or other cross-border dispersal events are likely to be very rare in many terrestrial or coastal marine groups. Accordingly, there is a high rate of endemism in New Zealand species, which primarily result from local radiations. The unique biota and diversity of climatic and habitat extremes in a relatively small area makes New Zealand an excellent location to study biogeography and phylogeography (Giribet and Boyer 2010).

\section{Phylogeography of New Zealand's marine fauna}

The phylogeography of New Zealand's marine fauna has been reviewed by Ross et al. (2009), Gardner et al. (2010) and Hannan et al. (2016), citing 
between them over 60 studies, and several have been published subsequent to 2010 (Hannan et al. 2016 reviewed soft-sediment taxa only). A relatively large number of studies are available from New Zealand compared with other regions around the world (Hardy et al. 2011; Teske et al. 2011), however, when divided up into markers used, geographic coverage, phyla, life history strategies or habitat type, few studies are directly comparable.

Studies using different markers often present contrasting patterns of connectivity, perhaps reflecting marker sensitivity, geographic coverage or sample sizes. Examples include the paua Haliotis iris Gmelin, 1791 (Frusin 1982; Smith and McVeagh 2006; Will and Gemmell 2008; Will et al. 2011; Will et al. 2015), mussel Perna canaliculus (Gmelin, 1791) (Smith 1988; Gardner et al. 1996; Apte and Gardner 2001, 2002; Apte et al. 2003; Star et al. 2003; Wei et al. 2013a, b) and crayfish Jasus edwardsii (Hutton, 1875) (Smith et al. 1980; Ovenden et al. 1992; Morgan et al. 2013; Thomas and Bell 2013). These examples also demonstrate a bias in the literature favouring commercially exploited species, in part driven by funding availability. Additionally, there is a bias against smaller, obscure or less charismatic taxa and groups. Few phylogeographic studies feature, for example, species smaller than $10 \mathrm{~mm}$. Phylogeographic principles and biases appear congruent globally.

Studies often do not cite historical records from museum collections and midden sites or distribution information beyond their sampling coverage. Such information would help to establish natural distributions or potential for human influence on a species' distribution or genetic structure. Potential human mediated translocation events or range shifts are also seldom discussed in detail and smaller signatures of translocation may be dismissed as artefacts, natural or indeterminate in origin.

Maritime biosecurity efforts tend to focus on vessels crossing international borders rather than domestic movements. Exotic species are being detected at a greater rate than ever before, both in New Zealand and globally (Bax et al. 2003), probably reflecting a combination of increasing shipping volumes, biosecurity search effort and changing climatic conditions. The extent of 
human mediated translocation events through different vectors is most studied in invasive species (Bax et al. 2003; Ruiz and Carlton 2003) while the effects of domestic vessel movements on native species remain to be established and may be more difficult to observe.

The New Zealand marine region has a number of regions frequently associated with phylogeographic breaks. Several north/south breaks have been reported in the Cook Strait region for a variety of taxa (Apte and Gardner 2002; Apte et al. 2003; Star et al. 2003; Waters and Roy 2004; Ayers and Waters 2005; Goldstien 2005; Goldstien et al. 2006; Veale and Lavery 2011; Wei et al. 2013a, b), although the precise location, nature and causes of these breaks are unclear (Ross et al. 2009) and may differ between species. East/west breaks are also commonly but less frequently reported (Schnabel et al. 2000; Stevens and Hogg 2004; Knox et al. 2011; Veale and Lavery 2011) but are not readily associated with a single region or attributable to any one cause. Most studies have too few sample sites to narrow down break localities, and sampling sites differ between studies, hampering direct comparison. Breaks are often associated with or superimposed against proposed biogeographic provinces (Shears et al. 2008) but the degree of correlation is often low (Ross et al. 2012; Veale and Lavery 2012). Interpretations frequently focus on the single line of explanation deemed to be the most probable for each detected pattern. Speculation regarding the causes of phylogeographic patterns can direct further research but should be approached with caution. Often results will simply provide more questions than answers.

Related species with similar life-history strategies frequently have differing patterns of phylogeographic structure (Goldstien 2005; Goldstien et al. 2006; Stevens and Hogg 2004; Knox et al. 2011). Multiple studies featuring different species and markers are needed to determine if repeating patterns are due to common causes or to infer or deconstruct causality with greater confidence (Ross et al. 2009). 
Genus Cominella Gray, 1850

The large and widespread neogastropod superfamily Buccinoidea comprises a diverse group of families, genera and species (Bouchet and Rocroi 2005;

Kosyan and Kantor 2007). Despite several anatomical and molecular reviews, taxonomic relationships within Buccinoidea remain contentious (Ponder 1973; Harasewych 1998; Harasewych and Kantor 1999; Kantor 2003; Kosyan and Kantor 2004, 2007; Hayashi 2005), due, in part, to often extremely variable shell morphologies (Walton and Marshall in prep.).

The familial placement of Cominella Gray, 1850 is unclear. The genus has previously been referred to its own family, Cominellidae Gray, 1857 (e.g. Powell 1929, 1937, 1946; Dell 1956; Marwick 1965; Morton and Miller 1968), however Cominella is here maintained in Buccinidae Rafinesque, 1815 in the interest of continuity pending more conclusive molecular and anatomical analyses of the superfamily. The type species is $C$. maculosa (Martyn, 1784) (=Buccinum testudineum Bruguière, 1789: ICZN opinion 479, 1957).

Within Cominella, five extant subgenera are recognised (Donald et al. 2015) comprising roughly 25 extant species, several of which are awaiting description (Walton and Marshall in prep.). All Cominella species are endemic either to Australia, Norfolk Island or New Zealand, and all extant subgenera are endemic to New Zealand except Josepha Tenison-Woods, 1879, which only contains the species from Australia and Norfolk Island (Donald et al. 2015). The presently available DNA sequences support the reciprocal monophyly of each subgenus (Donald et al. 2015; Chapter 2) although many of the rare or deep-water forms and species have yet to be collected alive in the molecular age.

Most Cominella species have highly variable shell morphologies both within and between populations, confounding specific determination or subgeneric placement in the absence of large samples and/or molecular data (Walton and 
Marshall in prep.). High diversity and a tendency for character convergence make the relationships of many fossil taxa difficult to discern and nonmolecular subgeneric diagnoses (e.g. Marshall et al. 2016) near-impossible. The interpretation of fossils in relation to the living fauna is further complicated when it is unclear if a fossil is a direct ancestor or extinct sister lineage (Magallón 2004; Rydin et al. 2004). Roughly half of extant Cominella species inhabit rocky coasts, a habitat with low fossilisation potential (Schopf 1978; Hayes et al. 1993), and the fossil record is likely biased towards softsediment dwelling species (Schopf 1978).

A fossil at the Museum of New Zealand Te Papa Tongarewa (NMNZ) from Sparrow Bluff (Kaimatira) along the Whanganui River and dating from the Late Pleistocene c.1 Ma BP (M.017786) is clearly of a species closely related to $C$. virgata but may not be a direct ancestor (pers. obs.). Marwick (1965) described and figured a Waitotaran fossil as C. virgata $\mathrm{H}$. Adams \& A. Adams, 1853 although the figured specimen is does not appear to be conspecific. It differs from C. virgata in having much stronger and more numerous spiral threads, narrower and more persistent axial costae and less evenly rounded teleoconch whorls. This was the source of the record in Beu and Maxwell (1990) and was subsequently used as a calibration node for the molecular clock of Donald et al. (2015). The ancestral state reconstruction of Donald et al. (2015) found slight support (probability = c.55\%) for a New Zealand origin of the genus subsequent to the divergence of New Zealand and Australia c.82 Ma BP (Kamp 1986). This suggestion was unexpected as Cominella species are thought to have a generally poor dispersal ability (Donald et al. 2015) and a New Zealand post-vicariance origin would have required a historic long-distance dispersal event counter to most regional oceanic circulation patterns (Donald et al. 2015; Fig. 1.4).

Australia has fewer Cominella species and several require revision. $C$. lineolata (Lamarck, 1816) is one such species, introduced as Buccinum lineolatum Lamarck, 1816, a name which has priority over the taxon of the same name of Quoy and Gaimard (1833), for which C. virgata H. Adams \& A. Adams, 1853 is a replacement name (Chapter 2). One of Lamarck's daughters 
annotated his collection in their personal copy of Lamarck (1822), now at the Muséum d'Histoire Naturelle de la Ville de Genève, Geneva, Switzerland (MHNG) (Beu and Cernorhorsky 1986). The annotations note two specimens of C. lineolata, each measuring 15 lines (E. Tardy pers. comm. 2017), equating to specimens approximately $33.84 \mathrm{~mm}$ in length converting from the French line. Two specimens (MHNG-MOLL-96341) are known at MHNG from the Delessert collection, which includes the Lamarck collection, but their provenance, and so type status, is uncertain (E. Tardy pers. comm. 2017). As these exactly match the annotations, they are very likely to be syntypes.

C. glandiformis (Reeve, 1847) from New Zealand occurs around the North, South, Stewart and Chatham Islands, exclusively in sheltered muddy intertidal habitats (Morton and Miller 1968), and forms a clade sister to that of all sampled congeners in some phylogenies (Donald et al. 2015). It has an extremely patchy distribution due to high habitat specificity, relatively little genetic divergence between widely separate populations (Donald et al. 2015) and the smallest protoconch $(0.80-0.85 \mathrm{~mm}$ versus $\geq 1.05 \mathrm{~mm})$ of any extant Cominella species. Accordingly, it seems plausible that $C$. glandiformis has or has recently had a pelagic larval stage. Gastropods with lecithotrophic larval development generally have relatively small protoconchs (Kano 2006). However, Morley (2013) did not mention swimming or free-floating hatchlings in laboratory observations of $C$. glandiformis egg masses and hatchlings, although observations were not made daily and hatchling emergence was not observed.

The transition between some larval development types may not be a slow or infrequent process as previously considered (McEdward and Janies 1997; McHugh and Rouse 1998; McEdward and Miner 2001; Collin 2004), and a change from lecithotrophy to entirely benthic direct development may simply reflect a change in the buoyancy of juveniles with no swimming ability sensu stricto. Newly emerged Cominella maculosa (Martyn, 1784) hatchlings have been observed to float on still water in laboratory conditions but would sink when disturbed (Dohner 2016). 


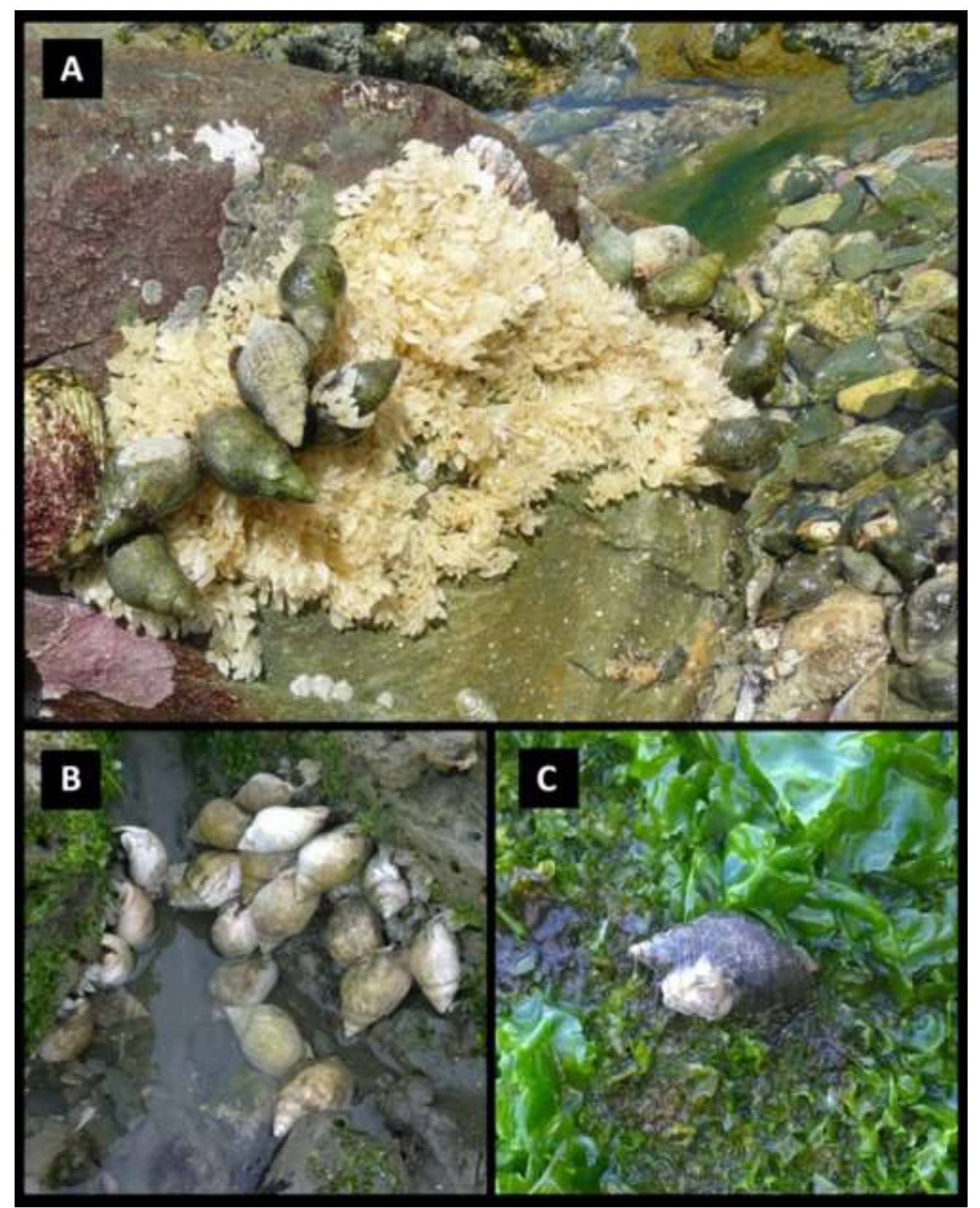

Figure 1.5. Cominella species with egg masses. A) C. maculosa, Owenga, Chatham Islands. This rock had just been upturned. Note communal egg-laying and eggs attached to living snails. Image: Pat Lakeman 2013. B) C. adspersa, Marfells Beach, Marlborough. C) C. virgata, Oriental Bay, Wellington.

Most Cominella species have relatively large and heavy paucispiral protoconchs, usually indicative of direct development (Walton and Marshall in prep.). It is likely that all extant species presently deposit leathery egg capsules onto hard substrates and have direct benthic development (Donald et al. 2015). 
The number of individuals in each egg capsule differs between species. In $C$. virgata, only one hatchling is thought to emerge from each egg capsule whereas about eight emerge from those of $C$. maculosa (Carrasco et al. 2012) after several months of development (van der Sman 2007). Neither $C$. maculosa nor $C$. virgata is thought to produce nurse eggs (Carrasco et al. 2012). C. glandiformis differs in having six to seven embryos in each egg capsule with some possibly serving as nurse eggs (Pilkington 1974). The frequency of laying and the number and distribution of egg capsules deposited by each female is unclear as they host communal broods (Carrasco and Phillips 2012; Fig. 1.5). In lab studies, individual female $C$. maculosa have been documented depositing up to 82 egg capsules (average $=28$ ) per year (van der Sman 2007; van der Sman et al. 2009).

Eggs of C. glandiformis have been observed on wood (Morley 2013), shell (Pilkington 1974) and seagrass, whereas those of $C$. adspersa (Bruguière, 1789), C. maculosa and C. virgata (Fig. 1.5) are normally cemented to the underside of rocks (Carrasco and Phillips 2012; Carrasco et al. 2012) but are sometimes attached to other snails (Fig. 1.5), crabs (Graham 1941) and potential rafting materials like algae, pumice and driftwood. Detached eggs of C. adspersa have been observed floating in calm water (Dohner 2016) and those of $C$. glandiformis attached to floating driftwood (Morley 2013). Even though they seldom associate with such materials, Cominella species frequently occur in high abundance and in close proximity to potential rafting material so occasional rafting events are likely (Donald et al. 2015). Rafting events may partially explain some of the patterns of phylogeographic structure in C. maculosa and C. virgata (Dohner 2016; Fleming et al. in review) as well as the occurrence of some species on outlying islands such as the Chatham Islands. 


\section{Aims and general approach}

Phylogeographic and phylogenetic studies often report differing patterns of connectivity and diversity between even closely related species (Stevens and Hogg 2004; Goldstien 2005; Goldstien et al. 2006; Knox et al. 2011). Multiple approaches that include a range of molecular markers and taxa are required to identify common patterns of population structure (Ross et al. 2009; Teske et al. 2011) and to improve the general understanding about the processes that influence of gene-flow and barriers to dispersal for coastal New Zealand organisms (Ross et al. 2009; Gardner et al. 2010).

C. maculosa and C. virgata frequently occur in high abundance on New Zealand coasts and are ecologically significant components of many inshore marine environments (Morton and Miller 1968). They are sympatrically occurring and easy to collect, making them well suited for phylogeographic study (Fleming et al. in review). Neither species is currently of commercial interest or of conservation concern, although observed patterns of genetic connectivity might be helpful for inferring patterns for other species, especially those that are rare or range-restricted and cannot practically be sampled in similar quantity, or those commercially harvested such as Penion sulcatus (Lamarck, 1816) and Austrofusus glans (Röding, 1798).

Fleming et al. (in review) presented a phylogeographic study using DNA sequences of the mitochondrial gene cytochrome c oxidase subunit 1 (CO1) from C. maculosa and C. virgata from the North Island south of Cape Rodney, and Nelson in the South Island (Fig. 1.6). Both species occur north of Cape Rodney, but populations of $C$. virgata in the northern North Island are especially morphologically diverse (pers. obs.). This diversity led Powell (1952) to distinguish some northern populations as the subspecies $C$. virgata brookesi Powell, 1952 (type locality: Karikari Peninsula). Even more divergent forms from the west coast of Northland were unknown to or not listed by Powell (1952), and shells of the various forms, including C. virgata virgata and C. virgata brookesi, appear to intergrade. However, it has been 
unclear if northern populations of $C$. virgata warrant subspecific distinction, and if so, where the boundaries between subspecies lie.

A concatenated three-gene phylogeny presented by Donald et al. (2015) proposed two major clades within $C$. virgata that the authors interpreted as corresponding to $C$. virgata virgata and $C$. virgata brookesi. That interpreted as $C$. virgata brookesi comprised samples from $<30 \mathrm{~km}$ away from its type locality and shell vouchers at NMNZ, corresponding to some of these sequences, closely resemble the holotype of $C$. virgata brookesi, held at the Auckland War Memorial Museum. However, this clade included a sequence from the Bay of Islands, which is the type locality of $C$. virgata virgata (designated by Powell 1952), and another from Taupiri Bay. Both of these voucher specimens are of the typical $C$. virgata virgata shell-form.

Several studies have identified a phylogeographic break in the northern South Island for a range of taxa (Waters and Roy 2004; Ayers and Waters 2005; Goldstien et al. 2006; Ross et al. 2009). Fleming et al. (in review) reported the presence in Nelson of C. maculosa and C. virgata haplotypes that were also found in the Hauraki Gulf but that were not known from the lower North Island. This result could suggest a possible genetic break occurring across the Cook Strait and/or translocation events.

This present thesis research expands the geographic coverage of the Fleming et al. (in review) CO1 dataset (Fig. 1.6) utilising an extension of their methodologies and DNA markers (Chapter 2). Seven and three additional South Island populations were sampled for C. maculosa and C. virgata respectively (Fig. 1.6), encompassing most of their ranges around the South Island (Chapter 2). The inclusion of these additional South Island populations into a combined dataset is used to establish if South Island populations are naturally occurring, to test for evidence of phylogenetic breaks or gene-flow across Cook Strait, and allow comparison of the expanded dataset with other studies with a focus on the Cook Strait region. Although few samples of $C$. maculosa were available from the Chatham Islands (Fig. 1.6), these were 
included to check for local cryptic diversity, mainland regional affiliation and to approximate the occupancy time of Chatham Islands populations.

Populations of $C$. virgata from Northland were included in the expanded CO1 dataset allowing these to be compared with the other North Island populations sampled by Fleming et al. (in review). The expanded $C$. virgata dataset is used to examine phylogeographic structure in populations from north of Cape Rodney, and establish if the geographically structured morphological diversity in this region was reflected in the diversity of the $\mathrm{CO} 1$ sequences. In addition, several phylogenies are presented using $\mathrm{CO} 1$ sequences as well as two additional DNA markers; the mitochondrial gene 16S rRNA and the nuclear gene 18S rRNA. Published sequences from Donald et al. (2015) were retrieved from GenBank (www.ncbi.nlm.nih.gov/genbank/). These phylogenies were used to test for reciprocal monophyly in samples representing the various forms and purported subspecies, with a view to review the support for the continued maintenance of distinct subspecies.

\section{Specific research questions}

- What are the patterns of phylogeographic structure of $C$. maculosa and C. virgata populations around the South Island and how do they compare with those of the North Island?

- How does the population genetic diversity in the Chatham Island populations of $C$. maculosa relate to mainland populations?

- How do patterns of phylogeographic structure present in the Northland population of $C$. virgata compare with those from other North Island localities?

- Do any forms of C. virgata warrant subspecific recognition based on a population-level sample of genetic data? 

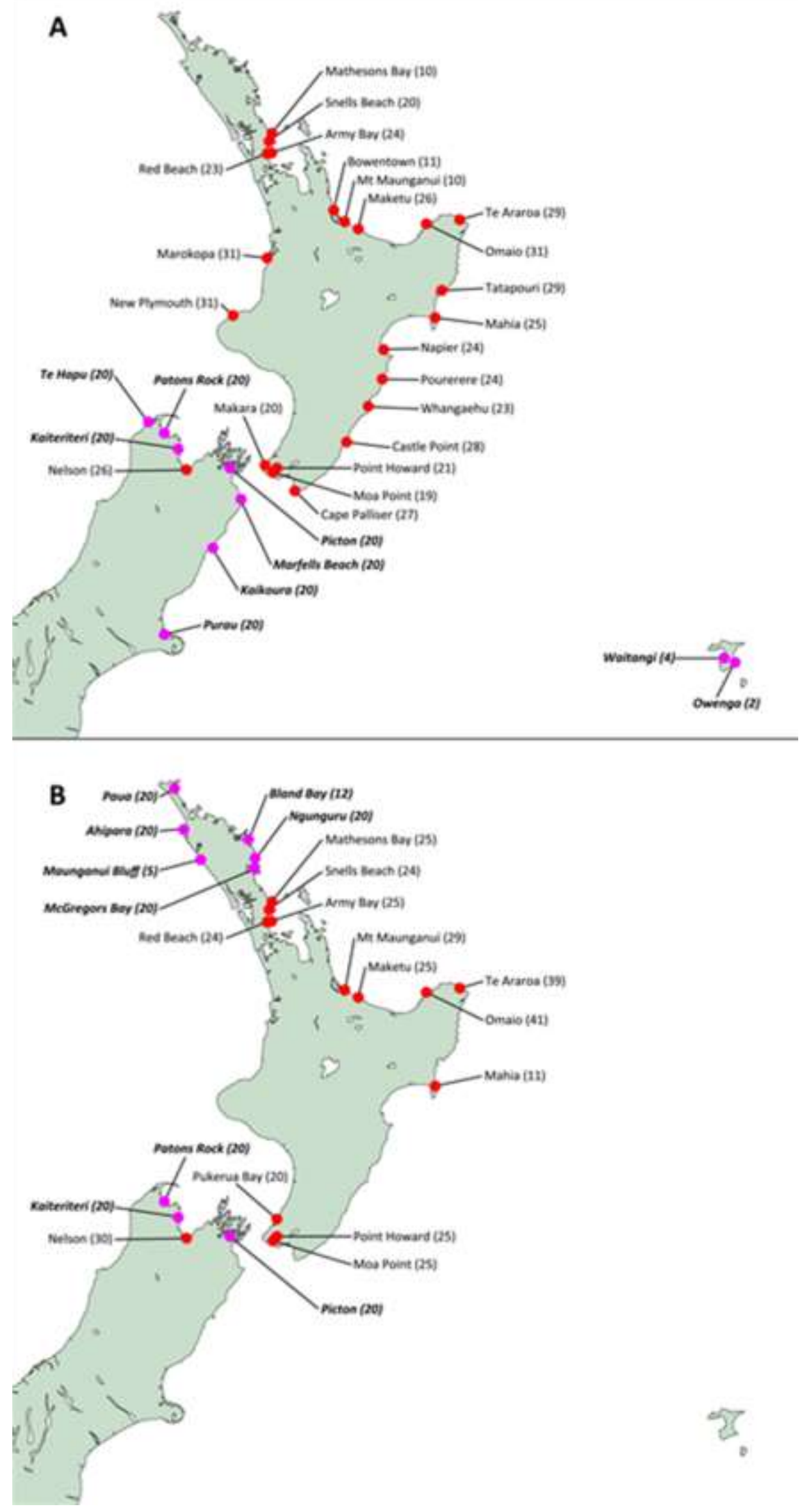

Figure 1.6. Maps showing sample sizes (numbers) and sites. Red dots and bold and italicised location names correspond to sites originating from this study; others comprise the dataset of Fleming et al. (in review). A) $C$. maculosa. B) C. virgata. 


\title{
Chapter 2: Phylogeography of Cominella (Cominella) maculosa
}

\author{
(Martyn, 1784) and C. (Cominula) virgata H. Adams \& A. Adams,
} 1853 (Gastropoda: Neogastropoda: Buccinidae) in New Zealand

\author{
Kerry Walton ${ }^{1,2}$, Bruce A. Marshall ${ }^{2}$, Nicole E. Phillips ${ }^{1}$, Peter A. Ritchie ${ }^{1 *}$ and \\ Alexander J.F. Verry ${ }^{1}$ \\ Author contributions detailed at end of chapter \\ *corresponding author: peter.ritchie@ vuw.ac.nz \\ ${ }^{1}$ School of Biological Sciences, Victoria University of Wellington \\ ${ }^{2}$ Museum of New Zealand Te Papa Tongarewa
}

Abstract

Cominella maculosa and $C$. virgata are common whelk species that inhabit rocky shores throughout much of the North Island, the northern South Island, and, for C. maculosa, the Chatham Islands. This study used DNA sequences from the mitochondrial gene cytochrome c oxidase subunit 1 (CO1) to expand an earlier unpublished dataset and examine the phylogeographic structure of populations of both species in the Cook Strait region, of C. maculosa in the Chatham Islands, and C. virgata in the northern North Island. Both species are found to have a considerable degree of phylogeographic structure. South Island populations of $C$. virgata may have originated from human-mediated translocations. Phylogenetic analyses were also conducted using the mitochondrial genes CO1 and 16SrRNA, and the nuclear gene 18S rRNA. The purported northern subspecies C. virgata brookesi does not form a monophyletic lineage and is synonymised with $C$. virgata. A lectotype is designated for Buccinum lineolatum Quoy \& Gaimard, 1833, of which Cominella virgata is a replacement name.

Keywords: Mollusca; Buccinoidea; genetics; systematics; taxonomy; lectotype; Cook Strait; Chatham Islands 


\section{Introduction}

Cominella Gray, 1850 is a genus comprising about 25 extant species, each endemic either to Australia, Norfolk Island or New Zealand (Donald et al. 2015). Cominella (Cominella) maculosa (Martyn, 1784) and C. (Cominula) virgata $\mathrm{H}$. Adams \& A. Adams, 1853 are common, sympatric, often syntopic, carnivorous (Ansell 2000; Stewart and Creese 2004; Morley et al. 2006) whelks. They are usually found in association with hard substrates (Morton and Miller 1968) and range from the intertidal zone to 16 and $11 \mathrm{~m}$ respectively. C. maculosa occurs throughout the North Island, the northern South Island, and the Chatham Islands (Fig. 2.1A). C. virgata is absent at the Chatham Islands (Marston 1996, 1998) and has a disjunct distribution comprising two population centres, one in the northern and north-eastern North Island, and the other in the Cook Strait region (Fig. 2.2A). Both species have direct development (Carrasco and Phillips 2012; Carrasco et al. 2012) and their abundance, similar distributions, habitats and behaviours make them ideal subjects for phylogeographic analyses in conjunction (Fleming et al. in review).

Species with direct development generally have poor dispersal ability, which makes them more likely to have genetically structured populations than species with a pelagic larval phase (Thorson 1950; Mileikovsky 1971). The egg capsules of C. maculosa and C. virgata are frequently cemented to substrates other than rock, such as crabs (Graham 1941), algae and other snails (Dohner 2016; Chapter 1). Development takes several months (van der Sman 2007). Detached egg masses of $C$. adspersa (Bruguière, 1789) have been observed floating in calm water (Dohner 2016) and those of $C$. glandiformis (Reeve, 1847) attached to floating driftwood (Morley 2013). Although Cominella species do not normally associate with substrates with high rafting potential (Donald et al. 2015), such as algae and driftwood, C. maculosa and C. virgata occur in high abundance near such materials and sporadic rafting events are likely, especially as egg capsules (Donald et al. 2015). Infrequent 
rafting events could explain some of the patterns of gene-flow in C. maculosa and C. virgata (Dohner 2016).

Juveniles and egg capsules of both species are sometimes found on the brown alga Carpophyllum maschalocarpum Turner (Greville, 1830), which occurs sympatrically throughout their distributions. Detached fronds from $C$. maschalocarpum form rafts capable of traversing Cook Strait and the Chatham Rise (Buchanan and Zuccarello 2012). The alga Durvillaea antarctica (Chamisso) Hariot, 1892 occurs throughout the South Island and sporadically around the southern North Island. It is significantly sturdier, larger and more buoyant, and accordingly, has even greater rafting potential (Collins et al. 2010; Nikula et al. 2010; Fraser et al. 2011; Nikula et al. 2011a, b) than $C$. maschalocarpum. D. antarctica has been implicated as a vector for gene-flow of several marine invertebrate species in southern New Zealand (Fraser et al. 2011; Nikula et al. 2011a, b).

Human activity can also result in the translocation of species through several vectors. Whilst shells of both C. maculosa and C. virgata have been found in low abundance in midden sites (Willan 1974; Hayward et al. 1978; Hayward 1982; Foster 1986), it is unlikely that either species formed a significant food source for Māori or was deliberately translocated. Although Cominella species dislodge easily, they could become established and be transported on heavily fouled hulls. Perhaps a more common vector for Cominella species relates to dry-ballast. Rocks were widely used as ballast in New Zealand as recently as the early 1900's (Moore and Kenny 1986; Hewitt et al. 2009) and many taxa, including commercially important and pest species, have been introduced or spread as bio-foul attached to or among ballast rocks (Carlton 1999; Bax et al. 2003; Carlton 2011). These types of human-mediated translocations are presumably most common in port areas.

Another means of unintentional human mediated dispersal may be via transport of craypots, which Cominella species regularly enter, attracted by the bait (Ansell 2000; Stewart and Creese 2004). C. maculosa and C. virgata can survive out of water for several days if they remain cool and moist. With many 
vessels running lines of craypots tens of kilometres apart, it is conceivable adult snails are regularly transported considerable distances, increasing the effective dispersal ability and rate for the species, although how significant this effect may be remains unclear.

\section{Geographic context}

Cook Strait bisects central New Zealand and features intricate submarine canyons and ocean circulation patterns (Bowman et al. 1983; Proctor and Carter 1989; Lewis et al. 1994). Complex and temporally variable geography and currents in the Cook Strait region have led to many differing patterns of phylogeographic structure in a range of marine invertebrates with various life history strategies (Stevens and Hogg 2004; Waters and Roy 2004; Ayers and Waters 2005; Goldstien et al. 2006; Knox et al. 2011; Veale and Lavery 2011; Veale and Lavery 2012). Many species exhibit a phylogeographic break in the Cook Strait region (Waters and Roy 2004; Ayers and Waters 2005; Goldstien et al. 2006), often to the south of Cape Campbell, although the location and causes of these breaks are often unclear (Ross et al. 2009).

During some Pleistocene glacial maxima, a land-bridge connecting Whanganui and Golden Bay closed Cook Strait (Fleming 1979; Proctor and Carter 1989; Lewis et al. 1994). For many marine species, the formation of continuous land between the North and South Islands would have severed gene-flow between the western and eastern coasts of central New Zealand. However, for terrestrial or coastal species with little or no long-distance overwater dispersal ability, this closure would have facilitated gene-flow between the North and South Islands (Fleming 1979; Liggins et al. 2008; O'Neill et al. 2008).

Between the onset of the Last (Otiran) Glacial Maximum (LGM) roughly 25 ka BP (Sandiford et al. 2002), and its more gradual end about 7 ka BP (Lambeck et al. 2002), eustatic sea-levels dropped as much as 120-130 m lower than at present (Fleming et al. 1998; Lambeck et al. 2002). A lack of fossil or molecular evidence for the exchange of several terrestrial vertebrates 
across a land-bridge during this time (Worthy and Holdaway 1994, 2002; Liggins et al. 2008; O’Neill et al. 2008) should not be interpreted as evidence for the lack of a land-bridge (Liggins et al. 2008; O'Neill et al. 2008). Such a land-bridge is likely to have been comprised mostly of low-lying coastal dunes and may have been short-lived or not conducive to the passage of larger terrestrial species (Greaves et al. 2008; O’Neill et al. 2008) such as moa. Several terrestrial species with presumed low dispersal ability do indeed show evidence of post-Pliocene genetic connectivity between the North and South Islands (O'Neill et al. 2008; Trewick et al. 2011), although their means of dispersal are unclear.

The shallowest possible connection between the North and South Islands, following Farewell Rise, has a maximum depth presently of 94 m (Lewis et al. 1994). However, little is known of the rates of uplift and subsidence in the vicinity of Farewell Rise, or rates of sedimentation from the Whanganui catchment or via west-wind drift from the north-western South Island (Lewis et al. 1994). Nevertheless there is no evidence that a land-bridge was not present as recently as 17-15 ka BP (Proctor and Carter 1989; Lewis et al. 1994).

The Chatham Islands lie roughly $700 \mathrm{~km}$ east of the New Zealand mainland and straddle the Subtropical Convergence, which directs relatively warm temperate water and cool sub-antarctic water eastwards along the Chatham Rise (Chiswell 1994). This confluence results in a productive local marine fauna (Bradford 1983), comprising species with both eastern North Island and eastern South Island affinities (Finlay 1928; Dell 1960; Craw 1988, 1989; Marshall and Walton 2015).

Despite the Chatham Islands having been isolated from the mainland for at least 70 Ma (Campbell et al. 1993; Emberson 1995; Trewick 2000) and by several hundred kilometres of ocean deeper than $200 \mathrm{~m}$, the region has few endemic coastal marine invertebrates (Young 1929; Beu 2012). Dell (1960) recorded 49 locally endemic species of marine molluscs from depths shallower than 20 m, but subsequent work (e.g. Ponder 1965a, b, 1972; Marshall 1993, 
1995, 1998a, b, 2003; Reisser et al. 2012; Marshall and Walton 2015; Walton and Marshall in prep.) suggests that no more than 10 named mollusc species or subspecies are truly unique to the Chatham Islands. The Chatham Islands were fully submerged upon splitting from the mainland, emerging as recently as the early Pliocene (Campbell 1998; Stevens and Hogg 2004), thus the terrestrial and coastal marine faunas comprise predominantly recent arrivals dispersed from the mainland (Trewick 2000).

\section{Study background and aims}

Fleming et al. (in review) reported DNA sequence data from the mitochondrial gene cytochrome c oxidase subunit 1 (CO1) from populations of C. maculosa and $C$. virgata from south of Cape Rodney in the North Island, and Nelson in the northern South Island (Figs. 2.1B, 2.2B). Fleming et al. (in review) found both species to have a considerable amount of phylogeographic structure while Nelson populations appeared distinct from those in Wellington. The present contribution includes populations of both species from the northern South Island, $C$. virgata from north of Cape Rodney, and C. maculosa from the Chatham Islands. Although only a few Chatham Islands samples of $C$. maculosa were available, these were included to check for cryptic diversity, mainland regional affiliation and to approximate the occupancy time of the Chatham Islands populations. The combined dataset now covers much of the distribution of these two species (Figs. 2.1C, 2.2C), enabling wider geographic comparison between populations, as well as comparison with studies of other species with an emphasis on the Cook Strait region. Phylogeographic patterns often differ widely between species, even for congeners with similar characteristics (Goldstien 2005; Goldstien et al. 2006; Knox et al. 2011). Increasing the breadth of species, sample sites and markers examined in the literature will improve understanding of the processes structuring populations (Ross et al. 2009; Gardner et al. 2010).

C. virgata has pronounced variation in shell morphology between populations in the northern North Island, but less variation further south (Fig. 2.7A-G). Powell (1952) distinguished populations from the east coast north of the Bay 
of Islands as a subspecies, C. virgata brookesi Powell, 1952 (holotype: Fig. 2.7E), based on colour pattern (see below), either ignoring or unaware of diverse populations on the west coast of Northland (Fig. 2.7F, G). Shells of the various forms, including C. virgata brookesi and the nominal subspecies, appear to intergrade, leading to confusion regarding the name to apply to each population or if the continued maintenance of subspecies is justified.

\section{Materials and methods}

\section{Sampling and specimen handling}

Over 1,000 specimens of C. virgata were examined in 230 lots at the Museum of New Zealand Te Papa Tongarewa (NMNZ) (Fig. 2.2C). Samples were collected by searching the intertidal zone on the turn of the low tide. Where $C$. maculosa or C. virgata were difficult to find or seemingly absent, mussels were broken and scattered in pools in an attempt to attract them. Samples for molecular analyses were stored in $98 \%$ ethanol and vouchers deposited at NMNZ (Table 2.1). Photoshop CS6 (Adobe) was used for image clear-cutting and plate assembly.

\section{DNA preparation, sequencing and alignment}

Approximately $1 \mathrm{~mm}^{3}$ of foot tissue was digested at $56^{\circ} \mathrm{C}$ for 2 hours in 600 $\mu \mathrm{L}$ of extraction solution comprising $10 \mathrm{mM}$ Tris $\mathrm{pH}$ 8.0, $10 \mathrm{mM}$ EDTA, 50 $\mathrm{mM} \mathrm{NaCl}, 0.2 \%$ sodium dodecyl sulphate, and $1 \mu \mathrm{g} / \mu \mathrm{l}$ proteinase-K. The digested tissue was purified using phenol-chloroform extraction (Sambrook et al. 1989), precipitated with 2.5 volumes of $100 \%$ ethanol and $3 \mathrm{mM}$ sodium acetate $\mathrm{pH}$ 5.2. The precipitates were then pelleted by centrifugation, washed with $70 \%$ ethanol, dried, and re-suspended in TE buffer (10 mM Tris $\mathrm{pH} 8.0,1$ mM EDTA). DNA yields were quantified using a NanoDrop 1000 spectrophotometer. 
Portions of the mitochondrial genes CO1 and 16S rRNA (16S) and the nuclear gene 18S rRNA (18S) were amplified by PCR using the primers LCO1490 and HCO2198 (Folmer et al. 1994; CO1), 16Sar and 16Sbr (Simon et al. 1994; 16S), 18S-5 (Winnepenninckx et al. 1998; 18S) and 18S1100R (Williams et al. 2004; 18S). Each $10 \mu 1$ PCR solution contained 67 mM Tri$\mathrm{HCl} \mathrm{pH} 8.8,16 \mathrm{mM}\left(\mathrm{NH}_{4}\right)_{2} \mathrm{SO}_{4}, 3 \mathrm{mM}$ of $\mathrm{MgCl}_{2}, 0.6 \mathrm{mg} / \mathrm{mL}$ of BSA, $0.1 \mu \mathrm{M}$ each forward and reverse primer, $0.4 \mathrm{mM} \mathrm{dNTPs}, 0.05 \mathrm{U} / \mu \mathrm{L}$ of taq polymerase (Biostor), and $50 \mathrm{ng} / \mu \mathrm{L}$ of DNA template. Thermal cycling conditions for $\mathrm{CO} 1$ and $16 \mathrm{~S}$ were: $180 \mathrm{~s}$ at $95^{\circ} \mathrm{C}$ followed by 40 cycles of $95^{\circ} \mathrm{C}$ for $35 \mathrm{~s}, 50^{\circ} \mathrm{C}$ for $35 \mathrm{~s}$ and $72^{\circ} \mathrm{C}$ for $45 \mathrm{~s}$. A final extension followed of $72^{\circ} \mathrm{C}$ for 10 minutes. The $18 \mathrm{~S}$ thermal cycling conditions followed Donald et al. (2015).

The resultant PCR products were electrophoresed on an agarose gel, stained with ethidium bromide and visualised using UV light. Amplified PCR products were purified using ExoSAP-IT (Amersham Parmacia Biotech) and their DNA sequence determined using a 3730xl Genetic Analyser (Applied Biosystems) at Macrogen Inc. (Seoul, South Korea).

Previously published DNA sequences originating from Donald et al. (2015) were sourced from Genbank (Table 2.2). CO1 sequences were trimmed to 610 bp for population genetic analyses to match the Fleming et al. (in review) dataset. For phylogenies, the $\mathrm{CO} 1,16 \mathrm{~S}$ and $18 \mathrm{~S}$ sequences were trimmed to 528, 457 and 711 bp respectively to match available sequences on Genbank. All DNA sequences were aligned using the Geneious (version 8.0.5) (Biomatters Ltd.) alignment option (Kearse et al. 2012).

\section{Phylogenetic trees}

Maximum likelihood trees were generated using the PhyML (version 2.2.0) (Guindon and Gascuel 2003; Guindon et al. 2010) plug-in in Geneious with 500 bootstrap replications. Bayesian trees were generated using the MrBAYES (version 3.2.6) (Huelsenback and Ronquist 2001) plug-in in Geneious with 1,100,000 MCMC replications, of which 100,000 were 
discarded as burn-in. Phylogenetic trees were edited in FigTree (version 1.4.3) (Rambaut and Drummond 2012) and formatted using Photoshop.

\section{Statistical analyses}

Diversity indices (Table 2.1) were calculated using DnaSP (Version 5.10) (Librado and Rozas 2009) and included the number of segregating sites (S), nucleotide diversity $(\pi)$, haplotype diversity $\left(\mathrm{H}_{\mathrm{D}}\right)$ and the average number of nucleotide substitutions between sequences (k). Tajima's $D$ (Tajima 1989) and Fu's $F_{S}(\mathrm{Fu} 1997)$ neutrality test statistics, Harpending's raggedness statistic ( rg) (Harpending et al. 1993; Harpending 1994), sum of squared deviations (SSD), tau $(\tau), \theta_{0}$ and $\theta_{1}$ (supplementary Tables 1,2 ) were calculated in Arlequin (Version 3.5.2.2) (Excoffier and Lischer 2010) for each sample location.

Median joining haplotype networks were made in PopART (version 1.7; http://popart.otago.ac.nz/) and coloured according to sample locations that were clustered a priori on the basis of region and unique haplotypes (Figs. 2.1A, B, 2.2A, B, 2.3). Rarefaction analyses (Fig. 2.4A, B) performed in Analytic Rarefaction (version 1.3; Holland, 2003) were used to approximate the proportion of the total (true) haplotype diversity that was detected with the present samples.

Pairwise genetic differences between sample locations, using the fixation index $\Phi_{\mathrm{ST}}$, were calculated by both haplotype frequencies and pairwise genetic differences (supplementary Tables 3-6) in Arlequin using 10,000 permutations, to assay the degree of gene-flow between locations. Populations were assigned a priori to regional groups (Tables $2.3,2.4$ ) for analyses of the molecular variance (AMOVA). AMOVAs were performed using Arlequin, using both haplotype frequencies and pairwise genetic differences, to estimate the variance components and $\Phi_{\mathrm{ST}}$ values within and between regions (Tables $2.3,2.4)$. The high proportion of private haplotypes in both the C. maculosa and $C$. virgata datasets may have led to many a priori combinations yielding 
statistically significant results. Significance was determined using 10,000 permutations.

\section{Abbreviations used in the text}

AM - Auckland War Memorial Museum, Auckland, New Zealand; BP before present; GNS - Institute of Geological and Nuclear Sciences, Lower Hutt, New Zealand; MHNG - Muséum d'Histoire Naturelle de la Ville de Genève, Geneva, Switzerland; MNHN - Muséum National d'Histoire Naturelle, Paris, France; NHMUK - The Natural History Museum, London, England; NMNZ - Museum of New Zealand Te Papa Tongarewa, Wellington, New Zealand; TMAG - Tasmanian Museum and Art Gallery, Hobart, Australia; VUW - Victoria University of Wellington, New Zealand. Unless specified, material examined is at NMNZ (six-digit registration numbers prefixed 'M.').

\section{Results}

This study added $126 \mathrm{CO} 1$ sequences of $C$. maculosa from eight new sample localities to the Fleming et al. (in review) dataset giving a total of 658 sequences from 30 localities (Table 2.1) for analyses. These featured 47 haplotypes, of which 33 were private to one locality, and 43 segregating sites (Table 2.1). For $C$. virgata, $156 \mathrm{CO} 1$ sequences and nine new sample sites were added, giving a total of 497 sequences from 22 localities (Table 2.1). Present were 41 haplotypes, of which 31 were private to one locality, and 45 segregating sites (Table 2.1).

In C. maculosa, $23 \%$ of sequences from Nelson fall into a haplogroup predominantly comprising sequences from Hauraki Gulf and Bay of Plenty samples. All other sequences from populations in the South Island, from Cape Palliser to New Plymouth in the southern North Island, and the Chatham Islands, form a private "southern" haplogroup comprised of several haplotypes 
one or two mutational steps divergent from a predominant central haplotype (Fig. 2.1A). Samples from the Chatham Islands form a private sub-group to this "southern" haplogroup. This sub-group comprises one haplotype $(n=5)$ a single mutational step divergent from the predominant central haplotype of the "southern" haplogroup, and a second haplotype $(\mathrm{n}=1)$ an additional mutational step divergent (Fig. 2.1A).

Both haplotypes present in the South Island in $C$. virgata are also present in the North Island. One is represented in the South Island by one sequence from Nelson and in the North Island by one sequence from the Hauraki Gulf and many sequences from Wellington (Fig. 2.2A). The second haplotype present in the South Island, represented by 89 of the 90 sequences, also occurs at a high frequency in the Hauraki Gulf. This haplotype forms the centre of a recently expanded ('star-shaped') haplogroup (Fig. 2.2A) that has greater diversity in- and probably originated from- the north-eastern North Island (see below).

Populations of $C$. virgata from the lower North Island form two distinct haplogroups (Fig. 2.2A). One comprises two private haplotypes. The other features a single haplotype, represented by many sequences from Wellington and a single sequence from both the Hauraki Gulf and Nelson (Fig. 2.2A).

Comparatively few samples $(\mathrm{n}=5)$ were available from Maunganui Bluff (Table 2.1). Samples of C. virgata from Maunganui Bluff and Ahipara form a private haplogroup (Fig. 2.2A) that comprises a common shared haplotype and another private to Ahipara. Five private haplotypes were present in samples from Parengarenga Harbour, forming a private haplogroup (Fig. 2.2A). The lack of shared haplotypes between many northern populations means that the geographic scale of haplotype transitions cannot be discerned in the region.

Haplotype and nucleotide diversities, and the distributions of haplotypes between populations that were sampled for this study, appear to be concordant with those of populations from the Fleming et al. (in review) dataset. While most haplogroups are private to a region or have regional affinities, most 
regions have multiple haplogroups that often do not cluster together (Figs. 2.1A, 2.2A).

The $16 \mathrm{~S}$ dataset was smaller and most DNA sequences were from north of Cape Rodney (Table 2.1). The 16S haplotype network map (Fig. 2.3A) suggests some north/south structure and there appears to be regional structure, although sample sizes were too low to draw conclusions (Fig. 2.3B). No sampled locality had more than two haplotypes or haplotypes more than one mutational step divergent (Fig. 2.3A).

$18 \mathrm{~S}$ is a more highly conserved gene and was uninformative for within species analyses 
Table 2.1. Sample location data, summary statistics and haplotype lists. $n=$ sample size; $s=$ number of segregating sites; $h_{p}=$ number of private haplotypes; $h_{n}=$ number of haplotypes; $h_{d}=$ haplotype diversity (standard deviation); $\pi=$ nucleotide diversity (standard deviation); $\mathrm{k}=$ average number of nucleotide substitutions. Rows in bold denote samples originating from this study. The rest comprise the dataset of Fleming et al. (in review). Each haplotype is identified by a number, '6(20)', for example, would refer to 20 sequences of haplotype ' 6 '. '*' denotes haplotypes private to that site; '\#' denotes haplotypes private to one site.

\begin{tabular}{|c|c|c|c|c|c|c|c|c|c|c|c|}
\hline $\begin{array}{l}\text { Species } \\
\text { (voucher) }\end{array}$ & $\begin{array}{l}\text { Site } \\
\text { code }\end{array}$ & Location & Co-ordinates & $\mathrm{n}$ & $\mathrm{s}$ & $\mathrm{h}_{\mathrm{p}}$ & $\mathrm{h}_{\mathrm{n}}$ & $\mathrm{h}_{\mathrm{d}}(\mathrm{sd})$ & $\pi(\mathrm{sd})$ & $\mathrm{k}$ & Haplotypes (n) '*' denotes private \\
\hline C. maculosa & $\mathrm{AMB}$ & $\begin{array}{l}\text { Mathesons } \\
\text { Bay }\end{array}$ & $\begin{array}{l}36^{\circ} 18.00^{\prime} \mathrm{S} \\
174^{\circ} 48.00^{\prime} \mathrm{E}\end{array}$ & 10 & 5 & 1 & 4 & $\begin{array}{l}0.778 \\
(0.091)\end{array}$ & $\begin{array}{l}0.0030 \\
(0.001)\end{array}$ & 1.800 & $3(3), 4(1)^{*}, 5(2), 6(4)$ \\
\hline C. maculosa & ASB & Snells Beach & $\begin{array}{l}36^{\circ} 25.00^{\prime} \mathrm{S} \\
174^{\circ} 44.00^{\prime} \mathrm{E}\end{array}$ & 20 & 3 & 1 & 4 & $\begin{array}{l}0.284 \\
(0.128)\end{array}$ & $\begin{array}{l}0.0006 \\
(<0.001)\end{array}$ & 0.389 & $3(1), 5(1), 6(17), 11(1)^{*}$ \\
\hline C. maculosa & $\mathrm{ARB}$ & Red Beach & $\begin{array}{l}36^{\circ} 35.00^{\prime} \mathrm{S} \\
174^{\circ} 42.00^{\prime} \mathrm{E}\end{array}$ & 23 & 4 & 2 & 4 & $\begin{array}{l}0.320 \\
(0.121)\end{array}$ & $\begin{array}{l}0.0007 \\
(<0.000)\end{array}$ & 0.427 & $5(2), 6(19), 9(1)^{*}, 10(1)^{*}$ \\
\hline C. maculosa & $\mathrm{AAB}$ & Army Bay & $\begin{array}{l}36^{\circ} 35.00^{\prime} \mathrm{S} \\
174^{\circ} 48.00^{\prime} \mathrm{E}\end{array}$ & 24 & 3 & 1 & 4 & $\begin{array}{l}0.370 \\
(0.117)\end{array}$ & $\begin{array}{l}0.0006 \\
(<0.000)\end{array}$ & 0.395 & $5(1), 6(19), 7(1), 8(3)^{*}$ \\
\hline C. maculosa & $\mathrm{BBO}$ & Bowentown & $\begin{array}{l}37^{\circ} 28.00^{\prime} \mathrm{S} \\
175^{\circ} 59.00^{\prime} \mathrm{E}\end{array}$ & 11 & 6 & 0 & 4 & $\begin{array}{l}0.491 \\
(0.175)\end{array}$ & $\begin{array}{l}0.0034 \\
(0.001)\end{array}$ & 2.073 & 14(8), 20(1), 38(1), 39(1) \\
\hline C. maculosa & BMM & $\begin{array}{l}\text { Mount } \\
\text { Maunganui }\end{array}$ & $\begin{array}{l}37^{\circ} 37.00^{\prime} \mathrm{S} \\
176^{\circ} 10.00^{\prime} \mathrm{E}\end{array}$ & 10 & 5 & 3 & 5 & $\begin{array}{l}0.756 \\
(0.130)\end{array}$ & $\begin{array}{l}0.0030 \\
(0.001)\end{array}$ & 1.822 & $\begin{array}{l}6(5), 14(1), 15(2)^{*}, 16(1)^{*}, \\
17(1)^{*}\end{array}$ \\
\hline C. maculosa & BMA & Maketu & $\begin{array}{l}37^{\circ} 44.00^{\prime} \mathrm{E} \\
176^{\circ} 27.00^{\prime} \mathrm{E}\end{array}$ & 26 & 5 & 2 & 6 & $\begin{array}{l}0.717 \\
(0.078)\end{array}$ & $\begin{array}{l}0.0015 \\
(<0.000)\end{array}$ & 0.914 & $\begin{array}{l}5(6), 4(13), 18(4)^{*}, 19(2), 20(2), \\
21(1)^{*}\end{array}$ \\
\hline C. maculosa & $\mathrm{BOM}$ & Omaio & $\begin{array}{l}37^{\circ} 48.00^{\prime} \mathrm{S} \\
177^{\circ} 37.00^{\prime} \mathrm{E}\end{array}$ & 31 & 8 & 4 & 7 & $\begin{array}{l}0.774 \\
(0.056)\end{array}$ & $\begin{array}{l}0.0038 \\
(<0.001)\end{array}$ & 2.288 & $\begin{array}{l}6(5), 7(4), 14(13), 22(1)^{*}, 23(5)^{*} \\
24(1)^{*}, 25(2)^{*}\end{array}$ \\
\hline C. maculosa & GTA & Te Araroa & $\begin{array}{l}37^{\circ} 37.00^{\prime} \mathrm{S} \\
178^{\circ} 23.00^{\prime} \mathrm{E}\end{array}$ & 29 & 3 & 1 & 3 & $\begin{array}{l}0.394 \\
(0.094)\end{array}$ & $\begin{array}{l}0.0018 \\
(<0.001)\end{array}$ & 1.099 & $6(1), 19(6), 26(22)^{*}$ \\
\hline C. maculosa & GTT & Tatapouri & $\begin{array}{l}38^{\circ} 39.00^{\prime} \mathrm{S} \\
178^{\circ} 08.00^{\prime} \mathrm{E}\end{array}$ & 29 & 4 & 0 & 2 & $\begin{array}{l}0.069 \\
(0.063)\end{array}$ & $\begin{array}{l}0.0005 \\
(<0.001)\end{array}$ & 0.276 & $5(1), 27(28)$ \\
\hline C. maculosa & GMA & Mahia & $\begin{array}{l}39^{\circ} 05.00^{\prime} \mathrm{S} \\
177^{\circ} 55.00^{\prime} \mathrm{E}\end{array}$ & 25 & 8 & 1 & 4 & $\begin{array}{l}0.360 \\
(0.117)\end{array}$ & $\begin{array}{l}0.0023 \\
(0.001)\end{array}$ & 1.427 & $6(1), 27(20), 28(2), 36(2)^{*}$ \\
\hline
\end{tabular}


Table 2.1. Continued...

\begin{tabular}{|c|c|c|c|c|c|c|c|c|c|c|c|}
\hline $\begin{array}{l}\text { Species } \\
\text { (voucher) }\end{array}$ & $\begin{array}{l}\text { Site } \\
\text { code }\end{array}$ & Location & Co-ordinates & $\mathrm{n}$ & $\mathrm{S}$ & $\mathrm{h}_{\mathrm{p}}$ & $\mathrm{h}_{\mathrm{n}}$ & $\mathrm{h}_{\mathrm{d}}(\mathrm{sd})$ & $\pi(\mathrm{sd})$ & $\mathrm{k}$ & Haplotypes (n) '*' denotes private \\
\hline C. maculosa & HPA & Napier & $\begin{array}{l}39^{\circ} 28.00^{\prime} \mathrm{S} \\
176^{\circ} 53.00^{\prime} \mathrm{E}\end{array}$ & 24 & 1 & 1 & 2 & $\begin{array}{l}0.083 \\
(0.075)\end{array}$ & $\begin{array}{l}0.0001 \\
(<0.001)\end{array}$ & 0.083 & $28(23), 37(1)^{*}$ \\
\hline $\begin{array}{l}\text { C. maculosa } \\
\text { (M.162486) }\end{array}$ & HPB & $\begin{array}{l}\text { Pourerere } \\
\text { Beach }\end{array}$ & $\begin{array}{l}40^{\circ} 07.00^{\prime} \mathrm{S} \\
176^{\circ} 52.00^{\prime} \mathrm{E}\end{array}$ & 24 & 4 & 0 & 2 & $\begin{array}{l}0.083 \\
(0.075)\end{array}$ & $\begin{array}{l}0.0006 \\
(<0.001)\end{array}$ & 0.333 & $6(1), 28(23)$ \\
\hline C. maculosa & HWB & $\begin{array}{l}\text { Whangaehu } \\
\text { Beach }\end{array}$ & $\begin{array}{l}40^{\circ} 24.00^{\prime} \mathrm{S} \\
176^{\circ} 38.00^{\prime} \mathrm{E}\end{array}$ & 23 & 9 & 0 & 4 & $\begin{array}{l}0.605 \\
(0.079)\end{array}$ & $\begin{array}{l}0.0063 \\
(0.001)\end{array}$ & 3.850 & $27(13), 28(7), 38(1), 39(2)$ \\
\hline C. maculosa & WCS & Castle Point & $\begin{array}{l}40^{\circ} 51.00^{\prime} \mathrm{S} \\
176^{\circ} 14.00^{\prime} \mathrm{E}\end{array}$ & 28 & 9 & 3 & 5 & $\begin{array}{l}0.717 \\
(0.042)\end{array}$ & $\begin{array}{l}0.0065 \\
(0.001)\end{array}$ & 3.963 & $\begin{array}{l}27(9), 28(11), 29(2)^{*}, 30(6)^{*} \\
47 \mathrm{k}(1)^{*}\end{array}$ \\
\hline C. maculosa & WCP & Cape Palliser & $\begin{array}{l}41^{\circ} 36.00^{\prime} \mathrm{S} \\
175^{\circ} 17.00^{\prime} \mathrm{E}\end{array}$ & 27 & 1 & 1 & 2 & $\begin{array}{l}0.142 \\
(0.086)\end{array}$ & $\begin{array}{l}0.0002 \\
(<0.001)\end{array}$ & 0.142 & $1(25), 35(2)^{*}$ \\
\hline C. maculosa & WMA & Makara & $\begin{array}{l}41^{\circ} 13.00^{\prime} \mathrm{S} \\
174^{\circ} 42.00^{\prime} \mathrm{E}\end{array}$ & 20 & 0 & 0 & 1 & - & - & - & $1(20)$ \\
\hline C. maculosa & WPH & Point Howard & $\begin{array}{l}41^{\circ} 15.00^{\prime} \mathrm{S} \\
174^{\circ} 54.00^{\prime} \mathrm{E}\end{array}$ & 21 & 0 & 0 & 1 & - & - & - & $1(21)$ \\
\hline C. maculosa & WMP & Moa Point & $\begin{array}{l}41^{\circ} 20.00^{\prime} \mathrm{S} \\
174^{\circ} 48.00^{\prime} \mathrm{E}\end{array}$ & 19 & 1 & 1 & 2 & $\begin{array}{l}0.199 \\
(0.112)\end{array}$ & $\begin{array}{l}0.0003 \\
(<0.001)\end{array}$ & 0.199 & $1(17), 2(2)^{*}$ \\
\hline C. maculosa & TMA & Marokopa & $\begin{array}{l}38^{\circ} 19.00^{\prime} \mathrm{S} \\
174^{\circ} 42.00^{\prime} \mathrm{E}\end{array}$ & 31 & 0 & 1 & 1 & - & - & - & $13(31)^{*}$ \\
\hline C. maculosa & TNP & New Plymouth & $\begin{array}{l}39^{\circ} 03.00^{\prime} \mathrm{S} \\
174^{\circ} 03.00^{\prime} \mathrm{E}\end{array}$ & 31 & 1 & 1 & 2 & $\begin{array}{l}0.280 \\
(0.090)\end{array}$ & $\begin{array}{l}0.0005 \\
(<0.001)\end{array}$ & 0.280 & $1(26), 12(5)^{*}$ \\
\hline $\begin{array}{l}\text { C. maculosa } \\
\text { (M.129798) }\end{array}$ & WCM & Te Hapu & $\begin{array}{l}40^{\circ} 36.92 ' \mathrm{~S} \\
172^{\circ} 28.72^{\prime} \mathrm{E}\end{array}$ & 20 & 1 & 2 & 3 & $\begin{array}{l}0.195 \\
(0.115)\end{array}$ & $\begin{array}{l}0.0003 \\
(<0.001)\end{array}$ & 0.200 & $1(18), 45 \mathrm{k}(1)^{*}, 46 \mathrm{k}(1)^{*}$ \\
\hline $\begin{array}{l}\text { C. maculosa } \\
\text { (M.302312) }\end{array}$ & PRM & Patons Rock & $\begin{array}{l}40^{\circ} 47.19^{\prime} \mathrm{S} \\
172^{\circ} 45.94^{\prime} \mathrm{E}\end{array}$ & 20 & $\mathbf{0}$ & $\mathbf{0}$ & 1 & - & - & - & $1(20)$ \\
\hline $\begin{array}{l}\text { C. maculosa } \\
\text { (M.321239) }\end{array}$ & KTM & Kaiteriteri & $\begin{array}{l}41^{\circ} 02.10^{\prime} \mathrm{S} \\
173^{\circ} 01.42^{\prime} \mathrm{E}\end{array}$ & 20 & $\mathbf{0}$ & $\mathbf{0}$ & 1 & - & - & - & $1(20)$ \\
\hline C. maculosa & NEL & Nelson & $\begin{array}{l}41^{\circ} 16.00^{\prime} \mathrm{S} \\
173^{\circ} 15.00^{\prime} \mathrm{E}\end{array}$ & 26 & 8 & 4 & 6 & $\begin{array}{l}0.609 \\
(0.102)\end{array}$ & $\begin{array}{l}0.0031 \\
(0.001)\end{array}$ & 1.874 & $\begin{array}{l}1(16), 5(1), 6(3), 31(2), 32(3), \\
33(1)\end{array}$ \\
\hline
\end{tabular}


Table 2.1. Continued...

\begin{tabular}{|c|c|c|c|c|c|c|c|c|c|c|c|}
\hline $\begin{array}{l}\text { Species } \\
\text { (voucher) }\end{array}$ & $\begin{array}{l}\text { Site } \\
\text { code }\end{array}$ & Location & Co-ordinates & $\mathrm{n}$ & $\mathrm{s}$ & $\mathrm{h}_{\mathrm{p}}$ & $\mathrm{h}_{\mathrm{n}}$ & $\mathrm{h}_{\mathrm{d}}(\mathrm{sd})$ & $\pi(\mathrm{sd})$ & $\mathrm{k}$ & Haplotypes (n) ' *' denotes private \\
\hline $\begin{array}{l}\text { C. maculosa } \\
\text { (M.316880) }\end{array}$ & PBM & Picton & $\begin{array}{l}41^{\circ} 17.30^{\prime} \mathrm{S}, \\
174^{\circ} 00.47^{\prime} \mathrm{E}\end{array}$ & 20 & 1 & 1 & 2 & $\begin{array}{l}0.100 \\
(0.088)\end{array}$ & $\begin{array}{l}0.0002 \\
(<0.001)\end{array}$ & 0.100 & 1(19), 44k(1)* \\
\hline $\begin{array}{l}\text { C. maculosa } \\
(\mathrm{M.106630})\end{array}$ & MBM & $\begin{array}{l}\text { Marfells } \\
\text { Beach }\end{array}$ & $\begin{array}{l}4^{\circ} 43.33 ' \mathrm{~S}, \\
174^{\circ} 13.42^{\prime} \mathrm{E}\end{array}$ & 20 & 1 & 1 & 2 & $\begin{array}{l}0.100 \\
(0.088)\end{array}$ & $\begin{array}{l}0.0002 \\
(<0.001)\end{array}$ & 0.100 & 1(19), 43k(1)* \\
\hline $\begin{array}{l}\text { C. maculosa } \\
\text { (M.108444) }\end{array}$ & KKM & Kaikoura & $\begin{array}{l}42^{\circ} 24.76^{\prime} \mathrm{S}, \\
173^{\circ} 41.43^{\prime} \mathrm{E}\end{array}$ & 20 & $\mathbf{0}$ & $\mathbf{0}$ & 1 & - & - & - & $1(20)$ \\
\hline $\begin{array}{l}\text { C. maculosa } \\
\text { (M.114548) }\end{array}$ & CHM & Purau Bay & $\begin{array}{l}43^{\circ} 38.22^{\prime} \mathrm{S}, \\
172^{\circ} 44.87^{\prime} \mathrm{E}\end{array}$ & 20 & 1 & 1 & 2 & $\begin{array}{l}0.100 \\
(0.088)\end{array}$ & $\begin{array}{l}0.0002 \\
(<0.001)\end{array}$ & 0.100 & 1(19), 40k(1)* \\
\hline $\begin{array}{l}\text { C. maculosa } \\
\text { (M.315669) }\end{array}$ & CIW & Waitangi & $\begin{array}{l}43^{\circ} 56.70 ’ \mathrm{~S} \\
176^{\circ} 33.80^{\prime} \mathrm{W}\end{array}$ & 4 & 1 & 1 & 2 & $\begin{array}{l}0.500 \\
(0.265)\end{array}$ & $\begin{array}{l}0.0008 \\
(<0.001)\end{array}$ & 0.500 & $41 \mathrm{k}(3), 42 \mathrm{k}(1)^{*}$ \\
\hline $\begin{array}{l}\text { C. maculosa } \\
\text { (M.315642) }\end{array}$ & CIO & Owenga & $\begin{array}{l}4^{\circ} 01.70 ' \mathrm{~S} \\
1^{\circ} 6^{\circ} 21.00 ' \mathrm{~W}\end{array}$ & 2 & $\mathbf{0}$ & $\mathbf{0}$ & 1 & - & - & - & $41 k(2)$ \\
\hline C. maculosa & - & $\begin{array}{l}\text { All sample } \\
\text { locations }\end{array}$ & - & 658 & 43 & $33^{\#}$ & 47 & $\begin{array}{l}0.801 \\
(0.013)\end{array}$ & $\begin{array}{l}0.0057 \\
(<0.001)\end{array}$ & 3.469 & $\begin{array}{l}1(260), 2(2)^{\#}, 3(4), 4(1)^{\#}, 5(11), \\
6(88), 7(5), 8(15)^{\#}, 9(1)^{\#}, 10(1)^{\#}, \\
11(1)^{\#}, 12(5)^{\#}, 13(31)^{\#}, 14(22), \\
15(2)^{\#}, 16(1)^{\#}, 17(1)^{\#}, 18(4)^{\#}, \\
19(8), 20(3), 21(1)^{\#}, 22(1)^{\#}, \\
23(5)^{\#}, 24(1)^{\#}, 25(2)^{\#}, 26(22)^{\#}, \\
27(69), 28(66), 29(2)^{\#}, 30(6)^{\#}, \\
31(2)^{\#}, 32(3)^{\#}, 33(1)^{\#}, 34(1)^{\#}, \\
35(2)^{\#}, 36(2)^{\#}, 37(1)^{\#}, 38(3), \\
39(2), 40 \mathrm{k}(1)^{\#}, 41 \mathrm{k}(5), 42 \mathrm{k}(2)^{\#}, \\
43 \mathrm{k}(1)^{\#}, 44 \mathrm{k}(1)^{\#}, 45 \mathrm{k}(1)^{\#}, \\
46 \mathrm{k}(1)^{\#}, 47 \mathrm{k}(1)^{\#}\end{array}$ \\
\hline $\begin{array}{l}\text { C. virgata } \\
\text { (M.100905) }\end{array}$ & MAV & $\begin{array}{l}\text { Maunganui } \\
\text { Bluff }\end{array}$ & $\begin{array}{l}35^{\circ} 46.08 ' \mathrm{~S}, \\
173^{\circ} 34.10^{\prime} \mathrm{E}\end{array}$ & 5 & $\mathbf{0}$ & $\mathbf{0}$ & 1 & - & - & - & $22(5)$ \\
\hline $\begin{array}{l}\text { C. virgata } \\
\text { (M.122735) }\end{array}$ & AHV & Ahipara & $\begin{array}{l}35^{\circ} 10.50^{\prime} \mathrm{S}, \\
173^{\circ} 07.05^{\prime} \mathrm{E}\end{array}$ & 20 & 1 & 1 & 2 & $\begin{array}{l}0.100 \\
(0.088)\end{array}$ & $\begin{array}{l}0.0002 \\
(<0.001)\end{array}$ & 0.100 & $22(19), 23(1)^{*}$ \\
\hline
\end{tabular}


Table 2.1. Continued...

\begin{tabular}{|c|c|c|c|c|c|c|c|c|c|c|c|}
\hline $\begin{array}{l}\text { Species } \\
\text { (voucher) }\end{array}$ & $\begin{array}{l}\text { Site } \\
\text { code }\end{array}$ & Location & Co-ordinates & $\mathrm{n}$ & $\mathrm{s}$ & $\mathrm{h}_{\mathrm{p}}$ & $\mathrm{h}_{\mathrm{n}}$ & $\mathrm{h}_{\mathrm{d}}(\mathrm{sd})$ & $\pi(\mathrm{sd})$ & $\mathrm{k}$ & Haplotypes (n) '*' denotes private \\
\hline $\begin{array}{l}\text { C. virgata } \\
\text { (M.166286) }\end{array}$ & PAV & Paua & $\begin{array}{l}34^{\circ} 31.53 ' \mathrm{~S} \\
172^{\circ} 57.00^{\prime} \mathrm{E}\end{array}$ & 20 & 5 & 5 & 5 & $\begin{array}{l}0.600 \\
(0.101)\end{array}$ & $\begin{array}{l}0.0016 \\
(<0.001)\end{array}$ & 0.974 & $\begin{array}{l}24(12)^{*}, 25(1)^{*}, 26(1)^{*}, 27(5)^{*} \\
28(1)^{*}\end{array}$ \\
\hline $\begin{array}{l}\text { C. virgata } \\
(\text { M.100890) }\end{array}$ & BBV & Bland Bay & $\begin{array}{l}35^{\circ} 21.03 ' \mathrm{~S} \\
174^{\circ} 22.58 ' \mathrm{E}\end{array}$ & 12 & 12 & 2 & 4 & $\begin{array}{l}0.773 \\
(0.069)\end{array}$ & $\begin{array}{l}0.0094 \\
(0.002)\end{array}$ & 5.742 & $4(4), 29(4)^{*}, 30(3)^{*}, 31(1)$ \\
\hline $\begin{array}{l}\text { C. virgata } \\
(\mathrm{M.092949)}\end{array}$ & NGV & Ngunguru & $\begin{array}{l}35^{\circ} 38.22^{\prime} \mathrm{S}, \\
174^{\circ} 31.83 ' \mathrm{E}\end{array}$ & 20 & 16 & 5 & 8 & $\begin{array}{l}0.747 \\
(0.097)\end{array}$ & $\begin{array}{l}0.0046 \\
(0.002)\end{array}$ & 2.789 & $\begin{array}{l}4(10), 31(1), 32(1), 33(2)^{*}, \\
34(2)^{*}, 35(1)^{*}, 36(2)^{*}, 37(1)^{*}\end{array}$ \\
\hline $\begin{array}{l}\text { C. virgata } \\
(\mathrm{M.105361)}\end{array}$ & MGV & $\begin{array}{l}\text { McGregors } \\
\text { Bay }\end{array}$ & $\begin{array}{l}35^{\circ} 49.68 ' \mathrm{~S}, \\
174^{\circ} 30.97 ' \mathrm{E}\end{array}$ & 17 & 17 & 4 & 5 & $\begin{array}{l}0.772 \\
(0.057)\end{array}$ & $\begin{array}{l}\mathbf{0 . 0 1 3 0} \\
(0.001)\end{array}$ & 7.912 & $\begin{array}{l}32(4), 38(6)^{*}, 39(5)^{*}, 40(1)^{*} \\
41(1)^{*}\end{array}$ \\
\hline C. virgata & AMB & $\begin{array}{l}\text { Mathesons } \\
\text { Bay }\end{array}$ & $\begin{array}{l}36^{\circ} 18.00^{\prime} \mathrm{S} \\
174^{\circ} 48.00^{\prime} \mathrm{E}\end{array}$ & 25 & 0 & 0 & 1 & - & - & - & $4(25)$ \\
\hline C. virgata & ASB & Snells Beach & $\begin{array}{l}36^{\circ} 25.00^{\prime} \mathrm{S} \\
174^{\circ} 44.00^{\prime} \mathrm{E}\end{array}$ & 24 & 4 & 4 & 5 & $\begin{array}{l}0.312 \\
(0.121)\end{array}$ & $\begin{array}{l}0.0006 \\
(<0.001)\end{array}$ & 0.333 & $\begin{array}{l}4(20), 10(1)^{*}, 11(1)^{*}, 12(1)^{*}, \\
13(1)^{*}\end{array}$ \\
\hline C. virgata & ARB & Red Beach & $\begin{array}{l}36^{\circ} 35.00^{\prime} \mathrm{S} \\
174^{\circ} 42.00^{\prime} \mathrm{E}\end{array}$ & 24 & 3 & 0 & 3 & $\begin{array}{l}0.163 \\
(0.099)\end{array}$ & $\begin{array}{l}0.0005 \\
(<0.001)\end{array}$ & 0.326 & 1(1), 4(22), 9(1) \\
\hline C. virgata & $\mathrm{AAB}$ & Army Bay & $\begin{array}{l}36^{\circ} 35.00^{\prime} \mathrm{S} \\
174^{\circ} 48.00^{\prime} \mathrm{E}\end{array}$ & 25 & 12 & 4 & 5 & $\begin{array}{l}0.680 \\
(0.067)\end{array}$ & $\begin{array}{l}0.0083 \\
(0.001)\end{array}$ & 5.067 & $4(12), 5(2)^{*}, 6(8)^{*}, 7(2)^{*}, 8(1)^{*}$ \\
\hline C. virgata & BMM & $\begin{array}{l}\text { Mount } \\
\text { Maunganui }\end{array}$ & $\begin{array}{l}37^{\circ} 37.00^{\prime} \mathrm{S} \\
176^{\circ} 10.00^{\prime} \mathrm{E}\end{array}$ & 29 & 5 & 0 & 2 & $\begin{array}{l}0.192 \\
(0.090)\end{array}$ & $\begin{array}{l}0.0016 \\
(0.001)\end{array}$ & 0.961 & $9(3), 14(26)$ \\
\hline C. virgata & BMA & Maketu & $\begin{array}{l}37^{\circ} 44.00^{\prime} \mathrm{E} \\
176^{\circ} 27.00^{\prime} \mathrm{E}\end{array}$ & 25 & 12 & 2 & 6 & $\begin{array}{l}0.647 \\
(0.073)\end{array}$ & $\begin{array}{l}0.0049 \\
(0.001)\end{array}$ & 2.993 & $\begin{array}{l}4(1), 9(8), 14(13), 15(1)^{*}, 16(1)^{*}, \\
17(1)\end{array}$ \\
\hline C. virgata & BOM & Omaio & $\begin{array}{l}37^{\circ} 48.00^{\prime} \mathrm{S} \\
177^{\circ} 37.00^{\prime} \mathrm{E}\end{array}$ & 41 & 3 & 1 & 3 & $\begin{array}{l}0.096 \\
(0.062)\end{array}$ & $\begin{array}{l}0.0003 \\
(<0.001)\end{array}$ & 0.193 & $14(1), 18(39)^{*}, 19(1)$ \\
\hline C. virgata & GTA & Te Araroa & $\begin{array}{l}37^{\circ} 37.00^{\prime} \mathrm{S} \\
178^{\circ} 23.00^{\prime} \mathrm{E}\end{array}$ & 39 & 9 & 2 & 6 & $\begin{array}{l}0.784 \\
(0.032)\end{array}$ & $\begin{array}{l}0.0067 \\
(<0.001)\end{array}$ & 4.084 & $\begin{array}{l}4(6), 14(13), 17(10), 19(7), \\
20(2)^{*}, 21(1)^{*}\end{array}$ \\
\hline C. virgata & GMA & Mahia & $\begin{array}{l}39^{\circ} 05.00^{\prime} \mathrm{S} \\
177^{\circ} 55.00^{\prime} \mathrm{E}\end{array}$ & 11 & 0 & 0 & 1 & - & - & - & $19(11)$ \\
\hline
\end{tabular}


Table 2.1. Continued...

\begin{tabular}{|c|c|c|c|c|c|c|c|c|c|c|c|}
\hline $\begin{array}{l}\begin{array}{l}\text { Species } \\
\text { (voucher) }\end{array}\end{array}$ & $\begin{array}{l}\text { Site } \\
\text { code }\end{array}$ & Location & Co-ordinates & $\mathrm{n}$ & $\mathrm{s}$ & $\mathrm{h}_{\mathrm{p}}$ & $\mathrm{h}_{\mathrm{n}}$ & $\mathrm{h}_{\mathrm{d}}(\mathrm{sd})$ & $\pi(\mathrm{sd})$ & $\mathrm{k}$ & Haplotypes (n) '*’ denotes private \\
\hline C. virgata & WPB & Pukerua Bay & $\begin{array}{l}41^{\circ} 01.00^{\prime} \mathrm{S}, \\
174^{\circ} 53.00^{\prime} \mathrm{E}\end{array}$ & 20 & 0 & 0 & 1 & - & - & - & $1(20)$ \\
\hline C. virgata & WPH & Point Howard & $\begin{array}{l}41^{\circ} 15.00^{\prime} \mathrm{S} \\
174^{\circ} 54.00^{\prime} \mathrm{E}\end{array}$ & 25 & 9 & 0 & 3 & $\begin{array}{l}0.410 \\
(0.111)\end{array}$ & $\begin{array}{l}0.0053 \\
(0.001)\end{array}$ & 3.260 & 1(19), 2(3), 3(3) \\
\hline C. virgata & WMP & Moa Point & $\begin{array}{l}41^{\circ} 20.00^{\prime} \mathrm{S} \\
174^{\circ} 48.00^{\prime} \mathrm{E}\end{array}$ & 25 & 10 & 0 & 3 & $\begin{array}{l}0.290 \\
(0.110)\end{array}$ & $\begin{array}{l}0.0040 \\
(0.002)\end{array}$ & 2.460 & $1(21), 2(1), 3(3)$ \\
\hline $\begin{array}{l}\text { C. virgata } \\
\text { (M.114916) }\end{array}$ & PRV & Patons Rock & $\begin{array}{l}40^{\circ} 47.19^{\prime} \mathrm{S} \\
172^{\circ} 45.94^{\prime} \mathrm{E}\end{array}$ & 20 & $\mathbf{0}$ & $\mathbf{0}$ & 1 & - & - & - & $4(20)$ \\
\hline $\begin{array}{l}\text { C. virgata } \\
\text { (321238) }\end{array}$ & KTV & Kaiteriteri & $\begin{array}{l}4^{\circ} 02.10^{\prime} \mathrm{S} \\
173^{\circ} 01.42^{\prime} \mathrm{E}\end{array}$ & 20 & $\mathbf{0}$ & $\mathbf{0}$ & 1 & - & - & - & $4(20)$ \\
\hline C. virgata & NEL & Nelson & $\begin{array}{l}41^{\circ} 16.00^{\prime} \mathrm{S}, \\
173^{\circ} 15.00^{\prime} \mathrm{E}\end{array}$ & 30 & 2 & 0 & 2 & $\begin{array}{l}0.067 \\
(0.061)\end{array}$ & $\begin{array}{l}0.0002 \\
(<0.001)\end{array}$ & 0.133 & $1(1), 4(29)$ \\
\hline $\begin{array}{l}\text { C. virgata } \\
\text { (M.316881) }\end{array}$ & PBV & Picton & $\begin{array}{l}41^{\circ} 17.30^{\prime} \mathrm{S} \\
174^{\circ} 00.47^{\prime} \mathrm{E}\end{array}$ & 20 & $\mathbf{0}$ & $\mathbf{0}$ & $\mathbf{1}$ & - & - & - & $4(20)$ \\
\hline C. virgata & - & $\begin{array}{l}\text { All sample } \\
\text { locations }\end{array}$ & - & 497 & 45 & $31^{\#}$ & 41 & $\begin{array}{l}0.817 \\
(0.014)\end{array}$ & $\begin{array}{l}0.0073 \\
(<0.001)\end{array}$ & 4.476 & $\begin{array}{l}\text { 1(62), 2(4), 3(6), 4(189), 5(2) }, \\
6(8)^{\#}, 7(2)^{\#}, 8(1)^{\#}, 9(12), 10(1)^{\#}, \\
11(1)^{\#}, 12(1)^{\#}, 13(1)^{\#}, 14(53), \\
15(1)^{\#}, 16(1)^{\#}, 17(11), 18(39)^{\#}, \\
19(19), 20(2)^{\#}, 21(1)^{\#}, 22(24), \\
23(1)^{\#}, 24(12)^{\#}, 25(1)^{\#}, 25(1)^{\#}, \\
26(1)^{\#}, 27(5)^{\#}, 28(1)^{\#}, 29(4)^{\#}, \\
30(3)^{\#}, 31(2), 32(5), 33(2)^{\#}, \\
34(2)^{\#}, 35(1)^{\#}, 36(2)^{\#}, 37(1)^{\#}, \\
38(6)^{\#}, 39(5)^{\#}, 40(1)^{\#}, 41(1)^{\#}\end{array}$ \\
\hline
\end{tabular}


Table 2.2. Samples used in molecular analyses and GenBank accession numbers where available. Rows in bold denote samples originating from this study. The rest originated from Donald et al. (2015) via GenBank.

\begin{tabular}{|c|c|c|c|c|c|c|}
\hline Species & ID & Registration & Location & $\begin{array}{l}\text { Accession \# } \\
(\mathrm{CO} 1)\end{array}$ & $\begin{array}{l}\text { Accession \# } \\
(16 \mathrm{~S})\end{array}$ & $\begin{array}{l}\text { Accession \# } \\
(18 \mathrm{~S})\end{array}$ \\
\hline Cominella acuminata Hutton, 1893 & 1 & M.317682 & Paratutae Island, Manukau Harbour & KP694160 & - & - \\
\hline C. acutinodosa (Reeve, 1846) & 2 & M.300749 & Broome, Western Australia & KP694120 & KР694068 & KP694163 \\
\hline C. adspersa (Bruguière, 1789) & 3 & M.317714 & Bucklands Beach, Hauraki Gulf & KР694149 & KP694101 & KР694196 \\
\hline C. adspersa (Bruguière, 1789) & 4 & M.300751 & Karaka Bay, Hauraki Gulf & KP694161 & KP694113 & KP694205 \\
\hline C. adspersa (Bruguière, 1789) & 5 & M.300752 & Mill Bay, Manukau Harbour & KP694144 & KP694094 & KP694190 \\
\hline C. adspersa (Bruguière, 1789) & 6 & M.321242 & Point Howard, Wellington & TBA & - & - \\
\hline C. adspersa (Bruguière, 1789) & 7 & M.315639 & Owenga, Chatham Islands & TBA & TBA & TBA \\
\hline C. alertae (Dell, 1956) & 8 & NIWA 30033 & Chatham Rise & KP694141 & KP694091 & KР694187 \\
\hline C. alertae (Dell, 1956) & 9 & NIWA 30041 & Chatham Rise & KP694142 & KP694092 & KP694188 \\
\hline C. alertae (Dell, 1956) & 10 & M.284015 & Off Chatham Islands & TBA & TBA & TBA \\
\hline C. glandiformis (Reeve, 1847) & 11 & M.317684 & Farm Cove, Hauraki Gulf & KP694152 & KР694104 & KР694199 \\
\hline C. glandiformis (Reeve, 1847) & 12 & M.317685 & Karaka Bay, Hauraki Gulf & KP694151 & KP694103 & KP694198 \\
\hline C. glandiformis (Reeve, 1847) & 13 & M.317686 & Pukenui, Aupouri Peninsula & KР694154 & KР694106 & KP694201 \\
\hline C. glandiformis (Reeve, 1847) & 14 & M.317687 & Otehei Bay, Bay of Islands & KP694155 & KP694107 & KP694202 \\
\hline C. glandiformis (Reeve, 1847) & 15 & M.317688 & Ligar Bay, Golden Bay & KP694150 & KP694102 & KP694197 \\
\hline C. glandiformis (Reeve, 1847) & 16 & M.317689 & Lower Portobello, Otago Harbour & KP694153 & KP694105 & KР694200 \\
\hline C. glandiformis (Reeve, 1847) & 17 & M.321240 & Kaiteriteri, Tasman Bay & TBA & - & - \\
\hline C. glandiformis (Reeve, 1847) & 18 & M.321241 & Pauatahanui Inlet, Wellington & TBA & - & - \\
\hline C. griseicalx Willan, 1978 & 19 & M.134974 & Great Island, Three Kings Islands & KР694129 & KР694077 & KР694173 \\
\hline C. lineolata (Lamarck, 1816) & 20 & M.309452 & Bicheno, Tasmania & KP694130 & KР694078 & KР694174 \\
\hline C. lineolata (Lamarck, 1816) & 21 & M.300769 & Pirates Bay, Tasmania & KР694133 & KP694081 & KР694177 \\
\hline C. lineolata (Lamarck, 1816) & 22 & M.317695 & Stanley, Tasmania & KP694132 & KP694080 & KP694176 \\
\hline C. lineolata (Lamarck, 1816) & 23 & M.317696 & Sulphur Creek, Tasmania & KP694131 & KР694079 & KP694175 \\
\hline C. maculosa (Martyn, 1784) & 24 & M.317699 & Milford, Hauraki Gulf & KР694140 & KР694090 & KР694186 \\
\hline C. maculosa (Martyn, 1784) & 25 & M.317718 & Kaikoura & KP694145 & KР694096 & KP694192 \\
\hline C. maculosa (Martyn, 1784) & 26 & M.317719 & Kaikoura & KP694146 & KP694097 & KP694193 \\
\hline C. maculosa (Martyn, 1784) & 27 & M.315669 & Waitangi, Chatham Islands & TBA & TBA & TBA \\
\hline C. maculosa (Martyn, 1784) & 28 & M.315642 & Owenga, Chatham Islands & TBA & TBA & TBA \\
\hline
\end{tabular}


Table 2.2. Continued...

\begin{tabular}{|c|c|c|c|c|c|c|}
\hline Species & ID & Registration & Location & $\begin{array}{l}\text { Accession \# } \\
(\mathrm{CO} 1)\end{array}$ & $\begin{array}{l}\text { Accession \# } \\
(16 S)\end{array}$ & $\begin{array}{l}\text { Accession \# } \\
(18 \mathrm{~S})\end{array}$ \\
\hline C. mirabilis canturiensis (Dell, 1951) & 29 & M.284022 & Chatham Rise & TBA & TBA & TBA \\
\hline C. mirabilis canturiensis (Dell, 1951) & 30 & M.284022 & Chatham Rise & TBA & TBA & TBA \\
\hline C. mirabilis canturiensis (Dell, 1951) & 31 & M.284016 & Off Chatham Islands & TBA & TBA & TBA \\
\hline C. nassoides (Reeve, 1846) & 32 & M.319324 & Veryan Bank, Chatham Rise & TBA & TBA & TBA \\
\hline C. nassoides (Reeve, 1846) & 33 & M.305586 & Off Auckland Islands & TBA & TBA & TBA \\
\hline C. nassoides (Reeve, 1846) & 34 & M.305586 & Off Auckland Islands & TBA & TBA & TBA \\
\hline C. nassoides (Reeve, 1846) & 35 & M.315663 & Owenga, Chatham Islands & TBA & TBA & TBA \\
\hline C. nassoides (Reeve, 1846) & 36 & M.315900 & Okawa Point, Chatham Islands & TBA & TBA & TBA \\
\hline C. nassoides (Reeve, 1846) & 37 & M.302874 & Off Kaikoura & TBA & TBA & TBA \\
\hline C. nassoides (Reeve, 1846) & 38 & M.302877 & Off Kaikoura & TBA & TBA & TBA \\
\hline C. nassoides (Reeve, 1846) & 39 & M.305641 & Off Stewart Island & TBA & TBA & TBA \\
\hline C. nassoides (Reeve, 1846) & 40 & M.305583 & Off Snares Islands & TBA & TBA & TBA \\
\hline C. nassoides (Reeve, 1846) & 41 & M.305583 & Off Snares Islands & TBA & TBA & TBA \\
\hline C. nassoides (Reeve, 1846) & 42 & M.300779 & Off Snares Islands & KP694147 & KP694098 & KP694194 \\
\hline C. nassoides (Reeve, 1846) & 43 & M.321152 & Ulva Island, Stewart Island & TBA & TBA & TBA \\
\hline C. norfolkensis (Iredale, 1940) & 44 & M.317720 & Cemetery Bay, Norfolk Island & KP694135 & KP694085 & KP694181 \\
\hline C. norfolkensis (Iredale, 1940) & 45 & M.317720 & Cemetery Bay, Norfolk Island & KP694158 & KP694111 & KP694210 \\
\hline C. quoyana A. Adams, 1855 & 46 & M.317702 & Eastern Beach, Auckland & KP694121 & KP694069 & KP694164 \\
\hline C. regalis Willan, 1978 & 47 & M.309472 & Princes Island, Three Kings Islands & KP694128 & KР694076 & KP694172 \\
\hline C. tolagaensis Ponder, 1968 & 48 & M.302859 & Tolaga Bay & KP694126 & KP694074 & KP694169 \\
\hline C. virgata H. Adams \& A. Adams, 1853 & 49 & M.100905 & Maunganui Bluff & TBA & TBA & TBA \\
\hline C. virgata H. Adams \& A. Adams, 1853 & 50 & M.317704 & Maunganui Bluff & KP694125 & KP694073 & KP694168 \\
\hline C. virgata H. Adams \& A. Adams, 1853 & 51 & M.317705 & Tapeka Point, Bay of Islands & KP694123 & KP694071 & KP694166 \\
\hline C. virgata H. Adams \& A. Adams, 1853 & 52 & M.317703 & Pukenui, Aupouri Peninsula & KP694124 & KP694072 & KP694167 \\
\hline C. virgata $\mathrm{H}$. Adams \& A. Adams, 1853 & 53 & M.317707 & Tata Beach, Golden Bay & KP694159 & KP694116 & KP694211 \\
\hline C. virgata H. Adams \& A. Adams, 1853 & 54 & M.317721 & Pohara, Nelson & KP694127 & KP694075 & KP694171 \\
\hline C. virgata $\mathrm{H}$. Adams \& A. Adams, 1853 & 55 & M.317708 & Karaka Bay, Hauraki Gulf & KP694070 & KP694165 & KP694122 \\
\hline C. virgata H. Adams \& A. Adams, 1853 & 56 & M.166286 & Paua, Parengarenga Harbour & TBA & TBA & TBA \\
\hline C. virgata H. Adams \& A. Adams, 1853 & 57 & M.166286 & Paua, Parengarenga Harbour & TBA & TBA & TBA \\
\hline C. virgata H. Adams \& A. Adams, 1853 & 58 & M.166286 & Paua, Parengarenga Harbour & TBA & TBA & TBA \\
\hline
\end{tabular}


Table 2.2. Continued...

\begin{tabular}{|c|c|c|c|c|c|c|}
\hline Species & ID & Registration & Location & $\begin{array}{l}\text { Accession \# } \\
(\mathrm{CO} 1)\end{array}$ & $\begin{array}{l}\text { Accession \# } \\
(16 \mathrm{~S})\end{array}$ & $\begin{array}{l}\text { Accession \# } \\
(18 \mathrm{~S})\end{array}$ \\
\hline C. virgata H. Adams \& A. Adams, 1853 & 59 & M.122735 & Ahipara & TBA & TBA & TBA \\
\hline C. virgata H. Adams \& A. Adams, 1853 & 60 & M.100890 & Bland Bay & TBA & TBA & TBA \\
\hline C. virgata H. Adams \& A. Adams, 1853 & 61 & M.100890 & Bland Bay & TBA & TBA & TBA \\
\hline C. virgata H. Adams \& A. Adams, 1853 & 62 & M.100890 & Bland Bay & TBA & TBA & TBA \\
\hline C. virgata H. Adams \& A. Adams, 1853 & 63 & M.105361 & McGregors Bay, Whangarei & TBA & TBA & TBA \\
\hline C. virgata H. Adams \& A. Adams, 1853 & 64 & M.105361 & McGregors Bay, Whangarei & TBA & TBA & TBA \\
\hline C. virgata H. Adams \& A. Adams, 1853 & 65 & M.105361 & McGregors Bay, Whangarei & TBA & TBA & TBA \\
\hline C. virgata H. Adams \& A. Adams, 1853 & 66 & M.105361 & McGregors Bay, Whangarei & TBA & TBA & TBA \\
\hline C. virgata H. Adams \& A. Adams, 1853 & 67 & M.092949 & Whangaumu Bay, Ngunguru & TBA & TBA & TBA \\
\hline C. virgata H. Adams \& A. Adams, 1853 & 68 & M.092949 & Whangaumu Bay, Ngunguru & TBA & TBA & TBA \\
\hline Buccinulum pertinax (Martens, 1878) & 69 & M.300791 & The Snares Islands & KP694134 & KP694084 & KP694180 \\
\hline B. vittatum (Quoy \& Gaimard, 1833) & 70 & M.317713 & Milford, Hauraki Gulf & KP694162 & KP694109 & KP694203 \\
\hline B. vittatum (Quoy \& Gaimard, 1833) & 71 & M.317712 & Warrington & KP694136 & KP694086 & KP694182 \\
\hline Pareuthria fuscata (Bruguière, 1789) & 72 & M.317715 & Northwest Bay, Campbell Island & KP694138 & KP694088 & KP694184 \\
\hline P. fuscata (Bruguière, 1789) & 73 & M.317716 & Beeman Point, Campbell Island & KP694139 & KР694089 & KP694185 \\
\hline
\end{tabular}


Table 2.3. Cominella maculosa AMOVA a priori groups and results. $\mathrm{df}=$ degrees of freedom; 'var. comp.'=variance components; '\%var.'=percentage variation; 'hapl. freq.'=measured by haplotype frequency; 'gen. diff.'= measured by pairwise genetic difference.

\begin{tabular}{|c|c|c|c|c|c|c|c|c|c|c|c|c|c|c|c|c|}
\hline & & \multicolumn{5}{|c|}{ Among groups } & \multicolumn{5}{|c|}{ Among populations within groups } & \multicolumn{5}{|c|}{ Within populations } \\
\hline \multicolumn{2}{|l|}{ A priori groups } & $\mathrm{df}$ & $\begin{array}{l}\text { var. } \\
\text { comp. }\end{array}$ & $\%$ var. & $\phi_{\mathrm{CT}}$ & p-value & df & $\begin{array}{l}\text { var. } \\
\text { comp. }\end{array}$ & $\%$ var. & $\phi_{\mathrm{SC}}$ & p-value & df & $\begin{array}{l}\text { var. } \\
\text { comp. }\end{array}$ & \%var. & $\phi_{\mathrm{ST}}$ & $\mathrm{p}$-value \\
\hline \multirow{2}{*}{$\begin{array}{l}\text { (Marokopa and } \\
\text { Hauraki Gulf to } \\
\text { Castle Pt) } \\
\text { (New Plymouth, } \\
\text { Wellington, South Is } \\
\text { and Chatham Is) }\end{array}$} & $\begin{array}{l}\text { hapl. } \\
\text { freq. }\end{array}$ & 1 & 0.2231 & 43.03 & 0.4303 & $<0.000$ & 29 & 0.1508 & 29.09 & 0.5106 & $<0.000$ & 627 & 0.1446 & 27.88 & 0.7212 & $<0.000$ \\
\hline & $\begin{array}{l}\text { gen. } \\
\text { diff. }\end{array}$ & 1 & 1.3851 & 56.34 & 0.5634 & $<0.000$ & 29 & 0.6602 & 26.85 & 0.6150 & $<0.000$ & 627 & 0.4133 & 16.81 & 0.8319 & $<0.000$ \\
\hline \multirow{2}{*}{$\begin{array}{l}\text { (Marokopa) (Hauraki } \\
\text { Gulf to Te Araroa) } \\
\text { (Tatapouri to Castle } \\
\text { Point) } \\
\text { (New Plymouth, } \\
\text { Wellington, South Is } \\
\text { except Nelson) } \\
\text { (Nelson) (Chatham } \\
\text { Is) }\end{array}$} & $\begin{array}{l}\text { hapl. } \\
\text { freq. }\end{array}$ & 5 & 0.2458 & 51.84 & 0.5184 & $<0.000$ & 25 & 0.0839 & 17.68 & 0.3671 & $<0.000$ & 627 & 0.1446 & 30.48 & 0.6952 & $<0.000$ \\
\hline & $\begin{array}{l}\text { gen. } \\
\text { diff. }\end{array}$ & 5 & 1.3244 & 62.16 & 0.6216 & $<0.000$ & 25 & 0.3930 & 18.44 & 0.4874 & $<0.000$ & 627 & 0.4133 & 19.40 & 0.8060 & $<0.000$ \\
\hline \multirow[t]{2}{*}{$\begin{array}{l}\text { (North Is) (South Is) } \\
\text { (Chatham Is) }\end{array}$} & $\begin{array}{l}\text { hapl. } \\
\text { freq. }\end{array}$ & 2 & 0.1312 & 27.10 & 0.2711 & $<0.000$ & 28 & 0.2082 & 43.02 & 0.5902 & $<0.000$ & 627 & 0.1446 & 29.87 & 0.7013 & $<0.000$ \\
\hline & $\begin{array}{l}\text { gen. } \\
\text { diff. }\end{array}$ & 2 & 0.7681 & 34.64 & 0.3464 & $<0.000$ & 28 & 1.0361 & 46.73 & 0.7149 & $<0.000$ & 627 & 0.4133 & 18.64 & 0.8137 & $<0.000$ \\
\hline
\end{tabular}


Table 2.4. Cominella virgata AMOVA a priori groups and results. $\mathrm{df}=$ degrees of freedom; 'var. comp.'=variance components; '\%var.'=percentage variation; 'hapl. freq.'=measured by haplotype frequency; 'gen. diff.'= measured by pairwise genetic difference.

\begin{tabular}{|c|c|c|c|c|c|c|c|c|c|c|c|c|c|c|c|c|}
\hline & & \multicolumn{5}{|c|}{ Among groups } & \multicolumn{5}{|c|}{ Among populations within groups } & \multicolumn{5}{|c|}{ Within populations } \\
\hline \multicolumn{2}{|l|}{ A priori groups } & $\mathrm{df}$ & $\begin{array}{l}\text { var. } \\
\text { comp. }\end{array}$ & \%var. & $\phi_{\mathrm{CT}}$ & p-value & df & $\begin{array}{l}\text { var. } \\
\text { comp. }\end{array}$ & \%var. & $\phi_{\mathrm{SC}}$ & p-value & df & $\begin{array}{l}\text { var. } \\
\text { comp. }\end{array}$ & \%var. & $\phi_{\mathrm{ST}}$ & p-value \\
\hline \multirow{2}{*}{$\begin{array}{l}\text { (Ahipara, Maunganui } \\
\text { Bluff) (Parengarenga } \\
\text { Harbour) (Bland Bay } \\
\text { to Whangarei) } \\
\text { (Hauraki Gulf and } \\
\text { South Is) (Bay of } \\
\text { Plenty to Mahia) } \\
\text { (Wellington) }\end{array}$} & $\begin{array}{l}\text { hapl. } \\
\text { freq. }\end{array}$ & 5 & 0.2207 & 46.89 & 0.4689 & $<0.000$ & 16 & 0.0933 & 19.82 & 0.3731 & $<0.000$ & 475 & 0.1567 & 33.29 & 0.6671 & $<0.000$ \\
\hline & $\begin{array}{l}\text { gen. } \\
\text { diff. }\end{array}$ & 5 & 1.3758 & 52.60 & 0.5260 & $<0.000$ & 16 & 0.3950 & 15.10 & 0.3186 & $<0.000$ & 475 & 0.8449 & 32.30 & 0.6770 & $<0.000$ \\
\hline \multirow{2}{*}{$\begin{array}{l}\text { (Ahipara, Maunganui } \\
\text { Bluff) (Parengarenga } \\
\text { Harbour) (Bland Bay } \\
\text { to Whangarei) } \\
\text { (Hauraki Gulf) (Bay } \\
\text { of Plenty to Mahia) } \\
\text { (Wellington) (South } \\
\text { Is) }\end{array}$} & $\begin{array}{l}\text { hapl. } \\
\text { freq. }\end{array}$ & 6 & 0.1964 & 43.59 & 0.4359 & $<0.000$ & 15 & 0.0975 & 21.63 & 0.3834 & $<0.000$ & 475 & 0.1567 & 34.78 & 0.6522 & $<0.000$ \\
\hline & $\begin{array}{l}\text { gen. } \\
\text { diff. }\end{array}$ & 6 & 1.2414 & 49.80 & 0.4980 & $<0.000$ & 15 & 0.4062 & 16.30 & 0.3247 & $<0.000$ & 475 & 0.8449 & 33.90 & 0.6610 & $<0.000$ \\
\hline \multirow{2}{*}{$\begin{array}{l}\text { (north of Wellington) } \\
\text { (Wellington and } \\
\text { South Is) }\end{array}$} & $\begin{array}{l}\text { hapl. } \\
\text { freq. }\end{array}$ & 1 & 0.0376 & 8.52 & 0.0852 & 0.050 & 20 & 0.2476 & 56.03 & 0.6124 & $<0.000$ & 475 & 0.1567 & 35.46 & 0.6454 & $<0.000$ \\
\hline & $\begin{array}{l}\text { gen. } \\
\text { diff. }\end{array}$ & 1 & 0.1694 & 7.05 & 0.0706 & 0.082 & 20 & 1.3871 & 57.76 & 0.6215 & $<0.000$ & 475 & 0.8449 & 35.18 & 0.6482 & $<0.000$ \\
\hline
\end{tabular}




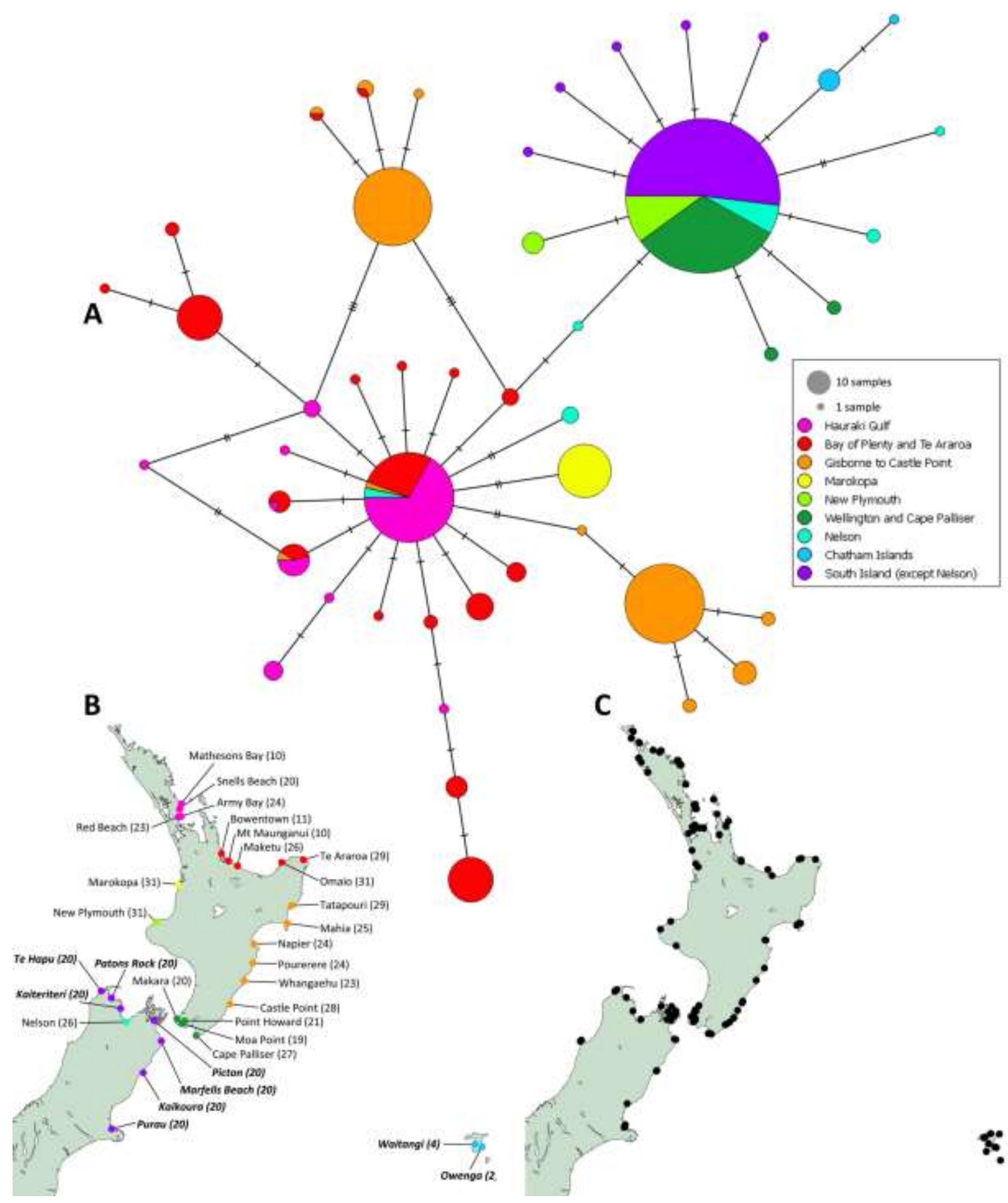

Figure 2.1. A) CO1 median joining haplotype network for Cominella maculosa. Hatch-marks represent one mutational step. B) Sample sizes (numbers) and sites (coloured circles). Colours correspond to the haplotype network regions (see key). Bold and italicized location names correspond to sites originating from this study. Others comprise the dataset of Fleming et al. (in review). C) Distribution records of C. maculosa held at NMNZ. 


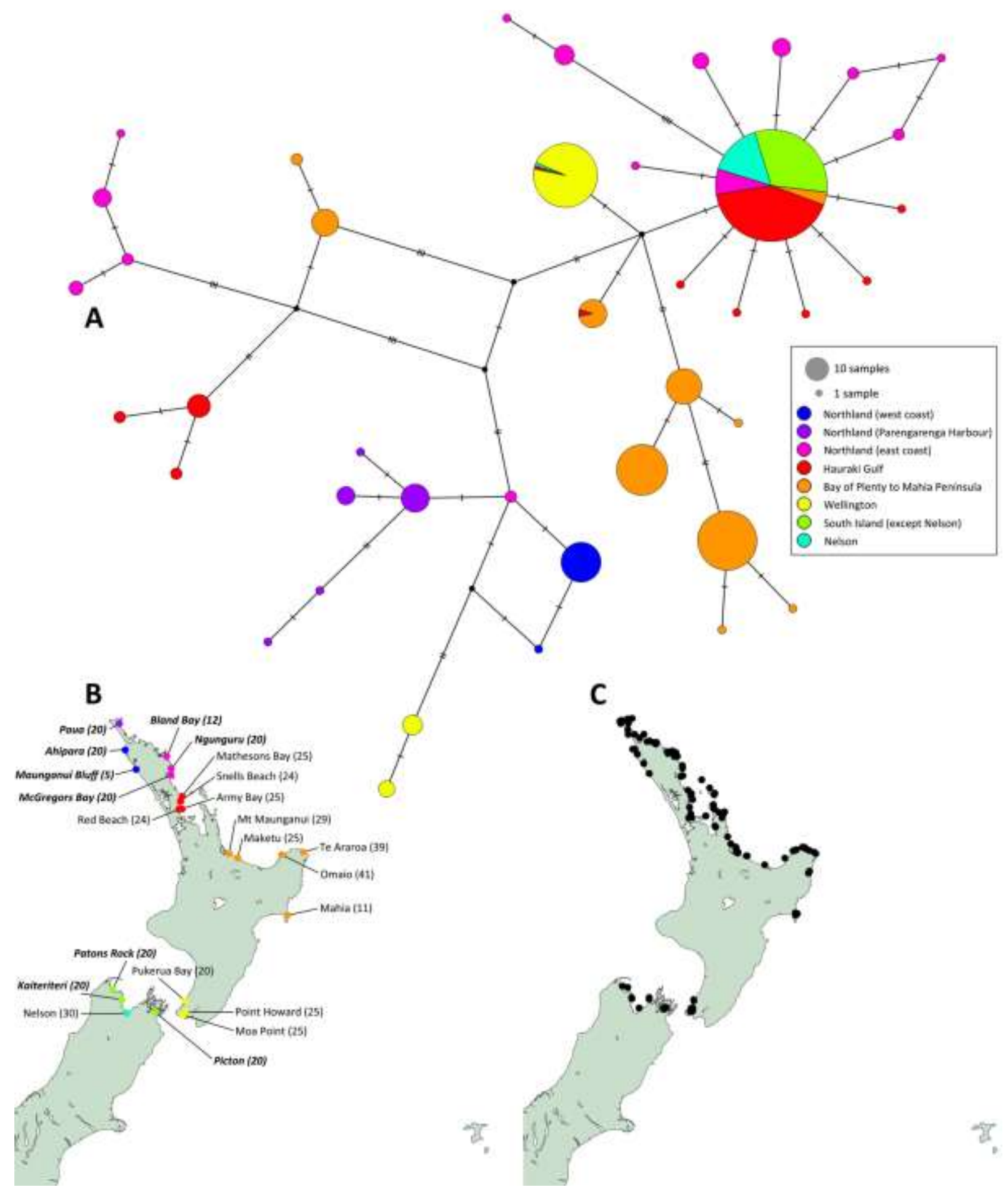

Figure 2.2. A) CO1 median joining haplotype network for Cominella virgata. Hatch-marks represent one mutational step. B) Sample sizes (numbers) and sites (coloured circles). Colours correspond to the haplotype network regions (see key). Bold and italicized location names correspond to sites originating from this study. Others comprise the dataset of Fleming et al. (in review). C) Distribution records of $C$. virgata held at NMNZ. Note the disjunct population centres. 
A

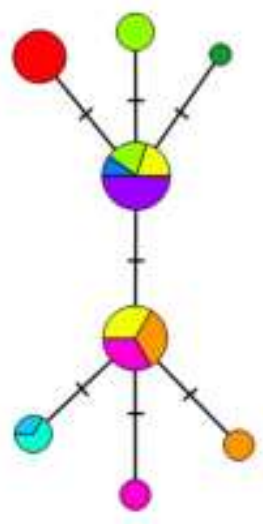

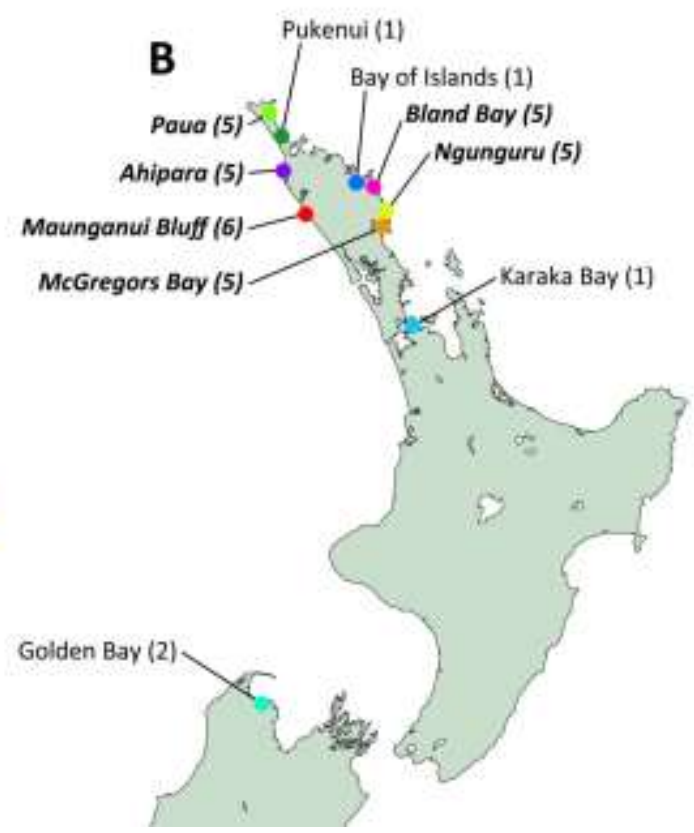

Figure 2.3. A) $16 \mathrm{~S}$ median joining haplotype network for Cominella virgata. Hatch-marks represent one mutational step. B) Sample sizes (numbers) and sites (coloured circles). Colours correspond to the haplotype network regions (see key). Bold and italicized location names correspond to sites originating from this study. Others originated from Donald et al. (2015) via GenBank
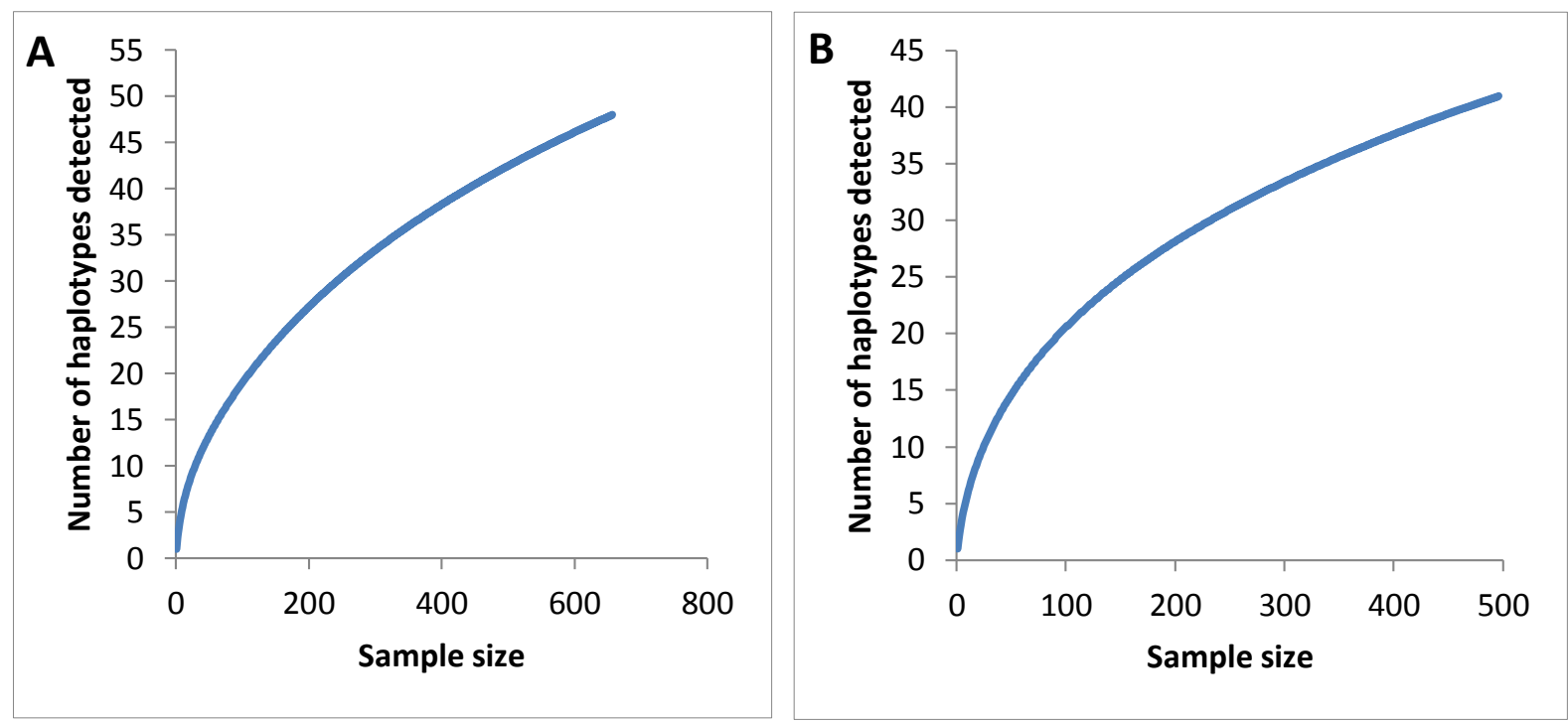

Figure 2.4. Rarefaction curves for $\mathrm{CO} 1$ haplotypes of A) Cominella maculosa. B) C. virgata. 


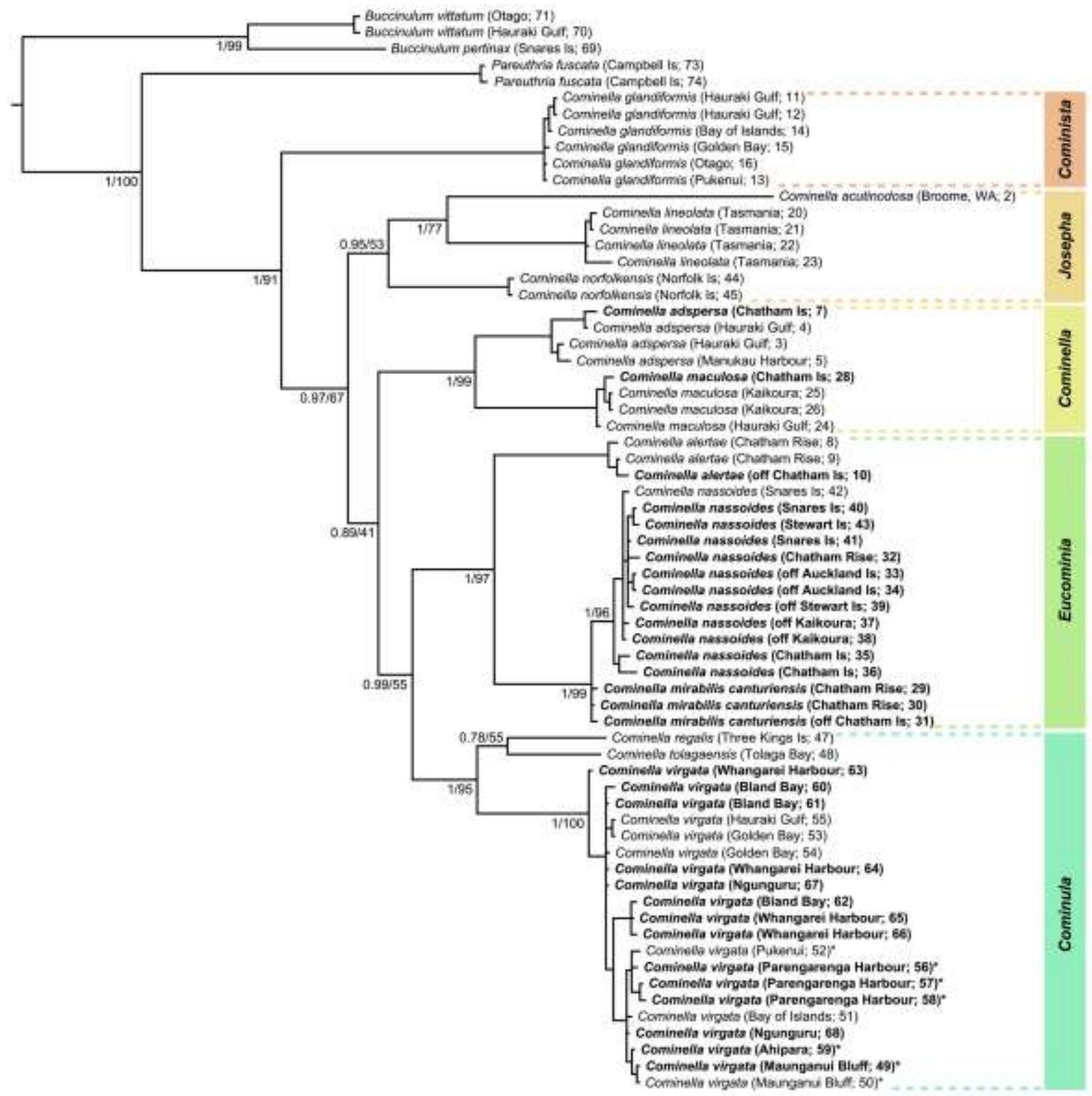

Figure 2.5. Bayesian phylogenetic tree of concatenated CO1 (528 bp), 16S (457 bp) and 18S (711 bp) gene sequences totalling 1,696 bp. Node labels correspond to Bayesian posterior probabilities (left) and maximum likelihood (ML) consensus bootstrap support percentage (right), the latter from a ML tree with very similar topologies (see appendix). Bold and italicized sequence labels correspond to sequences originating from this study. Others originated from Donald et al. (2015) via GenBank (Table 2.2). '*' denotes specimens of C. virgata of the 'brookesi' shell form. 


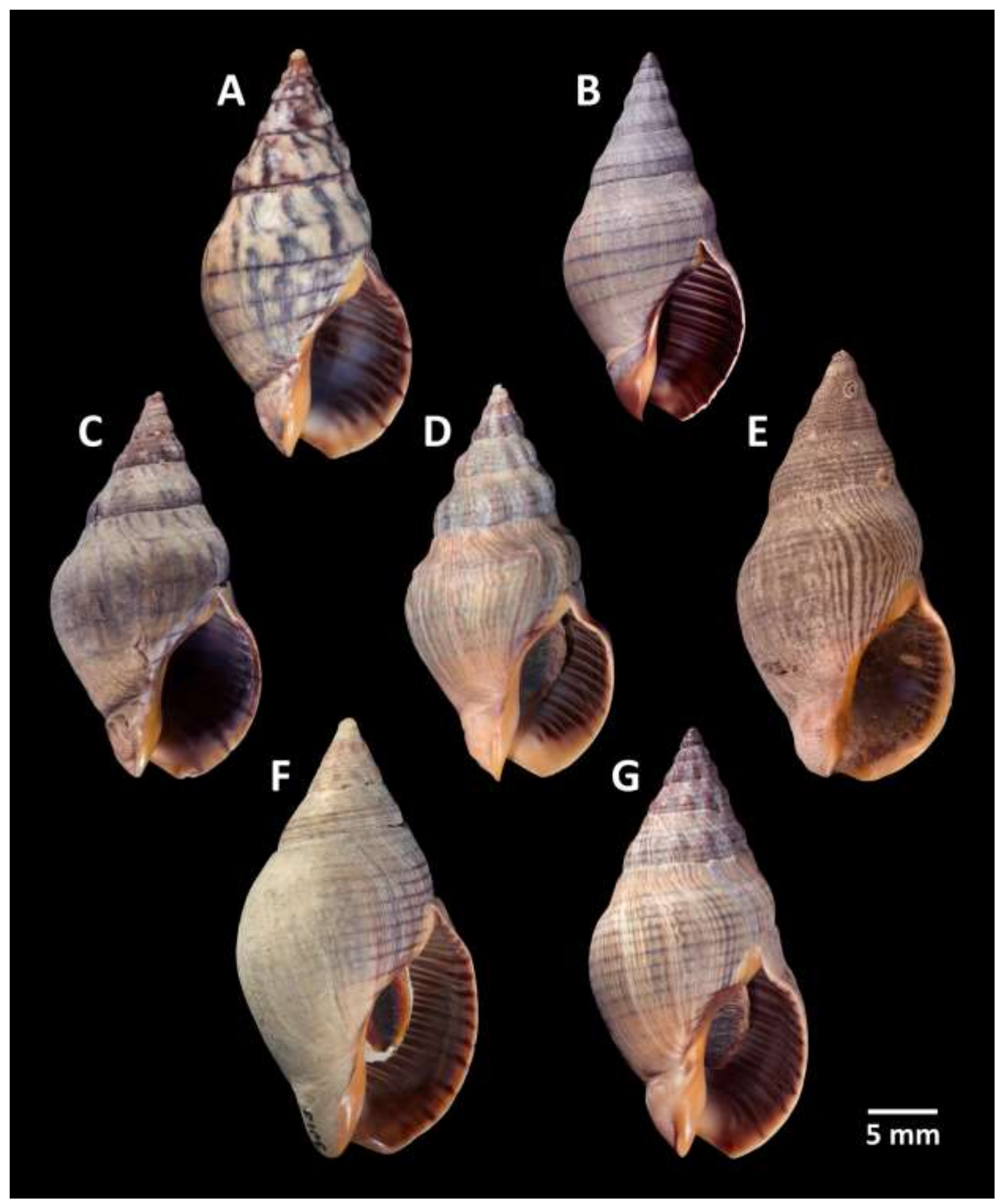

Figure 2.6. Type specimens and variations of $C$. virgata to scale. A) Pink Beach, Leigh, M.090919. B) Waihau Bay, Raukumara Peninsula, M.321237. C) Bay of Islands, lectotype (here designated) of both Buccinum lineolatum Quoy \& Gaimard, 1833 and C. virgata H. Adams \& A. Adams, 1853, MNHN-IM-2000-6968. D) Te Hapua, Parengarenga Harbour, M.278721. E) Whatuwhiwhi, Karikari Peninsula, holotype of C. virgata brookesi Powell, 1952, AM 71191. F) The Bluff, Ninety Mile Beach, M.278743. G) Reef Point, Ahipara, M.278752. 


\section{Discussion}

Distribution of Cominella virgata

The distribution of $C$. virgata features two separate population centres, one situated in the Cook Strait region, and the other in the northern and northeastern North Island (Fig. 2.2C). Beu (2012) noted similar distribution patterns for other mollusc taxa, including Murexul octogonus (Quoy \& Gaimard, 1833) and Roseaplagis rufozona (A. Adams, 1853) (Marshall 1998), but what Beu (2012: 4) considered a "minor" pattern proves to be quite common throughout the Gastropoda and Bivalvia (B.A.M. pers. obs.). The causes of these northeastern/south-western disjunctions remain to be established. While the ages of the disjunctions are also unclear, most or all are likely to predate the LGM as some of these taxa (including M. octogonus and R. rufozona) have fossil records in the Whanganui coastal sequence (Fleming 1953).

The present distribution gap between the two population centres for $C$. virgata on the west coast falls between Maunganui Bluff and Paekākāriki. This region includes seemingly favourable habitats interspersed between large tracts of unfavourable sandy beach habitat. On the east coast the distribution gap falls between Mahia Peninsula and Pencarrow Head. There is a long stretch of unfavourable sandy beach habitat to the west of Mahia in Hawkes Bay, followed by a long stretch of seemingly favourable habitats to the south between Napier and Pencarrow Head. The eastern and western gaps both seem unlikely to be sampling artefacts because extensive searches in seemingly suitable habitat yielded no C. virgata between Napier and Palliser Bay or near Hawera, New Plymouth, Raglan and Port Waikato (all localities where $C$. maculosa occurs). The species was notably omitted from published records of the west coast fauna of the central North Island (Morley et al. 1997; Hayward et al. 1999; Hayward et al. 2002), except for a 'dubious' record from off $\mathrm{Ngā}$ Motu in New Plymouth (Hayward and Morley 2002: 3). 
Low CO1 diversity and a lack of private haplotypes in South Island populations of $C$. virgata suggest recent population size and/or range expansion. One of the two haplotypes present falls into a haplogroup primarily affiliated with Wellington, and is represented by a single sequence from Nelson (Fig. 2.2A), of indeterminate origin, but probably stemming from a translocated lineage. The most common South Island haplotype, comprising 89 of the 90 sequences, is shared with populations from the north-eastern North Island, but has not been sampled in geographically intermediate populations on the north-western North Island, at Mahia or around Wellington (Table 2.1; Fig. 2.2A). This haplotype forms the centre-point of a recently diversified ('star-shaped') haplogroup that features several haplotypes which are one mutational step divergent from the centre-point. All of these haplotypes are from the north-eastern North Island, suggesting that this haplogroup has had a longer presence in- and probably originated from- the north-eastern North Island. The South Island populations of $C$. virgata are therefore likely to have originated through unintentional human-mediated translocations, probably from both the north-eastern North Island as well as Wellington, accounting for both haplotypes present. Similarly, it is likely that populations of the fasciolariid Taron dubius (Hutton, 1878) in the northern South Island were also introduced from the north-eastern North Island, where it normally occurs.

By the mid 1960's, populations of C. virgata were established in the Marlborough Sounds (M.278694), Tasman Bay (M.023105) and Golden Bay (M.278701), encompassing much of their current range in the South Island. A lack of earlier records may reflect sampling effort. The timing of the proposed translocation events and the subsequent rate of range expansion in the South Island are unknown. The reason for failure to spread further south, where there is seemingly suitable habitat, remains to be established, but it may simply be a matter of time. 
It is unclear from the presently available data if Wellington populations of $C$. virgata are naturally occurring or if these also originated from humanmediated translocations from the north-eastern North Island. The earliest records date from 1953 (M.005888), neither supporting nor contradicting either contention. However, had the Wellington populations originated through translocation events, several rare haplotypes otherwise undetected by the present sampling must have been translocated and become fixed due to genetic drift and/or founder effects. Three haplotypes are present in Wellington. Two of these form a private haplogroup. The third clusters on its own and occurs at the highest frequency of the three. In addition to sequences from Wellington, this third haplotype is represented by one sequence from the Hauraki Gulf and another from Nelson (Fig. 2.2A). Both of these sequences are potentially from translocated lineages as all three locations constitute major ports, in which case all three Wellington haplotypes might then be considered private. The presence of multiple private haplotypes supports the suggestion that Wellington populations are naturally-occurring.

\section{Cook Strait populations of Cominella maculosa}

C. maculosa and C. virgata have very different patterns of genetic structure in the Cook Strait region. C. maculosa has nine private South Island haplotypes and shares a high-frequency haplotype with populations from the southern North Island (Fig. 2.1A). A second haplotype is shared between the North and South islands. In the South Island, this haplotype only occurs in Nelson, and together with a haplotype that is private to Nelson (both represented by three out of the 26 sequences), it falls into a haplogroup otherwise unique to the northern North Island (Fig. 2.1A). All other haplotypes present in populations from and to the south of New Plymouth on the west coast and Cape Palliser on the east coast form a single 'southern' haplogroup.

'Southern' populations have far less diversity than populations from further north (Fig. 2.1A), potentially resulting from smaller population sizes, shorter regional occupancy times or a combination of the two. Lower diversity in southern regions may reflect southward range expansion by isotherm tracking 
following the LGM (Fraser et al. 2012), which would be characterised by both population size expansion and founder events (Fraser et al. 2012; Waters et al. 2013) leading to low diversity. When a population became established at a site, the success of additional dispersers from other regions could have been limited by high-density blocking effects (Waters 2011; Waters et al. 2013). Combined with the poor dispersal ability of C. maculosa, blocking effects could maintain low levels of genetic diversity in southern populations. Isotherm tracking has been reported for several New Zealand molluscs, including C. nassoides (Reeve, 1846) (Walton and Marshall in prep.), the scallop Zygochlamys delicatula (Hutton, 1873) (Beu 1969; Beu and Maxwell 1990; Beu 1999), and the trochoid gastropod Maurea blacki (Powell, 1950) (Marshall 1995).

Phylogeographic breaks have been identified in the Cook Strait region for a range of taxa, although break locations are poorly constrained and may vary considerably between species (Ross et al. 2009; Gardner et al. 2010). Few species have a North Island/South Island break like $C$. virgata. More commonly, the 'northern group' includes populations from the northern South Island (Apte and Gardner 2002; Apte et al. 2003; Star et al. 2003; Waters and Roy 2004; Ayers and Waters 2005; Goldstien et al. 2006; Veale and Lavery 2011; Wei et al. 2013a, b). Some breaks have been recorded or implied near or to the south of Te Hapu (Waters and Roy 2004; Ayers and Waters 2005; Wei et al. 2013a, b), which is the southernmost site sampled for C. maculosa (Table 2.1). However, there are no apparent geographic features to the south of Te Hapu that are likely to cause a phylogeographic disjunction in $C$. maculosa and it seems unlikely that such a break exists if the low genetic diversity in southern populations is due to recent southern population size and range expansion.

Refugia during glacial maxima were probably located well to the north of Wellington as water temperatures are likely to have been too low for $C$. maculosa or C. virgata. Different refugia populations could have founded the various southern lineages in Wellington and the South Island of C. virgata. In C. maculosa, the phylogeographic break between Marokopa and New 
Plymouth (Fleming et al. in prep.; Fig. 2.1A) and relative homogeneity of populations to the south, suggests a possible refugium in the vicinity of New Plymouth. The causes of a phylogeographic break in $C$. maculosa between Castle Point and Cape Palliser (Fleming et al. in prep.; Fig. 2.1A) are unclear but it seems unlikely that they reflect prevailing conditions in Cook Strait. This break may be due to the confluence of two lineages spreading southwards along the west and east coasts during the period of warming following the LGM. The patterns of a phylogenetic break that can be detected using mtDNA can take considerable time to disestablish through admixture, so the historic causes of a break might not reflect contemporary geography or ocean conditions.

As eustatic sea-levels rose subsequent to the LGM, the coastline along the south-western North Island would have advanced tens of kilometres inland from the near the edge of the continental shelf to its present location. The rate of introgression is unclear. Without continuous suitable habitat during this transition and on a relatively fine geographic scale, many populations of rocky-shore species with poor dispersal ability may have become isolated or extirpated during this period.

As with C. maculosa and C. virgata, amphipod species of the genus Paracorophium Stebbing, 1899 (Stevens and Hogg 2004; Knox et al. 2011), and some limpets of the genus Cellana H. Adams, 1869 (Goldstien 2005; Goldstien et al. 2006), congeners with similar life history strategies can exhibit differing patterns of genetic structure. Phylogeographic breaks in the Cook Strait region are likely to have several and differing causes. These may include aspects of the complex and dynamic local geography and ocean circulation patterns, and differences in larval duration and behaviour in the water column. The Cook Strait region extends far to the west of the Narrows, which are often incorrectly treated as the entirety of Cook Strait (Lewis et al. 1994). To loosely term 'the Cook Strait break' is, thus, misleading (Goldstien et al. 2006; Ross et al. 2009). Without multiple studies of different taxa and markers, deducing historical causes from patterns in genetic structure remains conjecture at best. 


\section{Northern populations of Cominella virgata}

Throughout its distribution, the shell of $C$. virgata has a sculpture of commarginal axial costae, strongest at the edge of the subsutural concavity, and becoming evanescent near the abapical third of the base and often obsolete on later teleoconch whorls. Unusually, $C$. virgata inhabits mudflats in Parengarenga and Houhora Harbours. Specimens from these localities have larger and more persistent axial costae and a broader shoulder slope (Fig. 2.7D) than specimens from adjacent open coasts and the rest of New Zealand, perhaps local adaptations to reduce sinking in mud (Thayer 1975).

Specimens from and north of Maunganui Bluff on the west coast, and north of the Bay of Islands on the east coast (Fig. 2.7D-G), generally have more numerous (>8) and crowded spiral chords, as well as a colour pattern of crowded, narrow, flexuous, axial flammules, rather than the broad and highly irregular lines or blotches characteristic of southern populations (Fig. 2.7AC). Powell (1952) distinguished C. virgata brookesi Powell, 1952 (type locality: Whatuwhiwhi, Karikari Peninsula) on this basis, listing Te Hapua, Whangaroa Harbour and Aurere as other localities, either ignoring or unaware of yet more divergent forms on the west coast of Northland (Fig. 2.7F, G).

Apart from the presence of narrow axial colour bands, the holotype of $C$. virgata brookesi (Fig. 2.7E) is indistinguishable from C. virgata virgata (type locality: the Bay of Islands), from and south of the Bay of Islands. Morley et al. (2006: 17) identified C. virgata from Mahia Peninsula as being "f. [forma] brookesi" although all specimens from Mahia Peninsula at NMNZ are the nominal form.

The phylogenies reported by Donald et al. (2015) showed two clades within $C$. virgata. Donald et al. (2015) interpreted the northern clade, comprised of specimens from Pukenui (c.25 km from Whatuwhiwhi), Maunganui Bluff, the Bay of Islands and Taupiri Bay, as conforming to the subspecies C. virgata brookesi. The southern clade was comprised of specimens from Waitemata Harbour and Golden Bay and was treated as C. virgata virgata (Donald et al. 
2015). The shell voucher specimens from the Bay of Islands (M.317705) and Taupiri Bay (M.317706), although damaged during soft-tissue extraction, are typical C. virgata virgata. That from the Bay of Islands is arguably a topotype, although "the Bay of Islands" is a broad locality descriptor.

The expanded phylogeny (Fig. 2.6) did recover the same two clades within $C$. virgata reported by Donald et al. (2015) however these were obscured by numerous additional clades. None appear to warrant any formal taxonomic distinction. Neither the Northland forms nor typical $C$. virgata formed monophyletic clades (Fig. 2.7).

Considering the CO1 data (Fig. 2.2), DNA sequences from populations on the western and northern coasts of Northland clustered together and had numerous private haplotypes, but did not fall into significantly distinct haplogroups relative to other haplotypes and regions. In addition, the various shell forms of C. virgata from throughout its distribution, including the holotype of $C$. virgata brookesi and lectotype of $C$. virgata virgata (see below), fluidly intergrade, thus, continued recognition of separate subspecies is unjustified. As interpreted here, the brookesi form describes specimens with more than eight spiral threads and crowded narrow axial flammules. It is known only from north of the Bay of Islands but typical shell forms and intermediates occur sympatrically throughout much of this distribution although in low relative abundance.

Taxonomic remarks on Cominella virgata.

\section{Cominella (Cominula) virgata H. Adams \& A. Adams, 1853}

Fig. 2.7A-H.

Buccinum lineolatum Quoy \& Gaimard, 1833: 419; pl. 30, figs. 14-16. Not B. lineolatum Lamarck, 1816 (homonym).

Cominella virgata H. Adams \& A. Adams, 1853: 110; pl. 11, fig. 6 (not 6a, b). Undeclared replacement name for B. lineolatum Quoy \& Gaimard, 1833.

Cominella virgata brookesi Powell, 1952: 181, p. 35, fig. 7. New synonymy. 
Type material:

Buccinum lineolatum (Quoy \& Gaimard; not Lamarck) and Cominella virgata: lectotype (here selected) MNHN IM-2000-6968 and paralectotypes (3, MNHN), Bay of Islands, New Zealand.

Cominella virgata brookesi: holotype AM 71191, Whatuwhiwhi, Rangiawhia (Karikari) Peninsula, Mangonui County, D. Forsyth.

Quoy and Gaimard (1833) introduced Buccinum lineolatum for specimens from the Bay of Islands, their illustrations and description matching the New Zealand species $C$. virgata. All four syntypes (MNHN) are typical C. virgata, one of which (Fig. 2.7C) is here designated the lectotype to ensure proper and consistent future usage. Quoy and Gaimard's name is invalid due to homonymy with the prior $B$. lineolatum of Lamarck (1816), a common Cominella species from southern Australia (Wilson 1994; probable syntypes at MHNG, Chapter 1).

H. Adams and A. Adams (1853) introduced C. virgata in conjunction with a list of Cominella species "virgata, H. and A. Adams (lineolata, Quoy and Gaim.)", referring to an illustration that is clearly a reproduction of one of Quoy and Gaimard's (1833, pl. 30, fig. 15) original colour illustrations of the New Zealand species. Although not specifically stated, C. virgata was evidently intended as a replacement name for Quoy and Gaimard's (1833) and so shares the same type material. No specimens were included in the $\mathrm{H}$. and A. Adams collection now at NHMUK (A. Salvador pers. comm. 2017).

\section{Acknowledgements}

We are grateful to many people who contributed towards this manuscript, notably: Jean-Claude Stahl (NMNZ) for imaging of specimens; Bruce Hayward (Geomarine Sciences) for comments on Auckland Isthmus geography; Wilma Blom and Severine Hannam (AM) for images of the 
holotype of Cominella virgata brookesi; Virginie Héros (MNHN), Emmanuel Tardy (MHNG) and Andreia Salvador (NHMUK) for comments on and assistance locating type material; Cécile Massiot (GNS) for translations of French texts, Melanie Dohner and Angela Fleming (VUW) for assistance with lab techniques and making available their data, and Sebastian Logan (VUW) for sequences of $C$. adspersa and $C$. glandiformis; Simon Grove (TMAG) for comments on $C$. lineolata; Meredith Buchholz for her support and for assistance with sample collection, together with Kevin Burch (Whangarei), Kathy Carson (Christchurch), Peter Cresswell (Motueka), Derrick Crosby (Whakatane), Kevin and Yvonne Mead (French Pass), Jason Plaisted (Wellington), Marc Sykes (Wellington) and Mike Young (Motueka). The image of the lectotype of Buccinum lineolatum Quoy \& Gaimard, 1833 was taken by M. Cabeller (MNHN) as part of project E-RECOLNAT (ANR-11INBS-0004).

\section{Author contributions}

$\mathrm{KW}$ organised and participated in the collection of specimens, completed all lab-work, analyses, and wrote the manuscript. BAM assisted with specimen curation and taxonomic convention as well as providing comments on the interpretation and manuscript. NEP and PAR provided the Fleming et al. (in review) dataset and commented on the manuscript and project design. AJFV assisted with computer programs and statistics. 


\section{Chapter 3: General conclusion and closing remarks}

\section{Research questions overview}

Whilst South Island populations of Cominella maculosa are undoubtedly naturally occurring, it seems highly likely that those of $C$. virgata were founded by human-mediated translocation events from the north-eastern North Island. It is unclear if populations of $C$. virgata from Wellington are naturally occurring. Haplotypes are present in Wellington that are rare or absent in other regions. However, $C$. virgata has a curious distribution disjunction and does not occur for hundreds of kilometres along either the western or eastern coasts of the North Island immediately to the north of Wellington.

In C. maculosa phylogeographic breaks are reported in the North Island between Marokopa and New Plymouth on the west coast and between Castle Point and Cape Palliser on the east coast. The causes of either of these breaks remain to be established. It seems unlikely that they reflect prevailing conditions in the Cook Strait or that they have much to do with the Cook Strait at all. The west coast break may be due to a refugium during the LGM at or to the north of New Plymouth. The east coast break may result from the confluence of two lineages range-expanding southwards down the western and eastern coasts of the North Island. Populations between these breaks to the south form a single 'southern' haplogroup with relatively low diversity.

The South Island populations of $C$. maculosa sampled in this study differ from the Nelson population sampled by Fleming et al. (in review) in having fewer haplotypes and less haplotype diversity. The only South Island samples to include haplotypes not of the 'southern' haplogroup for C. maculosa were from Nelson. In contrast, all South Island sites for $C$. virgata have the same fixed haplotype with the exception of one individual sampled from Nelson by Fleming et al. (in review) that had a haplotype that is most common in Wellington. This individual may be from a translocated lineage. 
Chatham Islands samples of C. maculosa had two haplotypes that formed a separate sub-group to the 'southern' haplogroup. This result suggests that Chatham Islands populations are moderately isolated from those on the mainland but may have been founded from 'southern' populations relatively recently.

The purported northern subspecies $C$. virgata brookesi does not form a monophyletic lineage and is synonymised with $C$. virgata. Northland populations of $C$. virgata have very high $\mathrm{CO} 1$ diversity, paralleling their high morphological diversity, but forms are not so divergent as to warrant taxonomic recognition. Few haplotypes are shared between northern populations and additional sample sites would be needed to establish the geographic scale of haplotype transitions in this region. When high northern diversity is contrasted with the low diversity in southern populations of $C$. maculosa using the same methods and DNA marker, this illustrates the effect of occupancy time and/or population size on genetic diversity.

\section{Future research}

The results presented in this study have highlighted several potential directions for further research. Validity of the various proposed subspecies of $C$. nassoides (Reeve, 1846) is currently being reviewed by Walton and Marshall (in prep.) and the phylogeny presented here (Chapter 2) suggests relatively little genetic difference between individuals from widely separate localities. Low levels of regional structuring are also observed for $C$. glandiformis (Reeve, 1847) (Chapter 2, Fig. 2.5). Observations of its larval development under differing conditions would be valuable to help establish whether or not it has lecithotrophic larvae.

The patterns of phylogeographic structure detected in the present study are concordant with those of other littoral marine species studied that have direct 
development (Kojima et al. 2004; Keeney et al. 2009; Keeney et al. 2013; Sánchez et al. 2013). Only a few species with direct development have been the subject of phylogeographic study in New Zealand (Keeney et al. 2009; Keeney et al. 2013; Dohner 2016; Fleming et al. in prep.) and C. adspersa (Bruguière, 1789) and species of Haustrum Perry, 1811 would be suitable candidates for building a more comprehensive picture of the general population genetic patterns. Littoral marine species are often predisposed to inadvertent human-mediated translocation. The genetic evidence for recent human-mediated translocation can be difficult to interpret and in some cases it could appear as just a complicated piece of the phylogeographic pattern.

The possible causes and ages of the 'north-eastern/south-western' pattern of distribution disjunctions presented in Chapter 2 for various mollusc taxa are worthy of future examination. The present molecular results do not provide much insight as to how this pattern may have arisen for $C$. virgata, but the causes may differ between species. Moreover, the susceptibility of $C$. virgata to translocation convolutes the interpretation of molecular results. Sub-littoral species such as M. octogonus (Quoy \& Gaimard, 1833) and R. rufozona (A. Adams, 1853) are less likely to come into contact with potential rafting material or be translocated as bio-foul attached to hulls or within ballast. Accordingly, these species would be well suited to investigate these questions. In addition, both $M$. octogonus and $R$. rufozona occupy a range of habitat types and may accordingly be less susceptible to extirpation with changing coastlines during the transitions between glacial cycles.

The influence of changing water temperatures during glacial cycles on the formation and maintenance of these distribution patterns and disjunctions remains to be established. It is unclear if some or all species that have a similar disjunct distribution pattern once had continuous populations along the western and/or eastern coasts of the North Island. An interesting consideration is the presence of a marine strait bisecting the Auckland Isthmus in times of higher eustatic sea-levels during some glacial minima. A marine corridor between the west and east coasts would have allowed for the dispersal of some marine species and this corridor could have had a strong influence on 
distribution patterns. Beu (2004: 119) implies the most recent occurrence of a strait through the Auckland Isthmus may have been during the previous interglacial in the Late Pleistocene, by suggesting that the strait was closed by an eruption in the Portage Volcano Complex c. $25 \mathrm{ka}$ BP (Sandiford et al. 2002; Beu 2004). This eruption would have coincided with the onset of the LGM (Sandiford et al. 2002) when eustatic sea-levels would have begun to lower considerably.

A Late Pleistocene strait in Auckland would have been located near Otahuhu, the narrowest point of the Auckland Isthmus at less than two kilometres wide, and/or along the "Clevedon Strait", c.14 km to the south. Both locations currently have as little as $30 \mathrm{~m}$ of elevation separating the western and eastern coasts. The vicinity of the Auckland Isthmus has been subject to considerable uplift post-Miocene (Claessens et al. 2009; Kenny et al. 2012) but seemingly little in the past $1 \mathrm{Ma}$ (Alloway et al. 2004; Marra et al. 2006). The timing, location and rate of uplift and/or subsidence in the immediate vicinity of possible straits is unclear, therefore, it is likewise unclear during which glacial minima straits were present (B.W. Hayward pers. comm. 2016).

Straits through the Auckland Isthmus are likely to have been present during the Pliocene, when eustatic sea-levels were up to $30 \mathrm{~m}$ higher than present (Dwyer and Chandler 2009; Naish and Wilson 2009). There may have also been a strait present during the Early Pleistocene (B.W. Hayward pers. comm. 2016), however, there is little or no evidence for the presence of a strait within the past $1 \mathrm{Ma}$ (B.W. Hayward pers. comm. 2016), when eustatic sea-levels during glacial minima were, at most, $10 \mathrm{~m}$ higher (Naish and Wilson 2009). The approximately three hours and $1.5 \mathrm{~m}$ tidal difference between the western and eastern coasts of Auckland would have led to very strong currents passing through any strait and scoured a large channel. Had there been a strait through the Auckland Isthmus within the past $1 \mathrm{Ma}$, it is expected that there would have been considerable amounts of erosion through the Kidnappers and Waitemata group basement formations; much more so than has been observed (B.W. Hayward pers. comm. 2016). 
There is little or no evidence for Pleistocene gene-flow across the Auckland Isthmus from marine species. Conversely, there is some evidence of long-term isolation between populations on either side of the Auckland Isthmus in many species, such as the anemone Actinia tenebrosa Farquhar, 1898 (Veale and Lavery 2012) and cockle Austrovenus stutchburyi (Ross et al. 2012). While the relationships between populations of amphipods in genus Paracorophium (Stevens and Hogg 2004; Knox et al. 2011) could result from some historic dispersal through the Auckland Isthmus via a strait, it has been suggested that estuarine amphipods may also be translocated by wading birds (Schnabel et al. 2000).

Accurately dating or inferring directionality of gene-flow requires a large dataset. A future DNA-based approach comprising multiple species and higher resolution genome-wide markers could potentially help to establish the presence and constrain the timing of marine straits through the Auckland Isthmus during the Pliocene and Pleistocene.

Continued contributions improving our depth of knowledge about New Zealand's coastal marine fauna will hopefully make our understanding of reality a little less 'frequently inaccurate'.

\section{References}

Adams, H. \& Adams, A (1853-1854) The genera of recent Mollusca. 1. Van Voorst, London.

Alloway, B.V., Westgate, J., Pillans, B., Pearce, N., Newnham, R.M., Byrami, M. \& Aarburg, S. (2004) Stratigraphy, age and correlation of middle Pleistocene silicic tephras in the Auckland region, New Zealand: a prolific distal record of Taupo Volcanic Zone volcanism. New Zealand Journal of Geology and Geophysics, 47(3), 447-479. 
Ansell, A.D. (2000) Drilling and non-drilling predation in gastropod aggregations in the intertidal zone of a New Zealand harbour. Journal of Molluscan Studies, $66,419-422$.

Apte, S. \& Gardner, J.P.A. (2001) Absence of population genetic differentiation in the New Zealand greenshell mussel Perna canaliculus (Gmelin 1791) as assessed by allozyme variation. Journal of Experimental Marine Biology and Ecology, 258(2), 173-194.

Apte, S. \& Gardner, J.P.A. (2002) Population genetic subdivision in the New Zealand greenshell mussel (Perna canaliculus) inferred from single-strand conformation polymorphism analysis of mitochondrial DNA. Molecular Ecology, 11(9), 1617-1628.

Apte, S., Star, B. \& Gardner, J.P.A. (2003) A comparison of genetic diversity between cultured and wild populations, and a test for genetic introgression in the New Zealand greenshell mussel Perna canaliculus (Gmelin 1791). Aquaculture, 219(1), 193-220.

Arrieta, J.M., Arnaud-Haond, S. \& Duarte, C.M. (2010) What lies underneath: conserving the oceans' genetic resources. Proceedings of the National Academy of Sciences of the United States of America, 107(43), 18318-18324.

Avise, J.C. (1992) Molecular population structure and the biogeographic history of a regional fauna: a case history with lessons for conservation biology. Oikos, 63(1), 62-76.

Avise, J.C. (2000) Phylogeography: the history and formation of species. Harvard University Press, Cambridge, Massachusetts.

Avise, J.C., Arnold, J., Ball, R.M., Bermingham, E., Lamb, T., Neigel, J.E., Reeb, C.A. \& Saunders, N.C. (1987) Intraspecific phylogeography: the mitochondrial DNA bridge between population genetics and systematics. Annual Review of Ecology and Systematics, 18, 489-522. 
Ayers, K.L. \& Waters, J.M. (2005) Marine biogeographic disjunction in central New Zealand. Marine Biology, 147(4), 1045-1052.

Baco, A.R., Etter, R.J., Ribeiro, P.A., Heyden, S., Beerli, P. \& Kinlan, B.P. (2016) A synthesis of genetic connectivity in deep-sea fauna and implications for marine reserve design. Molecular Ecology, 25(14), 3276-3298.

Bax, N., Williamson, A., Aguero, M., Gonzalez, E. \& Geeves, W. (2003) Marine invasive alien species: a threat to global biodiversity. Marine Policy, 27(4), $313-323$.

Bay, L.K., Crozier, R.H. \& Caley, M.J. (2006) The relationship between population genetic structure and pelagic larval duration in coral reef fishes on the Great Barrier Reef. Marine Biology, 149(5), 1247-1256.

Bell, J.J. (2008) Connectivity between island marine protected areas and the mainland. Biological Conservation, 141(11), 2807-2820.

Beu, A.G. (1969) Index macrofossils and New Zealand Pliocene and Lower Pleistocene time-stratigraphy. New Zealand Journal of Geology and Geophysics, 12, 643-658.

Beu, A.G. (1999) Fossil records of the cold-water scallop Zygochlamys delicatula (Mollusca: Bivalvia) off northernmost New Zealand: how cold was the Last Glacial Maximum? New Zealand Journal of Geology and Geophysics, 42, $543-550$.

Beu, A.G. (2004) Marine Mollusca of oxygen isotope stages of the last 2 million years in New Zealand. Part 1: Revised generic positions and recognition of warm-water and cool-water migrants. Journal of the Royal Society of New Zealand, 34(2), 111-265. 
Beu, A.G. (2012) Marine Mollusca of the last 2 million years in New Zealand. Part 5: Summary. Journal of the Royal Society of New Zealand, 42(1), 1-47.

Beu, A.G. \& Cernohorsky, W.O. (1986) Taxonomy of gastropods of the families Ranellidae (= Cymatiidae) and Bursidae. Part 1: Adoption of Ranellidae and review of Linatella Gray, 1857. New Zealand Journal of Zoology, 13, 241266.

Beu, A.G. \& Maxwell, P.A. (1990) Cenozoic Mollusca of New Zealand. New Zealand Geological Survey Paleontological Bulletin, 58, 1-518.

Bouchet, P \& Rocroi, J.-P. (2005) Classification and nomenclator of gastropod families. Malacologia, 47, 1-397.

Bowman, M.J., Kibblewhite, A.C., Murtagh, R.A., Chiswell, S.M. \& Sanderson, B.G. (1983) Circulation and mixing in greater Cook Strait, New Zealand. Oceanologica Acta, 6(4), 383-391.

Bradbury, I.R., Laurel, B., Snelgrove, P.V., Bentzen, P. \& Campana, S.E. (2008) Global patterns in marine dispersal estimates: the influence of geography, taxonomic category and life history. Proceedings of the Royal Society of London B: Biological Sciences, 275(1644), 1803-1809.

Bradford, J.M. (1983) Plankton and primary productivity in the vicinity of the Chatham Rise. New Zealand Oceanographic Institute Oceanographic Summary, 21, 1-14.

Bradford-Grieve, J.M., Lewis, K.B. \& Stanton, B.R. (1991) Advances in New Zealand oceanography, 1967-91. New Zealand Journal of Marine and Freshwater Research, 25(4), 429-441.

Buchanan, J. \& Zuccarello, G.C. (2012) Decoupling of short-and long-distance dispersal pathways in the endemic New Zealand seaweed Carpophyllum 
maschalocarpum (Phaeophyceae, Fucales). Journal of Phycology, 48(3), 518529.

Bunce, M., Worthy, T.H., Phillips, M.J., Holdaway, R.N., Willerslev, E., Haile, J., Shapiro, B., Schofield, R.P., Drummond, A., Kamp, P.J.J. \& Cooper, A. (2009) The evolutionary history of the extinct ratite moa and New Zealand Neogene paleogeography. Proceedings of the National Academy of Sciences of the United States of America, 106(49), 20646-20651.

Burton, R.S. (1998) Intraspecific phylogeography across the Point Conception biogeographic boundary. Evolution, 52(3), 734-745.

Butler, E.C.V., Butt, J.A., Lindstrom, E.J., Teldesley, P.C., Pickmere, S. \& Vincent, W.F. (1992) Oceanography of the Subtropical Convergence zone around southern New Zealand. New Zealand Journal of Marine and Freshwater Research, 26(2), 131-154.

Campbell, H.J. (1998) Fauna and flora of the Chatham Islands: less than 4 m.y. old? Geology and Genes, 97, 15-16.

Campbell, H.J. \& Landis, C.A. (2003) New Zealand awash. New Zealand Geographic, 51, 6-7.

Carlton, J.T. (1999) Molluscan invasions in marine and estuarine communities. Malacologia, 41(2), 439-454.

Carlton, J.T. (2011) Ballast. 43-49. In: Simberloff, D. \& Rejmánek, M. (Eds.) Encyclopedia of biological invasions, 3. University of California Press, Berkeley, California.

Carrasco, S.A. and Phillips, N.E. (2012) Differential vulnerability to predation in two sympatric whelks is mediated by juvenile traits. Invertebrate Biology, 131(3), 187-196. 
Carrasco, S.A., Phillips, N.E. and Pérez-Matus, A. (2012) Offspring size and maternal environments mediate the early juvenile performance of two congeneric whelks. Marine Ecology Progress Series, 459, 73-83.

Carter, L., Garlick, R.D. \& Sutton, P. (1998) New Zealand regional currents (Ocean Circulation). National Institute of Water and Atmospheric Research Chart Miscellaneous Series, 76.

Carter, R.M. (2005) A New Zealand climatic template back to c. 3.9 Ma: ODP Site 1119, Canterbury Bight, south-west Pacific Ocean, and its relationship to onland successions. Journal of the Royal Society of New Zealand, 35, 9-42.

Carvalho, G.R. \& Hauser, L. (1994) Molecular genetics and the stock concept in fisheries. Reviews in Fish Biology and Fisheries, 4, 326-350.

Castro, J.J., Santiago, J.A. \& Santana-Ortega, A.T. (2002) A general theory on fish aggregation to floating objects: an alternative to the meeting point hypothesis. Reviews in Fish Biology and Fisheries, 11(3), 255-277.

Chapple, D.G., Ritchie, P.A. \& Daugherty, C.H. (2009) Origin, diversification, and systematics of the New Zealand skink fauna (Reptilia: Scincidae). Molecular Phylogenetics and Evolution, 52, 470-487.

Chiswell, S.M. (1994) Acoustic Doppler Current Profiler measurements over the Chatham Rise. New Zealand Journal of Marine and Freshwater Research, 28, $167-178$.

Chiswell, S.M. \& Booth, J.D. (1999) Rock lobster Jasus edwardsii larval retention by the Wairarapa Eddy off New Zealand. Marine Ecology Progress Series, 183, $227-240$.

Chiswell, S.M., Bostock, H.C., Sutton, P.J. \& Williams, M.J. (2015) Physical oceanography of the deep seas around New Zealand: a review. New Zealand Journal of Marine and Freshwater Research, 49(2), 286-317. 
Chiswell, S.M. \& Roemmich, D. (1998) The East Cape Current and two eddies: a mechanism for larval retention? New Zealand Journal of Marine and Freshwater Research, 32(3), 385-397.

Chiswell, S.M., Toole, J. \& Church, J. (1997) Transports across the Tasman Sea from WOCE repeat sections: the East Australian Current 1990-94. New Zealand Journal of Marine and Freshwater Research, 31(4), 469-475.

Claessens, L., Veldkamp, A., ten Broeke, E.M. \& Vloemans, H. (2009) A Quaternary uplift record for the Auckland region, North Island, New Zealand, based on marine and fluvial terraces. Global and Planetary change, 68(4), 383-394.

Claudet, J. \& Pelletier, D. (2004) Marine protected areas and artificial reefs: a review of the interactions between management and scientific studies. Aquatic Living Resources, 17(2), 129-138.

Close, R.C., Moar, N.T., Tomlinson, A.I. \& Lowe, A.D. (1978) Aerial dispersal of biological material from Australia to New Zealand. International Journal of Biometeorology, 22(1), 1-19.

Collins, C.J., Fraser, C.I., Ashcroft, A. \& Waters, J.M. (2010) Asymmetric dispersal of southern bull-kelp (Durvillaea antarctica) adults in coastal New Zealand: testing an oceanographic hypothesis. Molecular Ecology, 19(20), 4572-4580.

Collin, R. (2004) Phylogenetic effects, the loss of complex characters, and the evolution of development in calyptraeid gastropods. Evolution, 58(7), 14881502 .

Cooper, R.A., Maxwell, P.A., Crampton, J.S., Beu, A.G., Jones, C.M. \& Marshall, B.A. (2006) Completeness of the fossil record: estimating losses due to small body size. Geology, 34(4), 241-244. 
Crampton, J.S., Beu, A.G., Cooper, R.A., Jones, C.M., Marshall, B.A. \& Maxwell, P.A. (2003) Estimating the rock volume bias in paleobiodiversity studies. Science, 301, 358-360.

Craw, R. (1988) Continuing the synthesis between panbiogeography, phylogenetic systematics and geology as illustrated by empirical studies on the biogegraphy of New Zealand and the Chatham Islands. Systematic Zoology, 37, 291-310.

Craw, R. (1989) New Zealand biogeography: a panbiogeographic approach. New Zealand Journal of Zoology, 16, 527-547.

Cruickshank, T.E. \& Hahn, M.W. (2014) Reanalysis suggests that genomic islands of speciation are due to reduced diversity, not reduced gene flow. Molecular Ecology, 23(13), 3133-3157.

Dell, R.K. (1956) The archibenthal Mollusca of New Zealand. Dominion Museum Bulletin, 18, 1-235.

Dell, R.K. (1960) Chatham Islands marine mollusca based upon the collections of the Chatham Islands Expedition, 1954. New Zealand Department of Scientific and Industrial Research Bulletin, 139, 141-157.

Dell, R.K. (1962) New Zealand marine provinces - do they exist? Tuatara, 10(1), 43 51.

Dohner, M. (2016) Crawling to connectivity? The direct-developing journey of the spotted whelk (Cominella maculosa). MSc thesis. Victoria University of Wellington, New Zealand.

Donald, K.M., Winter, D.J., Ashcroft, A.L. \& Spencer, H.G. (2015) Phylogeography of the whelk genus Cominella (Gastropoda: Buccinidae) suggests longdistance counter-current dispersal of a direct developer. Biological Journal of the Linnean Society, 115, 315-332. 
Donoghue, M.J. (1985) A critique of the biological species concept and recommendations for a phylogenetic alternative. Bryologist, 88(3), 172-181.

Drummond, A.J., Rambaut, A., Shapiro, B. \& Pybus, O.G. (2005) Bayesian coalescent inference of past population dynamics from molecular sequences. Molecular Biology and Evolution, 22(5), 1185-1192.

Dwyer, G.S. \& Chandler, M.A. (2009) Mid-Pliocene sea level and continental ice volume based on coupled benthic $\mathrm{Mg} / \mathrm{Ca}$ palaeotemperatures and oxygen isotopes. Philosophical Transactions of the Royal Society of London A: Mathematical, Physical and Engineering Sciences, 367(1886), 157-168.

Excoffier, L. \& Lischer, H.E. (2010) Arlequin suite ver 3.5: a new series of programs to perform population genetics analyses under Linux and Windows. Molecular Ecology Resources, 10(3), 564-567.

Finlay, H.J. (1928) The recent Mollusca of the Chatham Islands. Transactions of the New Zealand Institute, 59, 232-286.

Fleming, A., Dohner, M., Phillips, N.E. \& Ritchie, P.A. (in review) Genetic connectivity among populations of two congeneric direct-developing whelks varies across spatial scales. New Zealand Journal of Marine and Freshwater Research.

Fleming, C.A. (1953) The geology of Wanganui subdivision, Waverley and Wanganui sheet districts (N137-138). New Zealand Geological Survey Bulletin, 52, 1-362.

Fleming, C.A. (1979) The geological history of New Zealand and its life. Auckland University Press, Auckland, New Zealand.

Fleming, K., Johnston, P., Zwartz, D., Yokoyama, Y., Lambeck, K. \& Chappell, J. (1998) Refining the eustatic sea-level curve since the Last Glacial Maximum 
using far- and intermediate-field sites. Earth and Planetary Science Letters, 163(1), 327-342.

Folmer, O., Black, M., Hoeh, W., Lutz, R. \& Vrijenhoek, R. (1994) DNA primers for amplification of mitochondrial cytochrome c oxidase subunit I from diverse metazoan invertebrates. Molecular Marine Biology and Biotechnology, 3(5), 294-299.

Foster, B.A. (1986) Barnacles in Maori middens. Journal of the Royal Society of New Zealand, 16(1), 43-49.

Fraser, C.I., Nikula, R., Ruzzante, D.E. \& Waters, J.M. (2012) Poleward bound: biological impacts of Southern Hemisphere glaciation. Trends in Ecology and Evolution, 27(8), 462-471.

Fraser, C.I., Nikula, R. \& Waters, J.M. (2011) Oceanic rafting by a coastal community. Proceedings of the Royal Society of London B: Biological Sciences, 278(1706), 649-655.

Frusin, A. (1982) Electrophoretic study of some paua (Haliotis iris) proteins. MSc thesis. Victoria University of Wellington, New Zealand.

Fu, Y.X. (1997) Statistical tests of neutrality of mutations against population growth, hitchhiking and background selection. Genetics, 147(2), 915-925.

Gardner, J.P.A, Bell, J., Constable, H., Hannan, D., Ritchie, P.A. \& Zuccarello, G. (2010) Multi-species coastal marine connectivity: a literature review with recommendations for further research. New Zealand Aquatic Environment and Biodiversity Report, 58.

Gardner, J.P.A., Pande, A., Eyles, R.F. \& Wear, R.G. (1996) Biochemical genetic variation among populations of the greenshell mussel, Perna canaliculus, from New Zealand: preliminary findings. Biochemical Systematics and Ecology, 24(7), 763-774. 
Giribet, G. \& Boyer, S. (2010) 'Moa's Ark' or 'Goodbye Gondwana': is the origin of New Zealand's terrestrial invertebrate fauna ancient, recent, or both? Invertebrate Systematics, 24, 1-8.

Godfrey, J.S., Cresswell, G.R., Golding, T.J., Pearce, A.F. \& Boyd, R. (1980) The separation of the East Australian Current. Journal of Physical Oceanography, $10(3), 430-440$.

Goldstien, S.J. (2005) Phylogeography of the Cellana limpets of New Zealand: investigating barriers to marine dispersal and historical biogeography. $\mathrm{PhD}$ thesis. University of Canterbury, Christchurch, New Zealand.

Goldstien, S.J., Schiel, D.R. \& Gemmell, N.J. (2006) Comparative phylogeography of coastal limpets across a marine disjunction in New Zealand. Molecular Ecology, 15, 3259-3268.

Gordon, D.P., Beaumont, J., MacDiarmid, A., Robertson, D.A. \& Ahyong, S.T. (2010) Marine biodiversity of Aotearoa New Zealand. PLoS One, 5(8), e10905.

Graham, D.H. (1941) Breeding habits of twenty-two species of marine Mollusca. Transactions and Proceedings of the Royal Society of New Zealand, 71(2), $152-159$.

Greaves, S.N., Chapple, D.G., Daugherty, C.H., Gleeson, D.M. \& Ritchie, P.A. (2008) Genetic divergences pre-date Pleistocene glacial cycles in the New Zealand speckled skink, Oligosoma infrapunctatum. Journal of Biogeography, $35(5), 853-864$.

Guindon, S., Dufayard, J.F., Lefort, V., Anisimova, M., Hordijk, W. \& Gascuel, O. (2010) New algorithms and methods to estimate maximum-likelihood phylogenies: assessing the performance of PhyML 3.0. Systematic Biology, 59(3), 301-321. 
Guindon, S. \& Gascuel, O. (2003) A simple, fast, and accurate algorithm to estimate large phylogenies by maximum likelihood. Systematic Biology, 52(5), 696704.

Hannan, D.A., Constable, H.B., Silva, C.N.S., Bell, J.J., Ritchie, P.A. \& Gardner, J.P.A. (2016) Genetic connectivity amongst New Zealand's open sandy shore and estuarine coastal taxa. New Zealand Aquatic Environment and Biodiversity Report, 172.

Harasewych, M.G. (1998) Family Buccinidae. 825-827. In: Beesley, P.L., Ross, G.J.B. \& Wells, A. (Eds.) Mollusca: The southern synthesis. Fauna of Australia, 5, CSIRO Publishing, Melbourne, Australia.

Harasewych, M.G. \& Kantor, Y.I. (1999) A revision of the Antarctic genus Chlanidota (Gastropoda: Neogastropoda: Buccinulidae). Proceedings of the Biological Society of Washington, 112, 253-302.

Hardy, S.M., Carr, C.M., Hardman, M., Steinke, D., Corstorphine, E. \& Mah, C. (2011) Biodiversity and phylogeography of Arctic marine fauna: insights from molecular tools. Marine Biodiversity, 41(1), 195-210.

Harpending, H.C. (1994) Signature of ancient population growth in a low-resolution mitochondrial DNA mismatch distribution. Human Biology, 66(4), 591-600.

Harpending, H.C., Sherry, S.T., Rogers, A.R. \& Stoneking, M. (1993) The genetic structure of ancient human populations. Current Anthropology, 34(4), 483496.

Hayashi, S. (2005) The molecular phylogeny of the Buccinidae (Caenogastropoda: Neogastropoda) as inferred from the complete mitochondrial 16S rRNA gene sequences of selected representatives. Molluscan Research, 25, 85-98. 
Haye, P.A., Segovia, N.I., Muñoz-Herrera, N.C., Gálvez, F.E., Martínez, A., Meynard, A., Pardo-Gandarillas, M.C., Paulin, E. \& Faugeron, S. (2014) Phylogeographic structure in benthic marine invertebrates of the southeast Pacific coast of Chile with differing dispersal potential. PLoS One, 9(2), e88613.

Hayes, M.L., Johnson, M.E. \& Fox, W.T. (1993) Rocky-shore biotic associations and their fossilization potential: Isla Requeson (Baja California Sur, Mexico). Journal of Coastal Research, 9(4), 944-957.

Hayward, B.W. (1982) Prehistoric archaeological sites on Little Barrier Island, New Zealand. Tane, 28, 67-78.

Hayward, B.W., Moore, P.R. \& Newman, M. (1978) Archaeological site survey of Hen Island (Taranga). Tane, 24, 137-157.

Hayward, B.W. \& Morley, M.S. (2002) Intertidal biota of the proposed Nga Motu Marine Reserve, New Plymouth. Poirieria, 28, 1-11.

Hayward, B.W., Morley, M.S., Blom, W., Grenfell, H.R., Smith, N., Rogan, D. and Stephenson, A.B. (2002) Marine biota of Raglan, Waikato West Coast. Poirieria, 28, 1-17.

Hayward, B.W., Morley, M.S., Stephenson, A.B., Blom, W., Grenfell, H.R. \& Prasad, R. (1999) Marine biota of the north Taranaki coast, New Zealand. Tane, 37, 171-199.

Heads, M. (1998) Biogeographic disjunction along the Alpine Fault, New Zealand. Biological Journal of the Linnean Society, 63, 161-176.

Heath, R.A. (1981) Oceanic fronts around southern New Zealand. Deep Sea Research Part A. Oceanographic Research Papers, 28(6), 547-560. 
Hewitt, C.L., Gollasch, S. \& Minchin, D. (2009) The vessel as a vector-biofouling, ballast water and sediments. 117-131. In: Rilov, G. \& Crooks, J.A. (Eds.) Biological invasions in marine ecosystems. Springer-Verlag, Berlin.

Hey, J. \& Nielsen, R. (2004) Multilocus methods for estimating population sizes, migration rates and divergence time, with applications to the divergence of Drosophila pseudoobscura and D. persimilis. Genetics, 167(2), 747-760.

Hills, S.F., Trewick, S.A. \& Morgan-Richards, M. (2011) Phylogenetic information of genes, illustrated with mitochondrial data from a genus of gastropod molluscs. Biological Journal of the Linnean Society, 104(4), 770-785.

Hoernle, K., White, J.D.L., van den Bogaard, P., Hauff, F., Coombs, D.S., Werner, R., Timm, C., Garbe-Schönberg, D., Reay, A. \& Cooper, A.F. (2006) Cenozoic intraplate volcanism on New Zealand: upwelling induced by lithospheric removal. Earth and Planetary Science Letters, 248(1), 350-367.

Holmes, E.E., Lewis, M.A., Banks, J.E. \& Veit, R.R. (1994) Partial differential equations in ecology: spatial interactions and population dynamics. Ecology, 75(1), 17-29.

Huelsenbeck, J.P. \& Ronquist, F. (2001) MRBAYES: Bayesian inference of phylogenetic trees. Bioinformatics, 17(8), 754-755.

ICZN Opinion 479 (1957) Validation under the plenary powers of specific names for nine species of the class Gastropoda occurring in the New Zealand area as published by Martyn (T.) in 1784 in the work entitled "The Universal Conchologist". Opinions and Declarations Rendered by the International Commission on Zoological Nomenclature, 16, 367-416.

Jennings, S., Reynolds, J.D. \& Polunin, N.V. (1999) Predicting the vulnerability of tropical reef fishes to exploitation with phylogenies and life histories. Conservation Biology, 13(6), 1466-1475. 
Kamp, P.J.J. (1986) Late Cretaceous-Cenozoic tectonic development of the southwest Pacific region. Tectonophysics, 121(2-4), 225-251.

Kano, Y. (2006) Usefulness of the opercular nucleus for inferring early development in neritimorph gastropods. Journal of Morphology, 267(9), 1120-1136.

Kantor, Y.I. (2003) Comparative anatomy of the stomach of Buccinoidea (Neogastropoda). Journal of Molluscan Studies, 69, 203-222.

Kearse, M., Moir, R., Wilson, A., Stones-Havas, S., Cheung, M., Sturrock, S., Buxton, S., Cooper, A., Markowitz, S., Duran, C., Thierer, T., Ashton, B., Meintjes, P. \& Drummond, A. (2012) Geneious Basic: an integrated and extendable desktop software platform for the organization and analysis of sequence data. Bioinformatics, 28(12), 1647-1649.

Keeney, D.B., King, T.M., Rowe, D.L. \& Poulin, R. (2009) Contrasting mtDNA diversity and population structure in a direct-developing marine gastropod and its trematode parasites. Molecular Ecology, 18(22), 4591-4603.

Keeney, D.B., Szymaniak, A.D. \& Poulin, R. (2013) Complex genetic patterns and a phylogeographic disjunction among New Zealand mud snails Zeacumantus subcarinatus and Z. lutulentus. Marine Biology, 160(6), 1477-1488.

Kenny, J.A., Lindsay, J.M. \& Howe, T.M. (2012) Post-Miocene faults in Auckland: insights from borehole and topographic analysis. New Zealand Journal of Geology and Geophysics, 55(4), 323-343.

Knox, M.A., Hogg, I.D. \& Pilditch, C.A. (2011) The role of vicariance and dispersal on New Zealand's estuarine biodiversity: the case of Paracorophium (Crustacea: Amphipoda). Biological Journal of the Linnean Society, 103(4), 863-874.

Koch, C.F. (1978) Bias in the published fossil record. Paleobiology, 4(3), 367-372. 
Kojima, S., Hayashi, I., Kim, D., Iijima, A. \& Furota, T. (2004) Phylogeography of an intertidal direct-developing gastropod Batillaria cumingi around the Japanese Islands. Marine Ecology Progress Series, 276, 161-172.

Kosyan, A.R. \& Kantor, Y.I. (2004) Morphology, taxonomic status and relationships of Melongenidae (Gastropoda: Neogastropoda). Ruthenica, 14, 9-36.

Kosyan, A.R. \& Kantor, Y.I. (2007) Morphological phylogenetic analysis of gastropods from family Buccinidae. Doklady Biological Sciences, 415, 270272.

Laikre, L., Palm, S. \& Ryman, N. (2005) Genetic population structure of fishes: implications for coastal zone management. Ambio, 34(2), 111-119.

Lamarck, [J.B.P.A.de M.de.] (1816) Tableau encyclopédique et méthodique des trois regnes de la nature. Vingt-troisième partie. Mollusques et polypes divers. Agasse, Paris. "Liste des objets représentés dans les planches de cette livraison."

Lamarck, [J.B.P.A.de M.de.] (1822) Histoire naturelle des animaux sans vértébres. 7, Jardin du Roi, Paris.

Lambeck, K., Yokoyama, Y. \& Purcell, T. (2002) Into and out of the Last Glacial Maximum: sea-level change during Oxygen Isotope Stages 3 and 2. Quaternary Science Reviews, 21(1), 343-360.

Landis, C.A., Campbell, H.J., Begg, J.G., Mildenhall, D.C., Paterson, A.M. \& Trewick, S.A. (2008) The Waipounamu Erosion Surface: questioning the antiquity of the New Zealand land surface and terrestrial fauna and flora. Geological Magazine, 145(2), 173-197.

Laurel, B.J. \& Bradbury, I.R. (2006) "Big” concerns with high latitude marine protected areas (MPAs): trends in connectivity and MPA size. Canadian Journal of Fisheries and Aquatic Sciences, 63(12), 2603-2607. 
Leaché, A.D. \& McGuire, J.A. (2006) Phylogenetic relationships of horned lizards (Phrynosoma) based on nuclear and mitochondrial data: evidence for a misleading mitochondrial gene tree. Molecular Phylogenetics and Evolution, $39(3), 628-644$.

Lewis, K.B., Carter, L. \& Davey, F.J. (1994) The opening of Cook Strait: interglacial tidal scour and aligning basins at a subduction to transform plate edge. Marine Geology, 116(3), 293-312.

Li, H. \& Durbin, R. (2011) Inference of human population history from individual whole-genome sequences. Nature, 475(7357), 493-496.

Librado, P. \& Rozas, J. (2009) DnaSP v5: a software for comprehensive analysis of DNA polymorphism data. Bioinformatics, 25(11), 1451-1452.

Liggins, L., Chapple, D.G., Daugherty, C.H. \& Ritchie, P.A. (2008) A SINE of restricted gene flow across the Alpine Fault: phylogeography of the New Zealand common skink (Oligosoma nigriplantare polychroma). Molecular Ecology, 17(16), 3668-3683.

Lowe, W.H. \& Allendorf, F.W. (2010) What can genetics tell us about population connectivity? Molecular Ecology, 19(15), 3038-3051.

Magallón, S.A. (2004) Dating lineages: molecular and paleontological approaches to the temporal framework of clades. International Journal of Plant Sciences, 165(4), 7-21.

Manel, S., Schwartz, M.K., Luikart, G. \& Taberlet, P. (2003) Landscape genetics: combining landscape ecology and population genetics. Trends in Ecology and Evolution, 18(4), 189-197.

Marra, M.J., Alloway, B.V. \& Newnham, R.M. (2006) Paleoenvironmental reconstruction of a well-preserved Stage 7 forest sequence catastrophically 
buried by basaltic eruptive deposits, northern New Zealand. Quaternary Science Reviews, 25(17), 2143-2161.

Marshall, B.A. (1993) The systematic position of Larochea Finlay, 1927, and introduction of a new genus and two new species (Gastropoda: Scissurellidae) Journal of Molluscan Studies, 59, 285-294.

Marshall, B.A. (1995) A revision of the recent Calliostoma species of New Zealand (Mollusca: Gastropoda: Trochoidea). The Nautilus, 108, 83-127.

Marshall, B.A. (1998a) A review of the recent Trochini of New Zealand (Mollusca: Gastropoda: Trochidae). Molluscan Research, 19(1), 73-106.

Marshall, B.A. (1998b) The New Zealand recent species of Cantharidus Montfort, 1810 and Micrelenchus Finlay, 1926 (Mollusca: Gastropoda: Trochidae). Molluscan Research, 19(1), 107-156.

Marshall, B.A. (2003) A review of the recent and Late Cenozoic Calyptraeidae of New Zealand (Mollusca: Gastropoda). The Veliger, 46(2), 117-144.

Marshall, B.A., Puillandre, N., Lambourdière, J., Couloux, A. \& Samadi, S. (2016) Deep-Sea wood-eating limpets of the genus Pectinodonta Dall, 1882 (Mollusca: Gastropoda: Patellogastropoda: Pectinodontidae) from the tropical West Pacific. 235-265. In: Héros, V., Strong, E. \& Bouchet, P. (Eds.) Tropical Deep-Sea Benthos, 29. Mémoires du Muséum National d'Histoire Naturelle, 208. Paris.

Marshall, B.A. \& Walton, K. (2015) New records of intertidal and shallow sub-tidal (to $30 \mathrm{~m}$ ) Mollusca from the Chatham Islands. Cookia, 27, 2-3.

Marston, O.J. (1996) The Mollusca of the Chatham Islands - 1994. Cookia, 7(3), 1556.

Marston, O.J. (1998) Chatham Islands visits, 1996 to 1997. Cookia, 9, 12-30. 
Marwick, J. (1965) Upper Cenozoic Mollusca of Wairoa District, Hawkes Bay. New Zealand Geological Society Paleontological Bulletin, 39, 1-83.

Mayr, E. (1954) Geographic speciation in tropical echinoids. Evolution, 8(1), 1-18.

Mayr, E. (1957) Species concepts and definitions. 1-22. In: Mayr, E. (Ed.) The Species Problem. American Association for the Advancement of Science, 50, Washington DC.

Mayr, E. (1992) A local flora and the biological species concept. American Journal of Botany, 79(2), 222-238.

McEdward, L.R. \& Janies, D.A. (1997) Relationships among development, ecology, and morphology in the evolution of echinoderm larvae and life cycles. Biological Journal of the Linnean Society, 60(3), 381-400.

McEdward, L.R. \& Miner, B.G. (2001) Larval and life-cycle patterns in echinoderms. Canadian Journal of Zoology, 79(7), 1125-1170.

McHugh, D. \& Rouse, G.W. (1998) Life history evolution of marine invertebrates: new views from phylogenetic systematics. Trends in Ecology and Evolution, 13(5), 182-186.

Mileikovsky, S.A. (1971) Types of larval development in marine bottom invertebrates, their distribution and ecological significance: a re-evaluation. Marine Biology, 10, 193-213.

Mills, L.S. \& Allendorf, F.W. (1996) The one-migrant-per-generation rule in conservation and management. Conservation Biology, 10(6), 1509-1518.

Moore, P.R. \& Kenny, J.A. (1986) Exotic rocks on the northern New Zealand coast: a probable association with early shipwrecks. Tane, 31, 125-131. 
Morgan, E.M., Green, B.S., Murphy, N.P. \& Strugnell, J.M. (2013) Investigation of genetic structure between deep and shallow populations of the southern rock lobster, Jasus edwardsii in Tasmania, Australia. PloS One, 8(10), e77978.

Moreley, M.S. (2013) In a whorl with Cominella glandiformis. Poirieria, 37, 4-7.

Morley, M.S., Hayward, B.W., Raven, J.L., Foreman, G.A. \& Grenfell, H.R. (2006). Intertidal and shallow subtidal biota of Mahia Peninsula, Hawkes Bay. Records of the Auckland Museum, 43, 11-41.

Morley, M.S., Hayward, B.W., Stephenson, A.B., Smith, N. \& Riley, J.L. (1997) Molluscs, Crustacea and echinoderms from Kawhia, west coast, North Island. Tane, 36, 157-180.

Mortimer, N., Campbell, H.J., Tulloch, A.J., King, P.R., Stagpoole, V.M., Wood, R.A., Rattenbury, M.S., Sutherland, R., Adams, C.J., Collot, J. \& Seton, M. (2017) Zealandia: earth's hidden continent. Geological Society of America Today, 27(3), doi: 10.1130/GSATG321A.1

Morton, J. \& Miller, M. (1968) The New Zealand sea shore. Collins, Auckland, New Zealand.

Mueller, U.G. \& Wolfenbarger, L.L. (1999) AFLP genotyping and fingerprinting. Trends in Ecology and Evolution, 14(10), 389-394.

Naish, T.R. \& Wilson, G.S. (2009) Constraints on the amplitude of Mid-Pliocene (3.6-2.4 Ma) eustatic sea-level fluctuations from the New Zealand shallowmarine sediment record. Philosophical Transactions of the Royal Society of London A: Mathematical, Physical and Engineering Sciences, 367(1886), 169-187.

Nikula, R., Fraser, C.I., Spencer, H.G. \& Waters, J.M. (2010) Circumpolar dispersal by rafting in two subantarctic kelp-dwelling crustaceans. Marine Ecology Progress Series, 405, 221-230. 
Nikula, R., Spencer, H.G. \& Waters, J.M. (2011a) Comparison of population-genetic structuring in congeneric kelp-versus rock-associated snails: a test of a dispersal-by-rafting hypothesis. Ecology and Evolution, 1(2), 169-180.

Nikula, R., Spencer, H.G. \& Waters, J.M. (2011b) Evolutionary consequences of microhabitat: population-genetic structuring in kelp-vs. rock-associated chitons. Molecular ecology, 20(23), 4915-4924.

O’Neill, S.B., Chapple, D.G., Daugherty, C.H. \& Ritchie, P.A. (2008) Phylogeography of two New Zealand lizards: McCann's skink (Oligosoma maccanni) and the brown skink (O. zelandicum). Molecular Phylogenetics and Evolution, 48(3), 1168-1177.

Ovenden, J.R. (2013) Crinkles in connectivity: combining genetics and other types of biological data to estimate movement and interbreeding between populations. Marine and Freshwater Research, 64(3), 201-207.

Ovenden, J.R., Brasher, D.J. \& White, R.W.G. (1992) Mitochondrial DNA analyses of the red rock lobster Jasus edwardsii supports an apparent absence of population subdivision throughout Australasia. Marine Biology, 112(2), 319326.

Palumbi, S.R. (1994) Genetic divergence, reproductive isolation, and marine speciation. Annual Review of Ecology and Systematics, 25(1), 547-572.

Palumbi, S.R. (2003) Population genetics, demographic connectivity, and the design of marine reserves. Ecological Applications, 13, 146-158.

Parrish, J.K. \& Edelstein-Keshet, L. (1999) Complexity, pattern, and evolutionary trade-offs in animal aggregation. Science, 284(5411), 99-101. 
Pilkington, M.C. (1974) The eggs and hatching stages of some New Zealand prosobranch molluscs. Journal of the Royal Society of New Zealand, 4(4), 411-431.

Ponder, W.F. (1965a) A revision of the New Zealand recent species previously known as Notosetia Iredale, 1915 (Rissoidae, Gastropoda). Records of the Auckland Institute and Museum, 6(2), 101-131.

Ponder, W.F. (1965b) A revision of the New Zealand recent and fossil species of Estea Iredale, 1915. Records of the Auckland Institute and Museum, 6(2), 131161.

Ponder, W.F. (1972) A review of the genus Xymene Iredale of New Zealand (Mollusca: Muricidae). Journal of the Royal Society of New Zealand, 2(4), 471-499.

Ponder, W.F. (1973) The origin and evolution of the Neogastropoda. Malacologia, $12,295-338$.

Powell, A.W.B. (1929) The recent and Tertiary species of the genus Buccinulum in New Zealand, with a review of related genera and families. Transactions of the New Zealand Institute, 60, 57-101.

Powell, A.W.B. (1937) The shellfish of New Zealand. An illustrated handbook. Unity Press, Auckland.

Powell, A.W.B. (1946) New species of New Zealand Mollusca from the South Island, Stewart Island and Chatham Islands. Records of the Auckland Institute and Museum, 3, 137-144.

Powell, A.W.B. (1952) New Zealand molluscan systematics, with descriptions of new species, part 1. Records of the Auckland Institute and Museum, 4(3), 169-185. 
Proctor, R. \& Carter, L. (1989) Tidal and sedimentary response to the Late Quaternary closure and opening of Cook Strait, New Zealand: results from numerical modelling. Paleoceanography, 4, 167-180.

Quoy, J.C.R. \& Gaimard, P. (1833) Voyage de découverts de l'Astrolabe, exécuté par ordre du Roi pendant les années 1826-1827-1828-1829, sous le commandement de M.J. Dumont d'Urville. Zoologie. Mollusques, 2(2). Tastu, Paris.

Rambaut, A. \& Drummond, A.J. (2012) FigTree version 1.4.0. Available at: www.tree.bio.ed.ac.uk/software/figtree.

Reisser, C.M., Marshall, B.A. \& Gardner, J.P.A. (2012) A morphometric approach supporting genetic results in the taxonomy of the New Zealand limpets of the Cellana strigilis complex (Mollusca: Patellogastropoda: Nacellidae). Invertebrate Systematics, 26(2), 193-203.

Rice, W.R. \& Hostert, E.E. (1993) Laboratory experiments on speciation: what have we learned in 40 years? Evolution, 47(6), 1637-1653.

Ridgway, K.R. \& Dunn, J.R. (2003) Mesoscale structure of the mean East Australian Current System and its relationship with topography. Progress in Oceanography, 56(2), 189-222.

Rocha, L.A., Craig, M.T. \& Bowen, B.W. (2007) Phylogeography and the conservation of coral reef fishes. Coral Reefs, 26(3), 501-512.

Ross, P.M., Hogg, I.D., Pilditch, C.A. \& Lundquist, C.J. (2009) Phylogeography of New Zealand's coastal benthos. New Zealand Journal of Marine and Freshwater Research, 43, 1009-1027.

Ross, P.M., Hogg, I.D., Pilditch, C.A., Lundquist, C.J. \& Wilkins, R.J. (2012) Population genetic structure of the New Zealand estuarine clam Austrovenus stutchburyi (Bivalvia: Veneridae) reveals population subdivision and partial 
congruence with biogeographic boundaries. Estuaries and Coasts, 35(1), 143154.

Ruiz, G.M. \& Carlton, J. (2003) Invasive species: vectors and management strategies. Island Press, Washington DC.

Rydin, C., Pedersen, K.R. \& Friis, E.M. (2004) On the evolutionary history of Ephedra: Cretaceous fossils and extant molecules. Proceedings of the National Academy of Sciences, 101(47), 16571-16576.

Sambrook, J., Fritsch, E.F. \& Maniatis, T. (1989) Molecular cloning: a lab manual 3. Cold Spring Harbour Laboratory Press, New York.

Sánchez, R., Sepúlveda, R.D., Brante, A. and Cárdenas, L. (2011) Spatial pattern of genetic and morphological diversity in the direct developer Acanthina monodon (Gastropoda: Mollusca). Marine Ecology Progress Series, 434, 121131.

Sandiford, A., Horrocks, M., Newnham, R., Ogden, J. \& Alloway, B. (2002) Environmental change during the last glacial maximum (c. 25 000-c. 16500 years BP) at Mt Richmond, Auckland Isthmus, New Zealand. Journal of the Royal Society of New Zealand, 32(1), 155-167.

Schnabel, K.E., Hogg, I.D. \& Chapman, M.A. (2000) Population genetic structures of two New Zealand corophiid amphipods and the presence of morphologically cryptic species: implications for the conservation of diversity. New Zealand Journal of Marine and Freshwater Research, 34(4), 637-644.

Schoch, C.L., Seifert, K.A., Huhndorf, S., Robert, V., Spouge, J.L., Levesque, C.A., Chen, W. \& Consortium, F.B. (2012) Nuclear ribosomal internal transcribed spacer (ITS) region as a universal DNA barcode marker for fungi. Proceedings of the National Academy of Sciences, 109(16), 6241-6246. 
Schopf, T.J. (1978) Fossilization potential of an intertidal fauna: Friday Harbor, Washington. Paleobiology, 4(3), 261-270.

Shaw, K.L. (2002) Conflict between nuclear and mitochondrial DNA phylogenies of a recent species radiation: what mtDNA reveals and conceals about modes of speciation in Hawaiian crickets. Proceedings of the National Academy of Sciences, 99(25), 16122-16127.

Shears, N.T., Smith, F., Babcock, R.C., Duffy, C.A. \& Villouta, E. (2008) Evaluation of biogeographic classification schemes for conservation planning: application to New Zealand's coastal marine environment. Conservation Biology, 22(2), $467-481$.

Simon, C., Frati, F., Beckenbach, A., Crespi, B., Liu, H. \& Flook, P. (1994) Evolution, weighting and phylogenetic utility of mitochondrial gene sequences and a compilation of conserved polymerase chain reaction primers. Annals of the Entomological Society of America, 87, 651-701.

Slatkin, M. (1987) Gene flow and the geographic structure of natural populations. Science, 236, 787-793.

Smith, P.J. (1988) Biochemical-genetic variation in the green-lipped mussel Perna canaliculus around New Zealand and possible implications for mussel farming. New Zealand Journal of Marine and Freshwater Research, 22(1), 85-90.

Smith, P.J., McKoy, J.L. \& Machin, P.J. (1980) Genetic variation in the rock lobsters Jasus edwardsii and Jasus novaehollandiae. New Zealand Journal of Marine and Freshwater Research, 14(1), 55-63.

Smith, P.J. and McVeagh, S.M. (2006) Genetic population structure of blackfoot paua. Final research report for Ministry of Fisheries project SAP2005-01. (Unpublished report held by Ministry of Fisheries, Wellington). 
Sokal, R.R. \& Crovello, T.J. (1970) The biological species concept: a critical evaluation. The American Naturalist, 104(936), 127-153.

Sponaugle, S., Cowen, R.K., Shanks, A., Morgan, S.G., Leis, J.M., Pineda, J., Boehlert, G.W., Kingsford, M.J., Lindeman, K.C., Grimes, C. \& Munro, J.L. (2002) Predicting self-recruitment in marine populations: biophysical correlates and mechanisms. Bulletin of Marine Science, 70(1), 341-375.

Sponer, R. \& Roy, M.S. (2002) Phylogeographic analysis of the brooding brittle star Amphipholis squamata (Echinodermata) along the coast of New Zealand reveals high cryptic genetic variation and cryptic dispersal potential. Evolution, 56(10), 1954-1967.

Star, B., Apte, S. \& Gardner, J.P.A. (2003) Genetic structuring among populations of the greenshell mussel Perna canaliculus revealed by analysis of randomly amplified polymorphic DNA. Marine Ecology Progress Series, 249, 171-182.

Stevens, M.I. \& Hogg, I.D. (2004) Population genetic structure of New Zealand's endemic corophiid amphipods: evidence for allopatric speciation. Biological Journal of the Linnean Society, 81(1), 119-133.

Stewart, M.J. \& Creese, R.G. (2004) Feeding ecology of whelks on an intertidal sand flat in north-eastern New Zealand. New Zealand Journal of Marine and Freshwater Research, 38, 819-831.

Sunnucks, P. (2000) Efficient genetic markers for population biology. Trends in Ecology and Evolution, 15(5), 199-203.

Swearer, S.E., Shima, J.S., Hellberg, M.E., Thorrold, S.R., Jones, G.P., Robertson, D.R., Morgan, S.G., Selkoe, K.A., Ruiz, G.M. \& Warner, R.R. (2002) Evidence of self-recruitment in demersal marine populations. Bulletin of Marine Science, 70(1), 251-271. 
Tajima, F. (1989) Statistical method for testing the neutral mutation hypothesis by DNA polymorphism. Genetics, 123(3), 585-595.

Teske, P.R., von der Heyden, S., McQuaid, C.D. \& Barker, N.P. (2011) A review of marine phylogeography in southern Africa. South African Journal of Science, $107,43-53$.

Thayer, C.W. (1975) Morphologic adaptations of benthic invertebrates to soft substrata. Journal of Marine Research, 33, 177-189.

Thomas, L. \& Bell, J.J. (2013) Testing the consistency of connectivity patterns for a widely dispersing marine species. Heredity, 111(4), 345-354.

Thorson, G. (1950) Reproduction and larval ecology of marine bottom invertebrates. Biological Reviews, 25, 1-45.

Trewick, S.A. (2000) Molecular evidence for dispersal rather than vicariance as the origin of flightless insect species on the Chatham Islands, New Zealand. Journal of Biogeography, 27(5), 1189-1200.

Trewick, S.A., Paterson, A.M. \& Campbell, H.J. (2007) Hello New Zealand. Journal of Biogeography, 34, 1-6.

Trewick, S.A. \& Wallis, G.P. (2001) Bridging the "Beech Gap": New Zealand invertebrate phylogeography implicates Pleistocene glaciation and Pliocene isolation. Evolution, 55(11), 2170-2180.

Trewick, S.A., Wallis, G.P. \& Morgan-Richards, M. (2011) The invertebrate life of New Zealand: a phylogeographic approach. Insects, 2(3), 297-325.

van der Sman, J. (2007) Reproductive allocation and maternal investment in whelks. MSc thesis. Victoria University of Wellington, New Zealand. 
van der Sman, J., Phillips, N.E. \& Pfister, C.A. (2009) Relative effects of maternal and juvenile food availability for a marine snail. Ecology, 90(11), 3119-3125.

Veale, A.J. \& Lavery, S.D. (2011) Phylogeography of the snakeskin chiton Sypharochiton pelliserpentis (Mollusca: Polyplacophora) around New Zealand: are seasonal near-shore upwelling events a dynamic barrier to gene flow? Biological Journal of the Linnean Society, 104, 552-563.

Veale, A.J. \& Lavery, S.D. (2012) The population genetic structure of the waratah anemone (Actinia tenebrosa) around New Zealand. New Zealand Journal of Marine and Freshwater Research, 46(4), 523-536.

Waltari, E., Hijmans, R.J., Peterson, A.T., Nyári, Á.S., Perkins, S.L. \& Guralnick, R.P. (2007) Locating Pleistocene refugia: comparing phylogeographic and ecological niche model predictions. PLoS One, 2(7), e563.

Walton, K. \& Marshall, B.A. (in prep.) A revision of the living species of Cominella (Eucominia) from New Zealand (Gastropoda: Neogastropoda: Buccinidae).

Ward, R.D. (2000) Genetics in fisheries management. Hydrobiologica, 420, 191-201.

Warner, R.R. \& Cowen, R.K. (2002) Local retention of production in marine populations: evidence, mechanisms, and consequences. Bulletin of Marine Science, 70(1), 245-249.

Waters, J.M. (2008) Driven by the West Wind Drift? A synthesis of southern temperate marine biogeography, with new directions for dispersalism. Journal of Biogeography, 35(3), 417-427.

Waters, J.M. (2011) Competitive exclusion: phylogeography's 'elephant in the room'? Molecular Ecology, 20(21), 4388-4394.

Waters, J.M. \& Craw, D. (2006) Goodbye Gondwana? New Zealand biogeography, geology, and the problem of circularity. Systematic Biology, 55, 351-356. 
Waters, J.M. \& Roy, M.S. (2004) Phylogeography of a high-dispersal New Zealand sea-star: does upwelling block gene-flow? Molecular Ecology, 13(9), 27972806.

Waters, J.M., Fraser, C.I. \& Hewitt, G.M. (2013) Founder takes all: densitydependent processes structure biodiversity. Trends in Ecology and Evolution, 28(2), 78-85.

Weissel, J.K., Hayes, D.E. \& Herron, E.M. (1977) Plate tectonics synthesis: the displacements between Australia, New Zealand, and Antarctica since the Late Cretaceous. Marine Geology, 25, 231-277.

Wei, K., Wood, A.R. \& Gardner, J.P.A. (2013a) Population genetic variation in the New Zealand greenshell mussel: locus-dependent conflicting signals of weak structure and high gene flow balanced against pronounced structure and high self-recruitment. Marine biology, 160(4), 931-949.

Wei, K., Wood, A.R. \& Gardner, J.P.A. (2013b) Seascape genetics of the New Zealand greenshell mussel: sea surface temperature explains macrogeographic scale genetic variation. Marine Ecology Progress Series, 477, 107-121.

Wilcox, R.Z. (2015) A population genetic analysis of the New Zealand spotty (Notolabrus celidotus) using mitochondrial DNA and microsatellite DNA markers. MSc thesis. Victoria University of Wellington, New Zealand.

Will, M.C. and Gemmell, N.J. (2008) Genetic population structure of blackfoot paua. University of Otago report (GEN2007-01) to Ministry of Fisheries. (Unpublished report held by Ministry of Fisheries, Wellington).

Will, M.C., Hale, M.L., Schiel, D.R. \& Gemmell, N.J. (2011) Low to moderate levels of genetic differentiation detected across the distribution of the New Zealand abalone, Haliotis iris. Marine Biology, 158(6), 1417-1429. 
Will, M.C., McCowan, T. \& Gemmell, N.J. (2015) Broad-scale genetic patterns of New Zealand abalone, Haliotis iris, across a distribution spanning $13^{\circ}$ latitude and major oceanic water masses. Genetica, 143(4), 487-500.

Willan, R.C. (1974) Mollusca in Maori middens on Slipper Island. Tane, 20, 30-34.

Williams, S.T., Taylor, J.D. \& Glover, E.A. (2004) Molecular phylogeny of the Lucinoidea (Bivalvia): non-monophyly and separate acquisition of bacterial chemosymbiosis. Journal of Molluscan Studies, 70, 187-202.

Wilson, B. 1994. Australian marine shells. Prosobranch gastropods. 2 (neogastropods). Odyssey, Kallaroo, Australia.

Winnepenninckx, B.M.H., Reid, D. \& Backeljau, T. (1998) Performance of $18 \mathrm{~S}$ rRNA in littorinid phylogeny (Gastropoda: Caenogastropoda). Journal of Molecular Evolution, 47, 586-596.

Worthy, T.H. \& Holdaway, R.N. (1994) Quaternary fossil faunas from caves in Takaka Valley and on Takaka Hill, northwest Nelson, South Island, New Zealand. Journal of the Royal Society of New Zealand, 24(3), 297-391.

Worthy, T.H. \& Holdaway, R.N. (2002) The lost world of the moa. Prehistoric life of New Zealand. Indiana University Press, Bloomington, Indiana.

Wright, S. (1969) Evolution and the genetics of populations, the theory of allele frequencies. 2. Chicago University Press, Chicago, Illinois.

Young, M.W. (1929) Marine fauna of the Chatham Islands. Transactions and Proceedings of the New Zealand Institute, 60, 136-166. 


\section{Appendix}

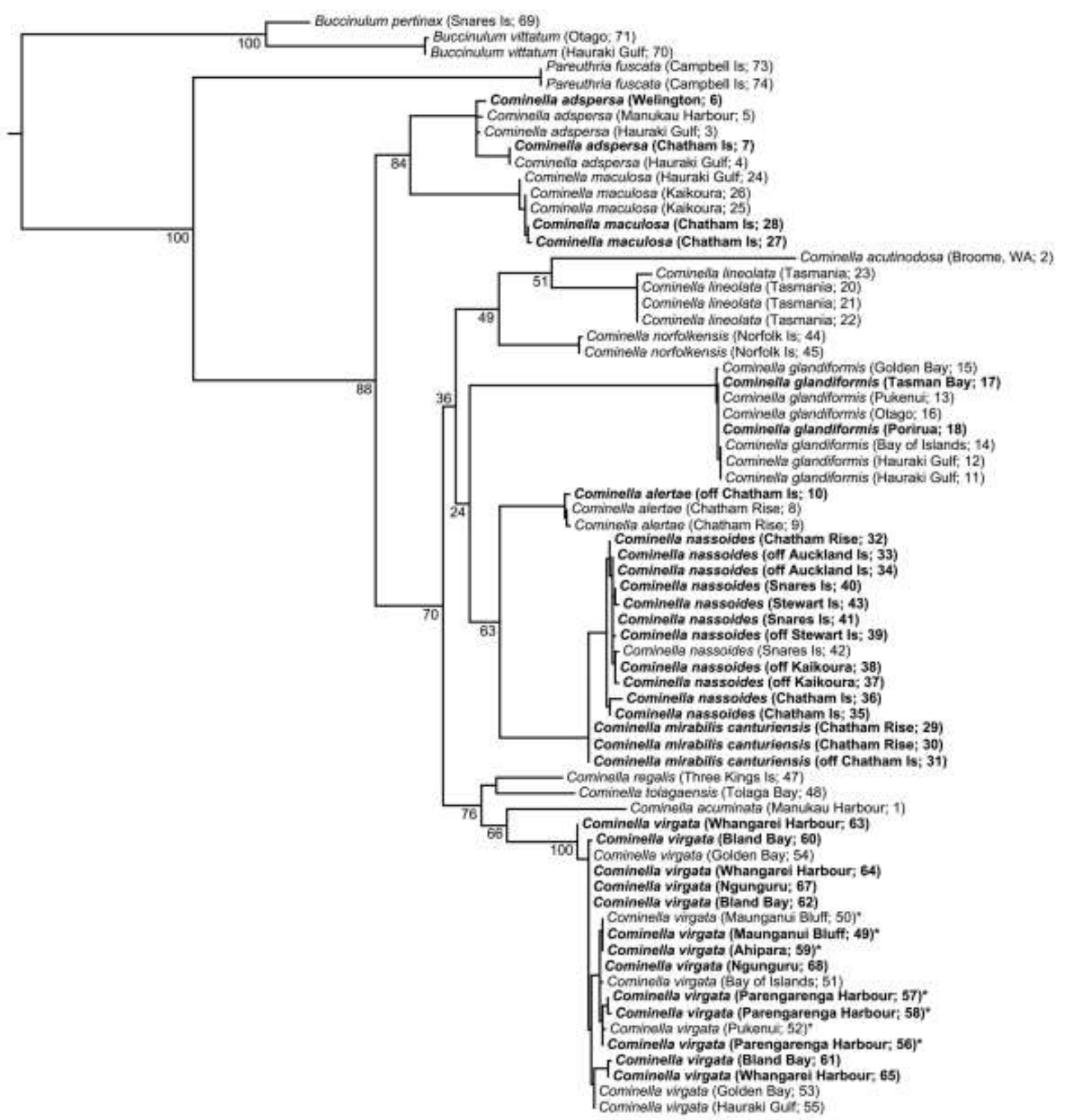

Supplementary Figure 1. Maximum likelihood phylogenetic tree of CO1 (528 bp) gene sequences. Node labels correspond to consensus bootstrap support percentage. Bold and italicized sequence labels correspond to sequences originating from this study. Others originated from Donald et al. (2015) via GenBank (Table 2.2). '*' denotes specimens of Cominella virgata of the 'brookesi' shell form. 


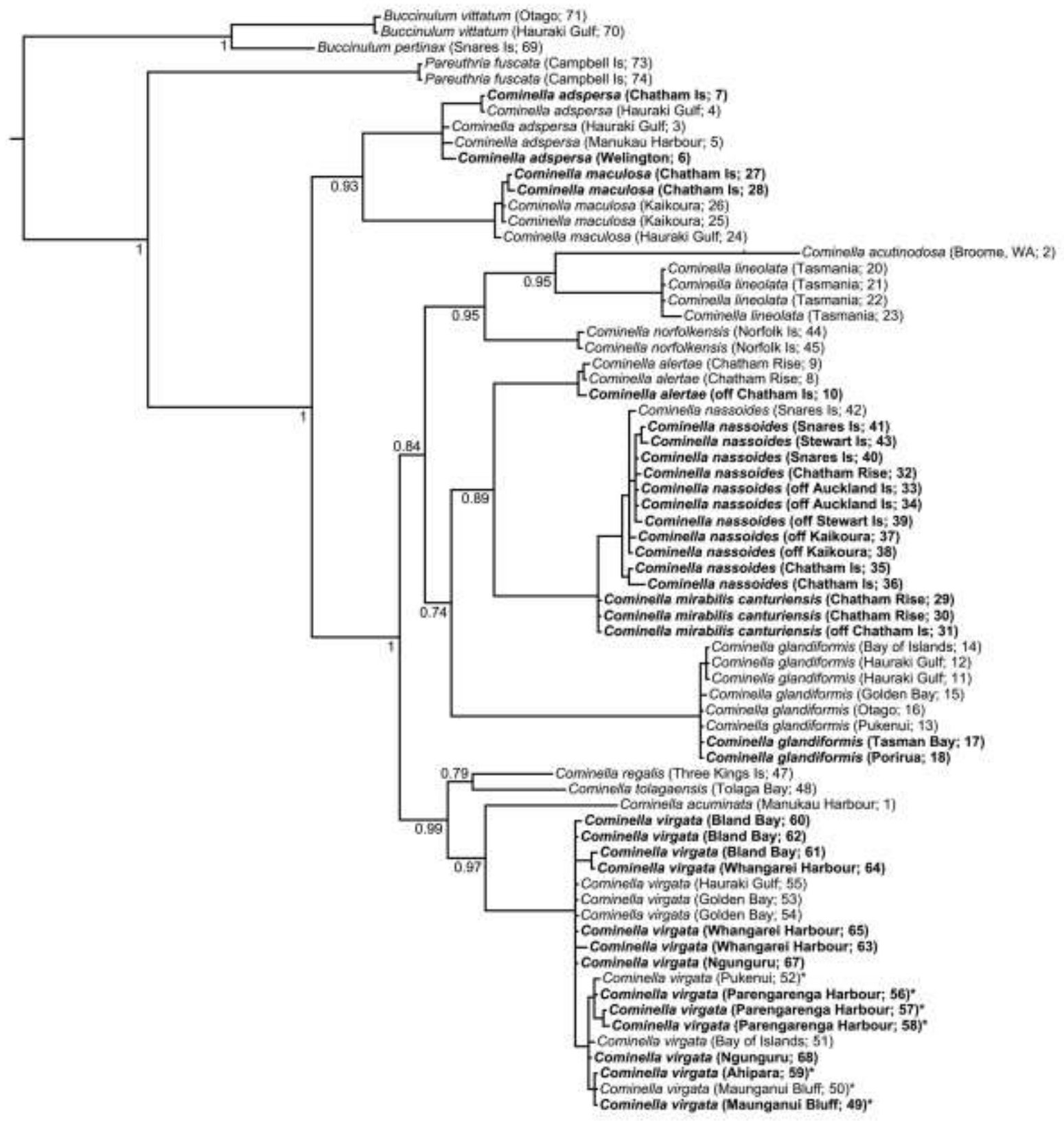

Supplementary Figure 2. Bayesian phylogenetic tree of CO1 (528 bp) gene sequences. Node labels correspond to posterior probability. Bold and italicized sequence labels correspond to sequences originating from this study. Others originated from Donald et al. (2015) via GenBank (Table 2.2). '*' denotes specimens of Cominella virgata of the 'brookesi' shell form. 


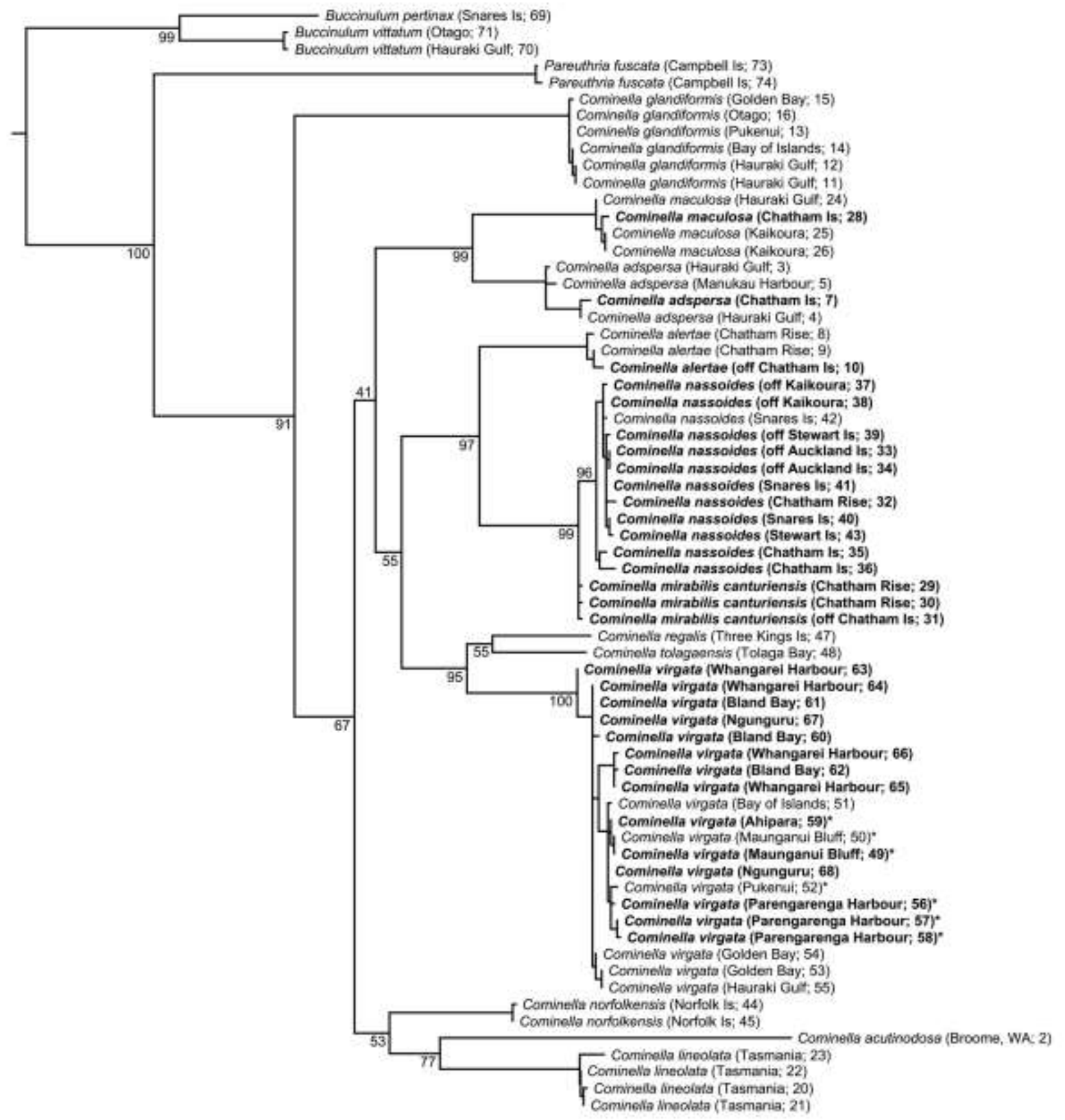

Supplementary Figure 3. Maximum likelihood tree of concatenated CO1 (528 bp), 16S (457 bp) and 18S (711 bp) gene sequences totalling 1,696 bp in length. Node labels correspond to consensus bootstrap support percentage. Bold and italicized sequence labels correspond to sequences originating from this study. Others originated from Donald et al. (2015) via GenBank (Table 2.2). '*' denotes specimens of Cominella virgata of the 'brookesi' shell form. 
Supplementary Table 1. Cominella maculosa additional statistics and neutrality tests.

\begin{tabular}{|c|c|c|c|c|c|c|c|}
\hline $\begin{array}{l}\text { Sampling } \\
\text { Site }\end{array}$ & $\begin{array}{l}\text { Tajima's D } \\
\text { (p-value) }\end{array}$ & $\begin{array}{l}\text { Fu's F-statistic } \\
\text { (p-value) }\end{array}$ & $\begin{array}{l}\text { SSD } \\
\text { (p-value) }\end{array}$ & $\begin{array}{l}\text { Rag } \\
\text { (p-value) }\end{array}$ & $\begin{array}{l}\text { Tau } \\
(95 \% \text { CI })\end{array}$ & $\begin{array}{l}\Theta_{0} \\
(95 \% \mathrm{CI})\end{array}$ & $\begin{array}{l}\Theta_{1} \\
(95 \% \mathrm{CI})\end{array}$ \\
\hline $\mathrm{BBO}$ & $-0.539(0.319)$ & $0.851(0.693)$ & $0.348(<0.000)$ & $0.437(0.900)$ & $0.00(0.00-0.582)$ & $0.00(0.00-0.004)$ & 99999(99869-99999) \\
\hline WCP & $-0.728(0.254)$ & $-0.349(0.152)$ & $<0.000(0.300)$ & $0.532(0.650)$ & $0.217(0.184-0.797)$ & $0.00(0.00-0.037)$ & $0.369(0.00-99999)$ \\
\hline $\mathrm{CHM}$ & $-1.164(0.155)$ & $-0.879(0.064)$ & $<0.000(0.350)$ & $0.65(0.75)$ & $3.00(0.559-22.016)$ & $0.00(0.00-0.00)$ & $0.118(0.00-99999)$ \\
\hline $\mathrm{CIO}$ & - & - & - & - & - & - & - \\
\hline CIW & $-0.612(0.377)$ & $0.172(0.353)$ & $0.022(0.800)$ & $0.250(0.900)$ & $0.764(0.00-1.807)$ & $0.00(0.000-0.004)$ & 99999(349-99999) \\
\hline KKM & - & - & - & - & - & - & - \\
\hline KTM & - & - & - & - & - & - & - \\
\hline MBM & $-1.164(0.136)$ & $-0.879(0.097)$ & $<0.000(0.300)$ & $0.65(0.75)$ & $3.00(0.309-3.00)$ & $0.00(0.00-0.030)$ & $0.118(0.00-0.521)$ \\
\hline PBM & $-1.164(0.056)$ & $-0.879(0.089)$ & $<0.000(0.500)$ & $0.650(0.700)$ & $3.00(0.309-3.00)$ & $0.00(0.00-0.030)$ & $0.118(0.00-99999)$ \\
\hline PRM & $0(1)$ & $0(-)$ & - & - & - & - & - \\
\hline WCM & $-1.513(0.056)$ & $-14.863(0.011)$ & $0.001(0.350)$ & $0.413(0.75)$ & $3.00(0.689-3.00)$ & $0.00(0.00-0.060)$ & $0.255(0.000-99999)$ \\
\hline WPH & - & - & - & - & - & - & - \\
\hline WMA & - & - & - & - & - & - & - \\
\hline $\mathrm{AAB}$ & $-1.279(0.077)$ & $-1.936(0.034)$ & $0.004(0.45)$ & $0.184(0.300)$ & $0.477(0.123-1.258)$ & $0.00(0.00-0.016)$ & 99999(14.684-99999) \\
\hline $\mathrm{ARB}$ & $-1.679(0.02)$ & $-1.795(0.039)$ & $<0.000(0.750)$ & $0.232(0.500)$ & $3.00(0.00-128.00)$ & $0.00(0.00-1.020)$ & $0.479(0.00-99999)$ \\
\hline ASB & $-1.441(0.071)$ & $-2.135(0.009)$ & $0.002(0.300)$ & $0.299(0.750)$ & $3.00(0.550-3.500)$ & $0.00(0.00-0.217)$ & $0.400(0.00-99999)$ \\
\hline TNP & $0.180(0.750)$ & $0.637(0.461)$ & $0.254(0.200)$ & $0.273(0.150)$ & $2.982(0.00-87.982)$ & $0.900(0.00-7.140)$ & $3.600(0.52-99999)$ \\
\hline TMA & - & - & - & - & - & - & - \\
\hline BMM & $0.124(0.592)$ & $-0.815(0.200)$ & $0.043(0.45)$ & $0.133(0.500)$ & $3.047(0.00-4.266)$ & $0.00(0.00-0.192)$ & $4.883(2.299-99999)$ \\
\hline BMA & $-0.857(0.217)$ & $-2.124(0.069)$ & $0.026(0.050)$ & $0.199(<0.000)$ & $1.156(0.338-2.363)$ & $0.002(0.00-0.156)$ & 99999(1.931-99999) \\
\hline $\mathrm{BOM}$ & $0.430(0.726)$ & $0.032(0.518)$ & $0.031(0.100)$ & $0.110(0.200)$ & $3.55(0.00-10.625)$ & $0.00(0.00-1.825)$ & $5.723(0.414-99999)$ \\
\hline GTA & $1.041(0.856)$ & $1.838(0.855)$ & $0.135(0.050)$ & $0.530(0.150)$ & $4.086(0.00-128.00)$ & $0.002(0.00-1.040)$ & $0.667(0.00-99999)$ \\
\hline GTT & $-1.889(0.003)$ & $0.587(0.424)$ & $0.007(0.050)$ & $0.876(0.900)$ & $3.00(0.816-3.00)$ & $0.00(0.00-0.00)$ & $0.038(0.00-99999)$ \\
\hline WCS & $2.253(0.991)$ & $3.929(0.944)$ & $0.102(0.200)$ & $0.123(0.100)$ & $8.826(0.00-97.826)$ & $0.002(0.00-14.538)$ & $5.823(4.74-99999)$ \\
\hline NEL & $-0.334(0.416)$ & $-0.019(0.515)$ & $0.452(<0.000)$ & $0.119(1.00)$ & $0.00(0.00-0.314)$ & $0.00(0.00-0.016)$ & 99999(99869-99999) \\
\hline WMP & $-0.562(0.238)$ & $-0.055(0.237)$ & $0.332(0.200)$ & $0.402(0.100)$ & $2.930(0.00-87.93)$ & $0.900(0.00-4.500)$ & $3.600(2.731-99999)$ \\
\hline AMB & $0.074(0.571)$ & $0.361(0.559)$ & $0.023(0.400)$ & $0.086(0.600)$ & $2.293(0.689-4.051)$ & $0.002(0.00-1.446)$ & $7.020(2.313-99999)$ \\
\hline GMA & $-1.037(0.185)$ & $1.132(0.761)$ & $0.033(0.050)$ & $0.314(0.700)$ & $3.00(0.344-3.500)$ & $0.00(0.00-0.217)$ & $0.460(0.00-99999)$ \\
\hline GPA & $-1.159(0.151)$ & $-1.028(0.077)$ & $<0.000(0.100)$ & $0.701(0.850)$ & $2.992(0.621-2.992)$ & $0.056(0.00-0.816)$ & $0.113(0.00-99999)$ \\
\hline GPB & $-1.884(0.004)$ & $0.795(0.479)$ & $0.010(0.050)$ & $0.854(0.950)$ & $3.00(3.00-3.00)$ & $0.00(0.00-0.00)$ & $0.046(0.00-0.425)$ \\
\hline GWB & $1.918(0.978)$ & $4.688(0.971)$ & $0.194(0.050)$ & $0.299(<0.000)$ & $8.424(0.00-63.424)$ & $0.002(0.00-5.409)$ & $3.153(2.374-99999)$ \\
\hline
\end{tabular}


Supplementary Table 2. Cominella virgata additional statistics and neutrality tests.

\begin{tabular}{|c|c|c|c|c|c|c|c|}
\hline $\begin{array}{l}\text { Sampling } \\
\text { Site }\end{array}$ & $\begin{array}{l}\text { Tajima's D } \\
\text { (p-value) }\end{array}$ & $\begin{array}{l}\text { Fu's F-statistic } \\
\text { (p-value) }\end{array}$ & $\begin{array}{l}\text { SSD } \\
\text { (p-value) }\end{array}$ & $\begin{array}{l}\text { Rag } \\
\text { (p-value) }\end{array}$ & $\begin{array}{l}\text { Tau } \\
(95 \% \mathrm{CI})\end{array}$ & $\begin{array}{l}\Theta_{0} \\
(95 \% \mathrm{CI})\end{array}$ & $\begin{array}{l}\Theta_{1} \\
(95 \% \mathrm{CI})\end{array}$ \\
\hline AHV & $-1.164(0.164)$ & $-0.879(0.084)$ & $<0.00(0.15)$ & $0.65(0.85)$ & $3.00(0.45-3.00)$ & $0.00(0.00-0.005)$ & $0.118(0.00-99999)$ \\
\hline BBV & $1.870(0.979)$ & $4.187(0.965)$ & $0.14(<0.00)$ & $0.16(0.30)$ & $12.22(0.50-65.21)$ & $0.00(0.00-1.15)$ & $3.91(0.79-99999)$ \\
\hline KTV & - & - & - & - & - & - & - \\
\hline MAV & - & - & - & - & - & - & - \\
\hline MGV & $2.236(0.993)$ & $5.629(0.987)$ & $0.10(0.05)$ & $0.19(<0.00)$ & $15.75(0.64-87.42)$ & $0.00(0.00-14.57)$ & $14.38(7.61-99999)$ \\
\hline $\mathrm{NGV}$ & $-1.418(0.081)$ & $-1.083(0.300)$ & $0.04(0.45)$ & $0.08(0.55)$ & $9.84(0.34-95.84)$ & $0.00(0.0-1.49)$ & $2.27(0.32-99999)$ \\
\hline PAV & $-0.946(0.187)$ & $-1.183(0.163)$ & $0.01(0.40)$ & $0.09(0.55)$ & $0.88(0.17-1.59)$ & $0.00(0.0-0.05)$ & 99999 (4.26-99999) \\
\hline PBV & - & - & - & - & - & - & - \\
\hline PRV & - & - & - & - & - & - & - \\
\hline WPB & - & - & - & - & - & - & - \\
\hline WPH & $1.193(0.899)$ & $5.917(0.980)$ & $0.12(0.15)$ & $0.89(0.40)$ & $3.00(0.00-3.50)$ & $0.00(0.00-0.23)$ & $0.46(0.00-99999)$ \\
\hline WMP & $0.104(0.586)$ & $4.489(0.970)$ & $0.08(<0.00)$ & $0.56(0.75)$ & $3.00(0.49-3.50)$ & $0.00(0.00-0.22)$ & $0.24(0.00-99999)$ \\
\hline AMB & - & - & - & - & - & - & - \\
\hline $\mathrm{AAB}$ & $2.019(0.983)$ & $4.873(0.965)$ & $0.17(0.10)$ & $0.20(<0.00)$ & $10.61(0.00-63.61)$ & $0.00(0.00-3.08)$ & $5.44(4.35-99999)$ \\
\hline ARB & $-1.494(0.076)$ & $-0.878(0.167)$ & $0.04(0.15)$ & $0.75(0.50)$ & $3.00(0.00-3.00)$ & $0.00(0.00-0.00)$ & $0.13(0.00-99999)$ \\
\hline ASB & $-1.884(0.004)^{*}$ & $-3.974(<0.000)^{*}$ & $<0.00(0.65)$ & $0.23(0.65)$ & $0.67(0.00-0.70)$ & $0.00(0.00-0.02)$ & 99999 (12.98-99999) \\
\hline BMM & $-0.676(0.287)$ & $3.211(0.916)$ & $0.05(0.05)$ & $0.73(0.65)$ & $3.00(0.45-3.50)$ & $0.00(0.00-0.91)$ & $0.13(0.00-99999)$ \\
\hline BMA & $-0.197(0.503)$ & $1.368(0.749)$ & $0.16(0.10)$ & $0.32(0.05)$ & $6.42(0.00-12.56)$ & $0.00(0.00-0.097)$ & $3.80(2.06-99999)$ \\
\hline BOM & $-1.571(0.019)^{*}$ & $-1.532(0.025)$ & $<0.00(0.15)$ & $0.74(0.80)$ & $3.00(0.96-3.00)$ & $0.00(0.00-0.00)$ & $0.08(0.00-99999)$ \\
\hline GTA & $2.178(0.982)$ & $3.790(0.940)$ & $0.06(0.00)$ & $0.15(<0.00)$ & $7.59(4.16-12.97)$ & $0.00(0.00-2.51)$ & $8.90(6.44-108.90)$ \\
\hline NEL & $-1.50738(0.052)$ & $-0.39563(0.176)$ & $<0.00(<0.00)$ & $0.88(0.90)$ & $3.00(3.00-3.00)$ & $0.00(0.00-0.00)$ & $0.04(0.00-0.13)$ \\
\hline GMP & - & - & - & - & - & - & - \\
\hline
\end{tabular}


Supplementary Table 3. Cominella maculosa sample site pairwise differences calculated using genetic distance (below) and associated pvalues (above).

\begin{tabular}{|c|c|c|c|c|c|c|c|c|c|c|c|c|c|c|c|c|c|c|c|c|c|}
\hline & BBO & WCP & CHM & CIO & CIW & KKM & KTM & MBM & PBM & PRM & WCM & WPH & WMA & $\mathrm{AAB}$ & ARB & ASB & TNP & TMA & BMM & BMA & BOM \\
\hline BBO & & $<0.01$ & $<0.01$ & $<0.01$ & $<0.01$ & $<0.01$ & $<0.01$ & $<0.01$ & $<0.01$ & $<0.01$ & $<0.01$ & $<0.01$ & $<0.01$ & $<0.01$ & $<0.01$ & $<0.01$ & $<0.01$ & $<0.01$ & 0.01 & $<0.01$ & 0.01 \\
\hline $\mathrm{WCP}$ & 0.85 & & 0.33 & 0.01 & $<0.01$ & 0.47 & 0.56 & 0.32 & 0.34 & 0.46 & 0.20 & 0.60 & 0.48 & $<0.01$ & $<0.01$ & $<0.01$ & 0.02 & $<0.01$ & $<0.01$ & $<0.01$ & $<0.01$ \\
\hline CHM & 0.83 & 0.02 & & 0.02 & $<0,01$ & 0.99 & 0.99 & 0.99 & 0.99 & 0.99 & 0.99 & 0.45 & 0.99 & $<0.01$ & $<0.01$ & $<0.01$ & 0.14 & $<0.01$ & $<0.01$ & $<0.01$ & $<0.01$ \\
\hline $\mathrm{CIO}$ & 0.70 & 0.88 & 0.91 & & 0.99 & $<0.01$ & $<0.01$ & $<0.01$ & $<0.01$ & 0.01 & 0.02 & $<0.01$ & $<0.01$ & 0.01 & $<0,01$ & 0.01 & $<0,01$ & 0.02 & 0.01 & $<0.01$ & $<0.01$ \\
\hline CIW & 0.73 & 0.85 & 0.87 & 0.00 & & $<0.01$ & $<0.01$ & $<0.01$ & $<0.01$ & $<0.01$ & $<0.01$ & $<0.01$ & $<0.01$ & $<0.01$ & $<0.01$ & $<0.01$ & $<0.01$ & $<0.01$ & 0.01 & $<0.01$ & $<0.01$ \\
\hline KKM & 0.85 & 0.02 & 0.00 & 1.00 & 0.94 & & 0.99 & 0.99 & 0.99 & 0.99 & 0.99 & 0.99 & 0.99 & $<0.01$ & $<0.01$ & $<0.01$ & 0.16 & $<0.01$ & $<0.01$ & $<0.01$ & $<0.01$ \\
\hline KTM & 0.85 & 0.02 & 0.00 & 1.00 & 0.94 & 0.00 & & 0.99 & 0.99 & 0.99 & 0.50 & 0.99 & 0.99 & $<0.01$ & $<0.01$ & $<0.01$ & 0.18 & $<0.01$ & $<0.01$ & $<0.01$ & $<0.01$ \\
\hline MBM & 0.83 & 0.02 & 0.00 & 0.91 & 0.87 & 0.00 & 0.00 & & 0.99 & 0.99 & 0.99 & 0.53 & 0.99 & $<0.01$ & $<0.01$ & $<0.01$ & 0.06 & $<0.01$ & $<0.01$ & $<0.01$ & $<0.01$ \\
\hline PBM & 0.83 & 0.02 & 0.00 & 0.91 & 0.87 & 0.00 & 0.00 & 0.00 & & 0.99 & 0.99 & 0.44 & 0.99 & $<0.01$ & $<0.01$ & $<0.01$ & 0.11 & $<0.01$ & $<0.01$ & $<0.01$ & $<0.01$ \\
\hline PRM & 0.85 & 0.02 & 0.00 & 1.00 & 0.94 & 0.00 & 0.00 & 0.00 & 0.00 & & 0.99 & 0.99 & 0.99 & $<0.01$ & $<0.01$ & $<0.01$ & 0.10 & $<0.01$ & $<0.01$ & $<0.01$ & $<0.01$ \\
\hline WCM & 0.82 & 0.02 & 0.00 & 0.83 & 0.81 & 0.00 & 0.00 & 0.00 & 0.00 & 0.00 & & 0.23 & 0.99 & $<0.01$ & $<0.01$ & $<0.01$ & 0.05 & $<0.01$ & $<0.01$ & $<0.01$ & $<0.01$ \\
\hline WPH & 0.85 & 0.03 & 0.00 & 1.00 & 0.94 & 0.00 & 0.00 & 0.00 & 0.00 & 0.00 & 0.00 & & 0.99 & $<0.01$ & $<0.01$ & $<0.01$ & 0.04 & $<0.01$ & $<0.01$ & $<0.01$ & $<0.01$ \\
\hline WMA & 0.85 & 0.02 & 0.00 & 1.00 & 0.94 & 0.00 & 0.00 & 0.00 & 0.00 & 0.00 & 0.00 & 0.00 & & $<0.01$ & $<0.01$ & $<0.01$ & 0.14 & $<0.01$ & $<0.01$ & $<0.01$ & $<0.01$ \\
\hline AAB & 0.58 & 0.92 & 0.92 & 0.91 & 0.91 & 0.93 & 0.93 & 0.92 & 0.92 & 0.93 & 0.91 & 0.93 & 0.93 & & 0.26 & 0.10 & $<0.01$ & $<0.01$ & $<0.01$ & 0.02 & $<0.01$ \\
\hline ARB & 0.61 & 0.92 & 0.92 & 0.91 & 0.90 & 0.93 & 0.93 & 0.92 & 0.91 & 0.93 & 0.90 & 0.93 & 0.93 & 0.02 & & 0.48 & $<0.01$ & $<0.01$ & 0.01 & 0.14 & $<0.01$ \\
\hline ASB & 0.60 & 0.92 & 0.92 & 0.91 & 0.91 & 0.94 & 0.93 & 0.92 & 0.92 & 0.94 & 0.91 & 0.94 & 0.94 & 0.03 & 0.00 & & $<0.01$ & $<0.01$ & $<0.01$ & 0.08 & $<0.01$ \\
\hline TNP & 0.84 & 0.10 & 0.09 & 0.78 & 0.78 & 0.10 & 0.10 & 0.09 & 0.09 & 0.10 & 0.08 & 0.10 & 0.10 & 0.90 & 0.90 & 0.90 & & $<0.01$ & $<0.01$ & $<0.01$ & $<0.01$ \\
\hline TMA & 0.87 & 0.99 & 0.99 & 1.00 & 0.99 & 1.00 & 1.00 & 0.99 & 0.99 & 1.00 & 0.98 & 1.00 & 1.00 & 0.92 & 0.92 & 0.93 & 0.97 & & $<0.01$ & $<0.01$ & $<0.01$ \\
\hline BMM & 0.17 & 0.85 & 0.84 & 0.70 & 0.74 & 0.85 & 0.85 & 0.84 & 0.83 & 0.85 & 0.82 & 0.86 & 0.85 & 0.23 & 0.29 & 0.28 & 0.84 & 0.85 & & $<0.01$ & 0.35 \\
\hline BMA & 0.54 & 0.85 & 0.84 & 0.81 & 0.82 & 0.85 & 0.85 & 0.84 & 0.83 & 0.85 & 0.83 & 0.85 & 0.85 & 0.06 & 0.03 & 0.04 & 0.84 & 0.83 & 0.24 & & $<0.01$ \\
\hline BOM & 0.17 & 0.73 & 0.70 & 0.64 & 0.67 & 0.71 & 0.71 & 0.70 & 0.70 & 0.71 & 0.70 & 0.71 & 0.71 & 0.18 & 0.21 & 0.21 & 0.73 & 0.68 & 0.02 & 0.22 & \\
\hline GTA & 0.66 & 0.87 & 0.86 & 0.82 & 0.83 & 0.86 & 0.86 & 0.86 & 0.86 & 0.86 & 0.85 & 0.87 & 0.86 & 0.60 & 0.58 & 0.59 & 0.86 & 0.86 & 0.54 & 0.54 & 0.40 \\
\hline GTT & 0.85 & 0.96 & 0.97 & 0.96 & 0.96 & 0.97 & 0.97 & 0.97 & 0.97 & 0.97 & 0.96 & 0.97 & 0.97 & 0.89 & 0.89 & 0.90 & 0.95 & 0.97 & 0.83 & 0.83 & 0.36 \\
\hline WCS & 0.34 & 0.65 & 0.62 & 0.48 & 0.53 & 0.62 & 0.62 & 0.62 & 0.62 & 0.62 & 0.62 & 0.63 & 0.62 & 0.40 & 0.41 & 0.40 & 0.66 & 0.66 & 0.31 & 0.40 & 0.34 \\
\hline NEL & 0.58 & 0.16 & 0.13 & 0.29 & 0.37 & 0.14 & 0.14 & 0.13 & 0.12 & 0.14 & 0.13 & 0.14 & 0.14 & 0.60 & 0.59 & 0.58 & 0.17 & 0.81 & 0.52 & 0.54 & 0.51 \\
\hline WMP & 0.82 & 0.05 & 0.04 & 0.84 & 0.81 & 0.06 & 0.06 & 0.04 & 0.04 & 0.06 & -0.03 & 0.06 & 0.06 & 0.91 & 0.90 & 0.91 & 0.10 & 0.99 & 0.82 & 0.82 & 0.69 \\
\hline AMB & 0.42 & 0.85 & 0.83 & 0.70 & 0.74 & 0.85 & 0.85 & 0.83 & 0.83 & 0.85 & 0.82 & 0.85 & 0.85 & 0.20 & 0.19 & 0.13 & 0.84 & 0.84 & 0.18 & 0.13 & 0.20 \\
\hline GMA & 0.68 & 0.87 & 0.86 & 0.81 & 0.82 & 0.87 & 0.87 & 0.86 & 0.86 & 0.87 & 0.85 & 0.87 & 0.87 & 0.72 & 0.71 & 0.71 & 0.86 & 0.87 & 0.63 & 0.67 & 0.56 \\
\hline GPA & 0.78 & 0.98 & 0.98 & 0.99 & 0.98 & 0.99 & 0.99 & 0.98 & 0.98 & 0.99 & 0.97 & 0.99 & 0.99 & 0.94 & 0.94 & 0.95 & 0.96 & 0.99 & 0.86 & 0.88 & 0.73 \\
\hline GPB & 0.72 & 0.95 & 0.95 & 0.95 & 0.94 & 0.96 & 0.96 & 0.95 & 0.95 & 0.96 & 0.95 & 0.96 & 0.96 & 0.90 & 0.91 & 0.91 & 0.94 & 0.98 & $\begin{array}{ll}0.81 \\
\end{array}$ & 0.85 & 0.70 \\
\hline GWB & 0.33 & 0.67 & 0.64 & 0.51 & 0.56 & 0.65 & 0.65 & 0.64 & 0.63 & 0.65 & 0.64 & 0.65 & 0.65 & 0.43 & 0.43 & 0.42 & 0.68 & 0.69 & 0.32 & 0.42 & 0.34 \\
\hline
\end{tabular}


Supplementary Table 3 continued...

\begin{tabular}{|c|c|c|c|c|c|c|c|c|c|c|}
\hline & GTA & GTT & WCS & NEL & WMP & AMB & GMA & GPA & GPB & GWB \\
\hline BBO & $<0.01$ & $<0.01$ & $<0.01$ & $<0.01$ & $<0.01$ & $<0.01$ & $<0.01$ & $<0.01$ & $<0.01$ & $<0.01$ \\
\hline WCP & $<0.01$ & $<0.01$ & $<0.01$ & $<0.01$ & 0.20 & $<0.01$ & $<0.01$ & $<0.01$ & $<0.01$ & $<0.01$ \\
\hline CHM & $<0.01$ & $<0.01$ & $<0.01$ & 0.01 & 0.24 & $<0.01$ & $<0.01$ & $<0.01$ & $<0.01$ & $<0.01$ \\
\hline CIO & $<0.01$ & $<0.01$ & $<0.01$ & 0.05 & 0.03 & 0.04 & 0.01 & $<0.01$ & $<0.01$ & $<0.01$ \\
\hline CIW & $<0.01$ & $<0.01$ & $<0.01$ & 0.02 & $<0.01$ & 0.01 & $<0.01$ & $<0.01$ & $<0.01$ & $<0.01$ \\
\hline KKM & $<0.01$ & $<0.01$ & $<0.01$ & 0.01 & 0.24 & $<0.01$ & $<0.01$ & $<0.01$ & $<0.01$ & $<0.01$ \\
\hline KTM & $<0.01$ & $<0.01$ & $<0.01$ & $<0.01$ & 0.24 & $<0.01$ & $<0.01$ & $<0.01$ & $<0.01$ & $<0.01$ \\
\hline MBM & $<0.01$ & $<0.01$ & $<0.01$ & $<0.01$ & 0.28 & $<0.01$ & $<0.01$ & $<0.01$ & $<0.01$ & $<0.01$ \\
\hline PBM & $<0.01$ & $<0.01$ & $<0.01$ & $<0.01$ & 0.27 & $<0.01$ & $<0.01$ & $<0.01$ & $<0.01$ & $<0.01$ \\
\hline PRM & $<0.01$ & $<0.01$ & $<0.01$ & 0.02 & 0.17 & $\begin{array}{l}<0.01 \\
\end{array}$ & $<0.01$ & $<0.01$ & $<0.01$ & $<0.01$ \\
\hline WCM & $<0.01$ & $<0.01$ & $<0.01$ & 0.01 & 0.19 & $<0.01$ & $<0.01$ & $<0.01$ & $<0.01$ & $<0.01$ \\
\hline WPH & $<0.01$ & $<0.01$ & $<0.01$ & $<0.01$ & 0.20 & $<0.01$ & $<0.01$ & $<0.01$ & $<0.01$ & $<0.01$ \\
\hline WMA & $<0.01$ & $<0.01$ & $<0.01$ & 0.01 & 0.26 & $<0.01$ & $<0.01$ & $<0.01$ & $<0.01$ & $<0.01$ \\
\hline AAB & $<0.01$ & $<0.01$ & $<0.01$ & $<0.01$ & $<0.01$ & $<0.01$ & $<0.01$ & $<0.01$ & $<0.01$ & $<0.01$ \\
\hline ARB & $<0.01$ & $<0.01$ & $<0.01$ & $<0.01$ & $<0.01$ & 0.01 & $<0.01$ & $<0.01$ & $<0.01$ & $<0.01$ \\
\hline ASB & $<0.01$ & $<0.01$ & $<0.01$ & $<0.01$ & $<0.01$ & 0.06 & $<0.01$ & $<0.01$ & $<0.01$ & $<0.01$ \\
\hline TNP & $<0.01$ & $<0.01$ & $<0.01$ & $<0.01$ & 0.02 & $<0.01$ & $<0.01$ & $<0.01$ & $<0.01$ & $<0.01$ \\
\hline TMA & $<0.01$ & $<0.01$ & $<0.01$ & $<0.01$ & $<0.01$ & $<0.01$ & $<0.01$ & $<0.01$ & $<0.01$ & $<0.01$ \\
\hline BMM & $<0.01$ & $<0.01$ & $<0.01$ & $<0.01$ & $<0.01$ & 0.01 & $<0.01$ & $<0.01$ & $<0.01$ & 0.01 \\
\hline BMA & $<0.01$ & $<0.01$ & $<0.01$ & $<0.01$ & $<0.01$ & $<0.01$ & $<0.01$ & $<0.01$ & $<0.01$ & $<0.01$ \\
\hline BOM & $<0.01$ & $<0.01$ & $<0.01$ & $<0.01$ & $<0.01$ & $<0.01$ & $<0.01$ & $<0.01$ & $<0.01$ & $<0.01$ \\
\hline GTA & & $<0.01$ & $<0.01$ & $<0.01$ & $<0.01$ & $<0.01$ & $<0.01$ & $<0.01$ & $<0.01$ & $<0.01$ \\
\hline GTT & 0.78 & & $<0.01$ & $<0.01$ & $<0.01$ & $<0.01$ & 0.14 & $<0.01$ & $<0.01$ & $<0.01$ \\
\hline WCS & 0.44 & 0.33 & & $<0.01$ & $<0.01$ & $<0.01$ & $<0.01$ & $<0.01$ & $<0.01$ & 0.61 \\
\hline NEL & 0.66 & 0.81 & 0.48 & & 0.02 & $<0.01$ & $<0.01$ & $<0.01$ & $<0.01$ & $<0.01$ \\
\hline WMP & 0.85 & 0.96 & 0.61 & 0.13 & & $<0.01$ & $<0.01$ & $<0.01$ & $<0.01$ & $<0.01$ \\
\hline AMB & 0.52 & 0.82 & 0.33 & 0.51 & 0.82 & & $<0.01$ & $<0.01$ & $<0.01$ & $<0.01$ \\
\hline GMA & 0.63 & 0.03 & 0.18 & 0.70 & 0.85 & 0.62 & & $<0.01$ & $<0.01$ & 0.07 \\
\hline GPA & 0.89 & 0.97 & 0.54 & 0.80 & 0.98 & 0.88 & 0.88 & & 0.99 & $<0.01$ \\
\hline GPB & 0.87 & 0.96 & 0.50 & 0.77 & 0.95 & 0.83 & 0.86 & 0.00 & & $<0.01$ \\
\hline GWB & 0.46 & 0.39 & 0.00 & 0.49 & 0.63 & 0.34 & 0.22 & 0.53 & 0.49 & \\
\hline
\end{tabular}


Supplementary Table 4. Cominella maculosa sample site pairwise differences calculated using haplotype frequencies (below) and associated pvalues (above).

\begin{tabular}{|c|c|c|c|c|c|c|c|c|c|c|c|c|c|c|c|c|c|c|c|c|c|}
\hline & $\mathrm{BBO}$ & WCP & CHM & CIO & CIW & KKM & KTM & MBM & PBM & PRM & WCM & WPH & WMA & $\mathrm{AAB}$ & ARB & ASB & TNP & TMA & BMM & BMA & BOM \\
\hline BBO & & $<0.01$ & $<0.01$ & 0.01 & $<0.01$ & $<0.01$ & $<0.01$ & $<0.01$ & $<0.01$ & $<0.01$ & $<0.01$ & $<0.01$ & $<0.01$ & $<0.01$ & $<0.01$ & $<0.01$ & $<0.01$ & $<0.01$ & $<0.01$ & $<0.01$ & 0.05 \\
\hline WCP & 0.74 & & 0.50 & $<0.01$ & $<0.01$ & 0.59 & 0.51 & 0.46 & 0.41 & 0.56 & 0.61 & 0.52 & 0.51 & $<0.01$ & $<0.01$ & $<0.01$ & 0.10 & $<0.01$ & $<0.01$ & $<0.01$ & $<0.01$ \\
\hline CHM & 0.75 & 0.00 & & $<0.01$ & $<0.01$ & 0.99 & 0.99 & 0.99 & 0.99 & 0.99 & 0.99 & 0.51 & 0.99 & $<0.01$ & $<0.01$ & $<0.01$ & 0.13 & $<0.01$ & $<0.01$ & $<0.01$ & $<0.01$ \\
\hline $\mathrm{CIO}$ & 0.59 & 0.87 & 0.91 & & 0.99 & $<0.01$ & $<0.01$ & $<0.01$ & 0.02 & $<0.01$ & $<0.01$ & $<0.01$ & 0.01 & $<0,01$ & 0.02 & $<0.01$ & $<0.01$ & 0.01 & 0.02 & $<0.01$ & $<0.01$ \\
\hline CIW & 0.51 & 0.80 & 0.83 & 0.00 & & $<0.01$ & $<0.01$ & $<0.01$ & $<0.01$ & $<0.01$ & $<0.01$ & $<0.01$ & $<0.01$ & $<0.01$ & $<0.01$ & $<0.01$ & $<0.01$ & $<0.01$ & 0.02 & $<0.01$ & $<0.01$ \\
\hline KKM & 0.82 & 0.02 & 0.00 & 1.00 & 0.92 & & 0.99 & 0.99 & 0.99 & 0.99 & 0.58 & 0.99 & 0.99 & $<0.01$ & $<0.01$ & $<0.01$ & 0.15 & $<0.01$ & $<0.01$ & $<0.01$ & $<0.01$ \\
\hline KTM & 0.82 & 0.02 & 0.00 & 1.00 & 0.92 & 0.00 & & 0.99 & 0.99 & 0.99 & 0.50 & 0.99 & 0.99 & $<0.01$ & $<0.01$ & $<0.01$ & 0.11 & $<0.01$ & $<0.01$ & $<0.01$ & $<0.01$ \\
\hline MBM & 0.75 & 0.00 & 0.00 & 0.91 & 0.83 & 0.00 & 0.00 & & 0.99 & 0.99 & 0.99 & 0.47 & 0.99 & $<0.01$ & $<0.01$ & $<0.01$ & 0.14 & $<0.01$ & $<0.01$ & $<0.01$ & $<0.01$ \\
\hline PBM & 0.75 & 0.00 & 0.00 & 0.91 & 0.83 & 0.00 & 0.00 & 0.00 & & 0.99 & 0.99 & 0.41 & 0.99 & $<0.01$ & $<0.01$ & $<0.01$ & 0.17 & $<0.01$ & $<0.01$ & $<0.01$ & $<0.01$ \\
\hline PRM & 0.82 & 0.02 & 0.00 & 1.00 & 0.92 & 0.00 & 0.00 & 0.00 & 0.00 & & 0.54 & 0.99 & 0.99 & $<0.01$ & $<0.01$ & $<0.01$ & 0.14 & $<0.01$ & $<0.01$ & $<0.01$ & $<0.01$ \\
\hline WCM & 0.69 & 0.00 & 0.00 & 0.82 & 0.74 & 0.03 & 0.03 & 0.00 & 0.00 & 0.03 & & 0.21 & 0.44 & $<0.01$ & $<0.01$ & $<0.01$ & 0.12 & $<0.01$ & $<0.01$ & $<0.01$ & $<0.01$ \\
\hline WPH & 0.82 & 0.03 & 0.00 & 1.00 & 0.92 & 0.00 & 0.00 & 0.00 & 0.00 & 0.00 & 0.03 & & 0.99 & $<0.01$ & $<0.01$ & $<0.01$ & 0.05 & $<0.01$ & $<0.01$ & $<0.01$ & $<0.01$ \\
\hline WMA & 0.82 & 0.02 & 0.00 & 1.00 & 0.92 & 0.00 & 0.00 & 0.00 & 0.00 & 0.00 & 0.03 & 0.00 & & $<0.01$ & $<0.01$ & $<0.01$ & 0.12 & $<0.01$ & $<0.01$ & $<0.01$ & $<0.01$ \\
\hline AAB & 0.59 & 0.75 & 0.76 & 0.67 & 0.60 & 0.80 & 0.80 & 0.76 & 0.76 & 0.80 & 0.71 & 0.80 & 0.80 & & 0.47 & 0.42 & $<0.01$ & $<0.01$ & 0.05 & 0.03 & $<0.01$ \\
\hline ARB & 0.62 & 0.77 & 0.78 & 0.71 & 0.64 & 0.83 & 0.83 & 0.78 & 0.78 & 0.83 & 0.74 & 0.83 & 0.83 & 0.00 & & 0.99 & $<0.01$ & $<0.01$ & 0.02 & $<0.01$ & $<0.01$ \\
\hline ASB & 0.63 & 0.80 & 0.81 & 0.75 & 0.67 & 0.86 & 0.86 & 0.81 & 0.81 & 0.86 & 0.76 & 0.86 & 0.86 & 0.00 & 0.00 & & $<0.01$ & $<0.01$ & 0.01 & 0.03 & $<0.01$ \\
\hline TNP & 0.65 & 0.05 & 0.05 & 0.75 & 0.68 & 0.10 & 0.10 & 0.05 & 0.05 & 0.10 & 0.03 & 0.10 & 0.10 & 0.68 & 0.70 & 0.72 & & $<0,01$ & $<0.01$ & $<0.01$ & $<0.01$ \\
\hline TMA & 0.86 & 0.93 & 0.96 & 1.00 & 0.95 & 1.00 & 1.00 & 0.96 & 0.96 & 1.00 & 0.92 & 1.00 & 1.00 & 0.84 & 0.86 & 0.89 & 0.86 & & $<0.01$ & $<0.01$ & $<0.01$ \\
\hline BMM & 0.33 & 0.66 & 0.65 & 0.40 & 0.34 & 0.73 & 0.73 & 0.65 & 0.65 & 0.73 & 0.59 & 0.73 & 0.73 & 0.10 & 0.12 & 0.13 & 0.56 & 0.79 & & 0.27 & $<0.01$ \\
\hline BMA & 0.37 & 0.57 & 0.57 & 0.41 & 0.35 & 0.61 & 0.61 & 0.57 & 0.57 & 0.61 & 0.52 & 0.62 & 0.61 & 0.09 & 0.09 & 0.11 & 0.51 & 0.66 & 0.02 & & $<0.01$ \\
\hline BOM & 0.07 & 0.53 & 0.52 & 0.36 & 0.31 & 0.56 & 0.56 & 0.52 & 0.52 & 0.56 & 0.48 & 0.57 & 0.56 & 0.33 & 0.35 & 0.36 & 0.47 & 0.61 & 0.13 & 0.19 & \\
\hline GTA & 0.57 & 0.73 & 0.73 & 0.65 & 0.58 & 0.77 & 0.77 & 0.73 & 0.73 & 0.77 & 0.69 & 0.78 & 0.77 & 0.61 & 0.63 & 0.64 & 0.66 & 0.81 & 0.47 & 0.43 & 0.41 \\
\hline GTT & 0.80 & 0.90 & 0.92 & 0.93 & 0.87 & 0.96 & 0.96 & 0.92 & 0.92 & 0.96 & 0.88 & 0.96 & 0.96 & 0.79 & 0.82 & 0.84 & 0.82 & 0.97 & 0.72 & 0.62 & 0.57 \\
\hline WCS & 0.36 & 0.56 & 0.55 & 0.39 & 0.33 & 0.59 & 0.59 & 0.55 & 0.55 & 0.59 & 0.51 & 0.60 & 0.59 & 0.44 & 0.46 & 0.47 & 0.50 & 0.64 & 0.25 & 0.27 & 0.24 \\
\hline NEL & 0.44 & 0.13 & 0.13 & 0.48 & 0.42 & 0.18 & 0.18 & 0.13 & 0.13 & 0.18 & 0.09 & 0.19 & 0.18 & 0.46 & 0.48 & 0.49 & 0.09 & 0.72 & 0.29 & 0.30 & 0.29 \\
\hline WMP & 0.69 & 0.01 & 0.00 & 0.82 & 0.74 & 0.06 & 0.06 & 0.00 & 0.00 & 0.06 & 0.00 & 0.06 & 0.06 & 0.71 & 0.74 & 0.76 & 0.04 & 0.92 & 0.58 & 0.52 & 0.48 \\
\hline AMB & 0.37 & 0.65 & 0.65 & 0.39 & 0.32 & 0.72 & 0.72 & 0.65 & 0.65 & 0.72 & 0.58 & 0.72 & 0.72 & 0.19 & 0.20 & 0.21 & 0.55 & 0.78 & 0.04 & 0.03 & 0.17 \\
\hline GMA & 0.59 & 0.75 & 0.76 & 0.68 & 0.61 & 0.80 & 0.80 & 0.76 & 0.76 & 0.80 & 0.72 & 0.81 & 0.80 & 0.62 & 0.65 & 0.66 & 0.68 & 0.84 & 0.48 & 0.45 & 0.42 \\
\hline GPA & 0.78 & 0.89 & 0.91 & 0.92 & 0.85 & 0.95 & 0.95 & 0.91 & 0.91 & 0.95 & 0.87 & 0.96 & 0.95 & 0.77 & 0.80 & 0.82 & 0.81 & 0.96 & 0.69 & 0.59 & 0.54 \\
\hline GPB & 0.78 & 0.89 & 0.91 & 0.92 & 0.85 & 0.95 & 0.95 & $\begin{array}{l}0.91 \\
\end{array}$ & 0.91 & 0.95 & 0.87 & 0.96 & 0.95 & 0.77 & 0.79 & 0.82 & 0.81 & 0.96 & 0.68 & 0.58 & 0.54 \\
\hline GWB & 0.43 & 0.64 & 0.64 & 0.49 & 0.42 & 0.68 & 0.68 & 0.64 & 0.64 & 0.68 & 0.59 & 0.69 & 0.68 & 0.51 & 0.54 & 0.55 & 0.57 & 0.73 & 0.33 & 0.34 & 0.30 \\
\hline
\end{tabular}




\section{Supplementary Table 4 continued...}

\begin{tabular}{|c|c|c|c|c|c|c|c|c|c|c|}
\hline & GTA & GTT & WCS & NEL & WMP & AMB & GMA & GPA & GPB & GWB \\
\hline BBO & $<0.01$ & $<0.01$ & $<0.01$ & $<0.01$ & $<0.01$ & $<0.01$ & $<0.01$ & $<0.01$ & $<0.01$ & $<0.01$ \\
\hline WCP & $<0.01$ & $<0.01$ & $<0.01$ & 0.01 & 0.44 & $<0.01$ & $<0.01$ & $<0.01$ & $<0.01$ & $<0.01$ \\
\hline CHM & $<0.01$ & $<0.01$ & $<0.01$ & $<0.01$ & 0.38 & $<0.01$ & $<0.01$ & $<0.01$ & $<0.01$ & $<0.01$ \\
\hline $\mathrm{CIO}$ & $<0.01$ & $<0.01$ & $<0.01$ & $<0.01$ & 0.01 & 0.02 & 0.01 & $<0.01$ & 0.01 & $<0.01$ \\
\hline CIW & $<0.01$ & $<0.01$ & $<0.01$ & $<0.01$ & $<0,01$ & $<0.01$ & $<0.01$ & $<0.01$ & $<0.01$ & 0.01 \\
\hline KKM & $<0.01$ & $<0.01$ & $<0.01$ & 0.01 & 0.26 & $<0.01$ & $<0.01$ & $<0.01$ & $<0.01$ & $<0.01$ \\
\hline KTM & $<0.01$ & $<0.01$ & $<0.01$ & $<0.01$ & 0.29 & $<0.01$ & $<0.01$ & $<0.01$ & $<0.01$ & $<0.01$ \\
\hline MBM & $<0.01$ & $<0.01$ & $<0.01$ & $<0.01$ & 0.31 & $<0.01$ & $<0.01$ & $<0.01$ & $<0.01$ & $<0.01$ \\
\hline PBM & $<0.01$ & $<0.01$ & $<0.01$ & $<0.01$ & 0.37 & $<0.01$ & $<0.01$ & $<0.01$ & $<0.01$ & $<0.01$ \\
\hline PRM & $<0.01$ & $<0.01$ & $<0.01$ & $<0.01$ & 0.26 & $<0.01$ & $<0.01$ & $<0.01$ & $<0.01$ & $<0.01$ \\
\hline WCM & $<0.01$ & $<0.01$ & $<0.01$ & 0.01 & 0.45 & $<0.01$ & $<0.01$ & $<0.01$ & $<0.01$ & $<0.01$ \\
\hline WPH & $<0.01$ & $<0.01$ & $<0.01$ & $<0.01$ & 0.19 & $<0.01$ & $<0.01$ & $<0.01$ & $<0.01$ & $<0.01$ \\
\hline WMA & $<0.01$ & $<0.01$ & $<0.01$ & $<0.01$ & 0.28 & $<0.01$ & $<0.01$ & $<0.01$ & $<0.01$ & $<0.01$ \\
\hline AAB & $<0.01$ & $<0.01$ & $<0.01$ & $<0.01$ & $<0.01$ & 0.03 & $<0.01$ & $<0.01$ & $<0.01$ & $<0.01$ \\
\hline ARB & $<0.01$ & $<0.01$ & $<0.01$ & $<0.01$ & $<0.01$ & $<0,01$ & $<0.01$ & $<0.01$ & $<0.01$ & $<0.01$ \\
\hline ASB & $<0.01$ & $<0.01$ & $<0.01$ & $<0.01$ & $<0.01$ & 0.04 & $<0.01$ & $<0.01$ & $<0.01$ & $<0.01$ \\
\hline TNP & $<0.01$ & $<0.01$ & $<0.01$ & 0.01 & 0.19 & $<0.01$ & $<0.01$ & $<0.01$ & $<0.01$ & $<0.01$ \\
\hline TMA & $<0.01$ & $<0.01$ & $<0.01$ & $<0.01$ & $<0.01$ & $<0.01$ & $<0.01$ & $<0.01$ & $<0.01$ & $<0.01$ \\
\hline BMM & $<0.01$ & $<0.01$ & $<0.01$ & $<0.01$ & $<0.01$ & 0.17 & $<0.01$ & $<0.01$ & $<0.01$ & $<0.01$ \\
\hline BMA & $<0.01$ & $<0.01$ & $<0.01$ & $<0.01$ & $<0.01$ & 0.13 & $<0.01$ & $<0.01$ & $<0.01$ & $<0.01$ \\
\hline $\mathrm{BOM}$ & $<0.01$ & $<0.01$ & $<0.01$ & $<0.01$ & $<0.01$ & $<0.01$ & $<0.01$ & $<0.01$ & $<0.01$ & $<0.01$ \\
\hline GTA & & $<0.01$ & $<0.01$ & $<0.01$ & $<0.01$ & $<0.01$ & $<0.01$ & $<0.01$ & $<0.01$ & $<0.01$ \\
\hline GTT & 0.77 & & $<0.01$ & $<0.01$ & $<0.01$ & $<0.01$ & 0.05 & $<0.01$ & $<0.01$ & $<0.01$ \\
\hline WCS & 0.44 & 0.45 & & $<0.01$ & $<0.01$ & $<0.01$ & $<0.01$ & $<0.01$ & $<0.01$ & 0.05 \\
\hline NEL & 0.50 & 0.67 & 0.33 & & 0.01 & $<0.01$ & $<0.01$ & $<0.01$ & $<0.01$ & $<0.01$ \\
\hline WMP & 0.69 & 0.88 & 0.50 & 0.09 & & $<0.01$ & $<0.01$ & $<0.01$ & $<0.01$ & $<0.01$ \\
\hline AMB & 0.46 & 0.71 & 0.25 & 0.29 & 0.57 & & $<0.01$ & $<0.01$ & $<0.01$ & $<0.01$ \\
\hline GMA & 0.62 & 0.06 & 0.25 & 0.51 & 0.71 & 0.47 & & $<0.01$ & $<0.01$ & 0.07 \\
\hline GPA & 0.75 & 0.92 & 0.33 & 0.65 & 0.87 & 0.68 & 0.76 & & 0.99 & $<0.01$ \\
\hline GPB & 0.75 & 0.92 & 0.33 & 0.64 & 0.87 & 0.67 & 0.76 & 0.00 & & $<0.01$ \\
\hline GWB & 0.51 & 0.28 & 0.06 & 0.39 & 0.59 & 0.32 & 0.08 & 0.52 & 0.52 & \\
\hline
\end{tabular}


Supplementary Table 5. Cominella virgata sample site pairwise differences calculated using genetic distance (below) and associated p-values (above).

\begin{tabular}{|c|c|c|c|c|c|c|c|c|c|c|c|c|c|c|c|c|c|c|c|c|c|c|}
\hline & AHV & BBV & KTV & MAV & MGV & NGV & PAV & PBV & PRV & WPB & WPH & WMP & AMB & $\mathrm{AAB}$ & ARB & ASB & BMM & BMA & BOM & GTA & NEL & MP \\
\hline AHV & & $<0.01$ & $<0.01$ & 0.99 & $<0.01$ & $<0.01$ & $<0.01$ & $<0.01$ & $<0.01$ & $<0.01$ & $<0.01$ & $<0.01$ & $<0.01$ & $<0.01$ & $<0.01$ & $<0.01$ & $<0.01$ & $<0.01$ & $<0.01$ & $<0.01$ & $<0.01$ & $<0.01$ \\
\hline BBV & 0.72 & & $<0.01$ & $<0.01$ & 0.10 & $<0.01$ & $<0.01$ & $<0.01$ & $<0.01$ & $<0.01$ & $<0.01$ & $<0.01$ & $<0.01$ & 0.05 & $<0.01$ & 0.01 & $<0.01$ & $<0.01$ & $<0.01$ & $<0.01$ & $<0.01$ & $<0.01$ \\
\hline KTV & 0.99 & 0.35 & & $<0.01$ & $<0.01$ & 0.02 & $<0.01$ & 0.99 & 0.99 & $<0.01$ & $<0.01$ & $<0.01$ & 0.99 & $<0.01$ & 0.43 & 0.99 & $<0.01$ & $<0.01$ & $<0.01$ & $<0.01$ & 0.99 & $<0.01$ \\
\hline MAV & 0.00 & 0.54 & 1.00 & & $<0.01$ & $<0.01$ & $<0.01$ & $<0.01$ & $<0.01$ & $<0.01$ & $<0.01$ & $<0.01$ & $<0.01$ & $<0.01$ & $<0.01$ & $<0.01$ & $<0.01$ & $<0.01$ & $<0.01$ & $<0.01$ & $<0.01$ & $<0.01$ \\
\hline MGV & 0.63 & 0.08 & 0.35 & 0.47 & & $<0.01$ & $<0.01$ & $<0.01$ & $<0.01$ & $<0.01$ & $<0.01$ & $<0.01$ & $<0.01$ & $<0.01$ & $<0.01$ & $<0.01$ & $<0.01$ & $<0.01$ & $<0.01$ & $<0.01$ & $<0.01$ & $<0.01$ \\
\hline NGV & 0.79 & 0.13 & 0.07 & 0.70 & 0.21 & & $<0.01$ & 0.01 & 0.02 & $<0.01$ & $<0.01$ & $<0.01$ & $<0.01$ & $<0.01$ & 0.04 & $<0.01$ & $<0.01$ & $<0.01$ & $<0.01$ & $\begin{array}{l}<01 \\
\end{array}$ & 0.01 & $<0.01$ \\
\hline PAV & 0.79 & 0.67 & 0.94 & 0.71 & 0.60 & 0.00 & & $<0.01$ & $<0.01$ & $<0.01$ & $<0.01$ & $<0.01$ & $<0.01$ & $<0.01$ & $<0.01$ & $<0.01$ & $<0.01$ & $<0.01$ & $<0.01$ & $<0.01$ & $<0.01$ & $<0.01$ \\
\hline PBV & 0.99 & 0.35 & 0.00 & 1.00 & 0.35 & 0.07 & 0.93 & & 0.99 & $<0.01$ & $<0.01$ & $<0.01$ & 0.99 & $<0.01$ & 0.42 & 0.99 & $<0.01$ & $<0.01$ & $<0.01$ & $<0.01$ & 0.99 & $<0.01$ \\
\hline PRV & 0.99 & 0.35 & 0.00 & 0.99 & 0.35 & 0.07 & 0.94 & 0.00 & & $<0.01$ & $<0.01$ & $<0.01$ & $\begin{array}{l}0.99 \\
\end{array}$ & $<0.01$ & 0.49 & 0.99 & $<0.01$ & $<0.01$ & $<0.01$ & $<0.01$ & 0.99 & $<0.01$ \\
\hline WPB & 0.99 & 0.46 & 1.00 & 1.00 & 0.41 & 0.55 & 0.94 & 1.00 & 1.00 & & 0.02 & 0.21 & $<0.01$ & $<0.01$ & $<0.01$ & $<0.01$ & $<0.01$ & $<0.01$ & $<0.01$ & $<0.01$ & $<0.01$ & $<0.01$ \\
\hline WPH & 0.72 & 0.24 & 0.51 & 0.62 & 0.29 & 0.31 & 0.68 & 0.51 & 0.51 & 0.18 & & 0.74 & $<0.01$ & $<0.01$ & $<0.01$ & $<0.01$ & $<0.01$ & $<0.01$ & $<0.01$ & $<0.01$ & $<0.01$ & $<0.01$ \\
\hline WMP & 0.79 & 0.28 & 0.57 & 0.71 & 0.31 & 0.34 & 0.75 & 0.57 & 0.57 & 0.10 & 0.00 & & $<0.01$ & $<0.01$ & $<0.01$ & $<0.01$ & $<0.01$ & $<0.01$ & $<0.01$ & $<0.01$ & $<0.01$ & $<0.01$ \\
\hline AMB & 0.99 & 0.39 & 0.00 & 1.00 & 0.39 & 0.09 & 0.94 & 0.00 & 0.00 & 1.00 & 0.54 & 0.60 & & $<0.01$ & 0.42 & 0.04 & $<0.01$ & $<0.01$ & $<0.01$ & $<0.01$ & 0.28 & $<0.01$ \\
\hline AAB & 0.59 & 0.13 & 0.41 & 0.46 & 0.20 & 0.25 & 0.61 & 0.41 & 0.41 & 0.51 & 0.36 & 0.39 & 0.44 & & $<0.01$ & $<0.01$ & $<0.01$ & $<0.01$ & $<0.01$ & $<0.01$ & $<0.01$ & $<0.01$ \\
\hline ARB & 0.97 & 0.34 & 0.01 & 0.96 & 0.36 & 0.06 & 0.92 & 0.01 & 0.01 & 0.91 & 0.48 & 0.53 & 0.02 & 0.41 & & 0.42 & $<0.01$ & $<0.01$ & $<0.01$ & $<0.01$ & 0.75 & $<0.01$ \\
\hline ASB & 0.97 & 0.35 & 0.00 & 0.96 & 0.37 & 0.07 & 0.92 & 0.00 & 0.00 & 0.92 & 0.51 & 0.56 & 0.00 & 0.42 & 0.01 & & $<0.01$ & $<0.01$ & $<0.01$ & $<0.01$ & 0.28 & $<0.01$ \\
\hline BMM & 0.94 & 0.64 & 0.88 & 0.92 & 0.58 & 0.70 & 0.91 & 0.88 & 0.88 & 0.88 & 0.67 & 0.71 & $\begin{array}{l}0.89 \\
\end{array}$ & 0.61 & 0.86 & 0.86 & & 0.03 & $<0.01$ & $<0.01$ & $<0.01$ & $<0.01$ \\
\hline BMA & 0.81 & 0.38 & 0.59 & 0.74 & 0.39 & 0.43 & 0.78 & 0.59 & 0.59 & 0.60 & 0.44 & 0.47 & 0.62 & 0.41 & 0.57 & 0.59 & 0.14 & & $<0.01$ & $<0.01$ & $<0.01$ & $<0.01$ \\
\hline BOM & 0.98 & 0.76 & 0.97 & 0.98 & 0.69 & 0.78 & 0.95 & 0.97 & 0.97 & 0.97 & 0.74 & 0.78 & 0.97 & 0.71 & 0.94 & 0.94 & 0.83 & 0.62 & & $<0.01$ & $<0.01$ & $<0.01$ \\
\hline GTA & 0.69 & 0.24 & 0.44 & 0.61 & 0.30 & 0.32 & 0.67 & 0.44 & 0.44 & 0.47 & 0.37 & 0.38 & 0.46 & 0.25 & 0.43 & 0.44 & 0.26 & 0.51 & 0.51 & & $<0.01$ & $<0.01$ \\
\hline NEL & 0.98 & 0.41 & 0.00 & 0.98 & 0.41 & 0.09 & 0.94 & 0.00 & 0.00 & 0.96 & 0.54 & 0.59 & 0.00 & 0.45 & 0.00 & 0.00 & 0.88 & 0.96 & 0.96 & 0.47 & & $<0.01$ \\
\hline MP & 0.99 & 0.53 & 1.00 & 1.00 & 0.47 & 0.60 & 0.93 & 1.00 & 1.00 & 1.00 & 0.55 & 0.62 & 0.46 & 0.52 & 0.93 & 0.93 & 0.69 & 0.85 & 0.85 & 0.27 & 0.97 & \\
\hline
\end{tabular}


Supplementary Table 6. Cominella virgata sample site pairwise differences calculated using haplotype frequencies (below) and associated pvalues (above).

\begin{tabular}{|c|c|c|c|c|c|c|c|c|c|c|c|c|c|c|c|c|c|c|c|c|c|c|}
\hline & AHV & BBV & KTV & MAV & MGV & NGV & PAV & PBV & PRV & WPB & WPH & WMP & AMB & $\mathrm{AAB}$ & ARB & ASB & BMM & BMA & BOM & GTA & NEL & MP \\
\hline AHV & & $<0.01$ & $<0.01$ & 0.99 & $<0.01$ & $<0.01$ & $<0.01$ & $<0.01$ & $<0.01$ & $<0.01$ & $<0.01$ & $<0.01$ & $<0.01$ & $<0.01$ & $<0.01$ & $<0.01$ & $<0.01$ & $<0.01$ & $<0.01$ & $<0.01$ & $<0.01$ & $<0.01$ \\
\hline BBV & 0.62 & & $<0.01$ & $<0.01$ & $<0.01$ & 0.05 & $<0.01$ & $<0.01$ & $<0.01$ & $<0.01$ & $<0.01$ & $<0.01$ & $<0.01$ & 0.02 & $<0.01$ & $<0.01$ & $<0.01$ & $<0.01$ & $<0.01$ & $<0.01$ & $<0.01$ & $<0.01$ \\
\hline KTV & 0.95 & .51 & & $<0.01$ & $<0.01$ & $<0.01$ & $<0.01$ & 0.99 & 0.99 & $<0.01$ & $<0.01$ & $<0.01$ & 0.99 & $<0.01$ & 0.58 & 0.13 & $<0.01$ & $<0.01$ & $<0.01$ & $<0.01$ & $<0.01$ & $<0.01$ \\
\hline MAV & 0.00 & 0.50 & 1.00 & & $<0.01$ & $<0.01$ & $<0.01$ & $<0.01$ & $<0.01$ & $<0.01$ & $<0.01$ & $<0.01$ & $<0.01$ & $<0.01$ & $<0.01$ & $<0.01$ & $<0.01$ & $<0.01$ & $<0.01$ & $<0.01$ & $<0.01$ & $<0.01$ \\
\hline MGV & 0.58 & 0.23 & 0.64 & 0.47 & & $<0.01$ & $<0.01$ & $<0.01$ & $<0.01$ & $<0.01$ & $<0.01$ & $<0.01$ & $<0.01$ & $<0.01$ & $<0.01$ & $<0.01$ & $<0.01$ & $<0.01$ & $<0.01$ & $<0.01$ & $<0.01$ & $<0.01$ \\
\hline NGV & 0.58 & 0.08 & 0.25 & 0.48 & 0.23 & & $<0.01$ & $<0.01$ & $<0.01$ & $<0.01$ & $<0.01$ & $<0.01$ & $<0.01$ & 0.02 & $<0.01$ & 0.04 & $<0.01$ & $<0.01$ & $<0.01$ & $<0.01$ & $<0.01$ & $<0.01$ \\
\hline PAV & 0.65 & 0.32 & 0.70 & 0.57 & 0.32 & 0.33 & & $<0.01$ & $<0.01$ & $<0.01$ & $<0.01$ & $<0.01$ & $<0.01$ & $<0.01$ & $<0.01$ & $<0.01$ & $<0.01$ & $<0.01$ & $<0.01$ & $<0.01$ & 0.01 & $<0.01$ \\
\hline PBV & 0.95 & 0.51 & 0.00 & 1.00 & 0.64 & 0.25 & 0.70 & & 0.99 & $<0.01$ & $<0.01$ & $<0.01$ & 0.99 & $<0.01$ & 0.54 & 0.14 & $<0.01$ & $<0.01$ & $<0.01$ & $<0.01$ & 0.99 & $<0.01$ \\
\hline PRV & 0.95 & 0.51 & 0.00 & 1.00 & 0.64 & 0.25 & 0.70 & 0.00 & & $<0.01$ & $<0.01$ & $<0.01$ & 0.99 & $<0.01$ & 0.51 & 0.12 & $<0.01$ & $<0.01$ & $<0.01$ & $<0.01$ & $<0.01$ & $<0.01$ \\
\hline WPB & 0.95 & 0.69 & 1.00 & 1.00 & 0.64 & 0.63 & 0.70 & 1.00 & 1.00 & & 0.03 & 0.18 & $<0.01$ & $<0.01$ & $<0.01$ & $<0.01$ & $<0.01$ & $<0.01$ & $<0.01$ & $<0.01$ & 0.07 & $<0.01$ \\
\hline WPH & 0.73 & 0.44 & 0.78 & 0.68 & 0.43 & 0.43 & 0.50 & 0.78 & 0.78 & 0.13 & & 0.86 & $<0.01$ & $<0.01$ & $<0.01$ & $<0.01$ & $<0.01$ & $<0.01$ & $<0.01$ & $<0.01$ & $<0.01$ & $<0.01$ \\
\hline WMP & 0.80 & 0.52 & 0.84 & 0.77 & 0.50 & 0.50 & 0.57 & 0.84 & 0.84 & 0.08 & 0.00 & & $<0.01$ & $<0.01$ & $<0.01$ & $<0.01$ & $<0.01$ & $<0.01$ & $<0.01$ & $<0.01$ & $<0.01$ & $<0.01$ \\
\hline AMB & 0.96 & 0.55 & 0.00 & 1.00 & 0.67 & 0.67 & 0.73 & 0.00 & 0.00 & 1.00 & 0.80 & 0.86 & & $<0.01$ & 0.16 & 0.02 & $<0.01$ & $<0.01$ & $<0.01$ & $<0.01$ & $<0.01$ & $<0.01$ \\
\hline AAB & 0.59 & 0.14 & 0.32 & 0.51 & 0.28 & 0.28 & 0.36 & 0.32 & 0.32 & 0.63 & 0.46 & 0.52 & 0.35 & & $<0.01$ & 0.01 & $<0.01$ & $<0.01$ & $<0.01$ & $<0.01$ & $<0.01$ & $<0.01$ \\
\hline ARB & 0.87 & 0.40 & 0.01 & 0.87 & 0.57 & 0.57 & 0.63 & 0.01 & 0.01 & 0.91 & 0.70 & 0.76 & 0.02 & 0.24 & & 0.63 & $<0.01$ & $<0.01$ & $<0.01$ & $<0.01$ & $<0.01$ & $<0.01$ \\
\hline ASB & 0.79 & 0.29 & 0.05 & 0.76 & 0.48 & 0.48 & 0.55 & 0.05 & 0.05 & 0.83 & 0.64 & 0.70 & 0.07 & 0.17 & 0.00 & & $<0.01$ & $<0.01$ & $<0.01$ & $<0.01$ & $<0.01$ & $<0.01$ \\
\hline BMM & 0.85 & 0.60 & 0.89 & 0.84 & 0.57 & 0.57 & 0.63 & 0.89 & 0.89 & 0.89 & 0.70 & 0.76 & 0.90 & 0.58 & 0.82 & 0.75 & & $<0.01$ & $<0.01$ & $<0.01$ & $<0.01$ & $<0.01$ \\
\hline BMA & 0.61 & 0.29 & 0.64 & 0.53 & 0.30 & 0.30 & 0.38 & 0.64 & 0.64 & 0.65 & 0.47 & 0.53 & 0.66 & 0.32 & 0.57 & 0.50 & 0.17 & & $<0.01$ & $<0.01$ & $<0.01$ & $<0.01$ \\
\hline BOM & 0.90 & 0.71 & 0.94 & 0.92 & 0.67 & 0.67 & 0.72 & 0.94 & 0.94 & 0.94 & 0.78 & 0.83 & 0.94 & 0.66 & 0.88 & 0.82 & 0.869 & 0.67 & & $<0.01$ & 0.99 & $<0.01$ \\
\hline GTA & 0.50 & 0.18 & 0.46 & 0.43 & 0.22 & 0.22 & 0.30 & 0.46 & 0.46 & 0.53 & 0.39 & 0.44 & 0.48 & 0.21 & 0.41 & 0.35 & 0.28 & 0.11 & 0.56 & & 0.99 & $<0.01$ \\
\hline NEL & 0.92 & 0.94 & 0.71 & 0.26 & 0.51 & 0.65 & 0.04 & 0.00 & 0.03 & 0.00 & 0.87 & 0.92 & 0.65 & 0.47 & 0.95 & 0.77 & 0.96 & 0.83 & 0.00 & 0.00 & & $<0.01$ \\
\hline MP & 0.94 & 0.60 & 1.00 & 1.00 & 0.56 & 0.56 & 0.64 & 1.00 & 1.00 & 1.00 & 0.73 & 0.81 & 1.00 & 0.57 & 0.89 & 0.79 & 0.86 & 0.59 & 0.92 & 0.39 & 1.00 & \\
\hline
\end{tabular}

